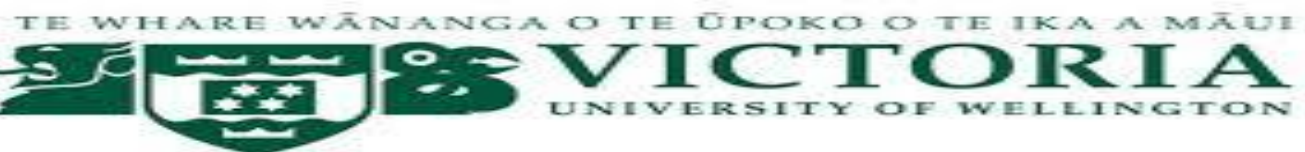

\title{
The Decentralisation of Australia's Gender Equality and Women's Empowerment Strategy in Oro Province, Papua New Guinea.
}

By

\section{Camilla Ethel Angoro}

\begin{abstract}
A thesis submitted to Victoria University of Wellington in partial fulfilment of requirements for the degree of Master of Development Studies
\end{abstract}

March 2018

School of Geography, Environment and Earth Sciences Victoria University of Wellington 



\section{Dedication}

This thesis is dedicated to my two beautiful children; Ashley Jane Angoro-Kuvi and Matui Leonard Angoro-Kuvi. Thank you for your patience in allowing me to pursue postgraduate studies. With all my love - mum. 


\section{Acknowledgements}

I would like to thank the following who have been instrumental in this study and towards the completion of this thesis:

Firstly, to God for giving me wisdom and understanding in times of doubt as I journeyed as a postgraduate student.

Secondly, to all the research participants, whose voices are captured in this thesis, I thank you for your time: DFAT officials in PNG; PNG government officials both in Waigani and in Oro Provincial Administration; the Oro Provincial Council of Women President; and Popondetta Urban LLG -Ward 10 Council of Women.

Thirdly, to my supervisors, Professor John Overton and Dr Luke Kiddle for their continuous academic support throughout this thesis journey. Their ongoing critical assessment of my work has immensely helped in the quality of my thesis.

Fourthly, to MFAT, under the NZ Aid Scholarship Programme, for allowing me to pursue post-graduate studies and for the financial help throughout the duration of my study in Victoria University of Wellington.

On a more personal note, I would like to extend my thanks and appreciation to my uncle Dr Martyn Reynolds and aunt Sylvia Reynolds for their never-ending support during my thesis journey; Wendy Davidson for providing spiritual guidance; and my cousin Vivian Gegera-Willy for ensuring I had family in Aotearoa, New Zealand. To all the PNG wantoks of Victoria University of Wellington who have become more than friends, especially my susa Lydia Imara for being my go-to person when life got me down. My course mates in the Development Studies class of 2017 for just willing to listen and help me get through this thesis journey.

Penultimately, but nowhere near the least, to my parents, Blake Angoro Snr and Muriel Angoro, siblings, aunt Prismaude Konari for supporting me by caring for my children while I undertook studies, and aunt Rose Tovivi and family at Sorovi for housing me for two weeks of my field work in Popondetta. And finally, to my two beautiful children, Ashley Jane Angoro-Kuvi and Matui Leonard Angoro-Kuvi, for being patient and understanding in allowing me to complete my studies.

Thank you all! 


\begin{abstract}
Women's empowerment is the most recent approach to women in development. The inclusion of women's empowerment in development policies has recently gained traction in Papua New Guinea (PNG). However, the effectiveness of such policies has been questioned in its efforts to support local women to improve their lives. This study was undertaken to understand Australia's Official Development Assistance (ODA) to PNG in terms of the contribution of the Department of Foreign Affairs and Trade (DFAT) to supporting women's empowerment in Oro province through the implementation of its Gender Equality and Women's Empowerment Strategy 2016.

With the huge gender inequality gap in PNG and the rise in Gender-Based Violence (GBV), women's empowerment is an approach that can contribute to helping local women improve their lives. The purpose of this study was to understand the trickle-down effect of Australia's ODA to subnational organisations in PNG, and its contributions to women's empowerment in Oro province. The study used a qualitative approach involving policy document reviews and interviews with research participants.

The key findings from this study show that there is no direct support to local women's organisations in Oro province either from DFAT or the PNG government; there are some issues with implementation and ownership of DFAT's Gender Equality and Women's Empowerment Strategy and the PNG government's gender policies in Oro province; and that women's coalitions can be a vehicle for change in local communities in Oro province.

This study offers benefits to DFAT programmes in PNG, and to national government agencies tasked to review their gender policies; as well as the Oro Provincial Administration; the Oro Provincial Government; and the Oro Provincial Council of Women.

The study suggests topics for further research. It also suggests that DFAT's Gender Equality and Women's Empowerment Strategy, and its associated funding have the potential to improve women's lives in Oro province and PNG more broadly.
\end{abstract}




\section{Table of Contents}

Dedication. i

Acknowledgements .........................................................................................................................ii

Abstract .............................................................................................................................................................iii

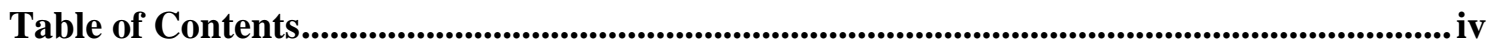

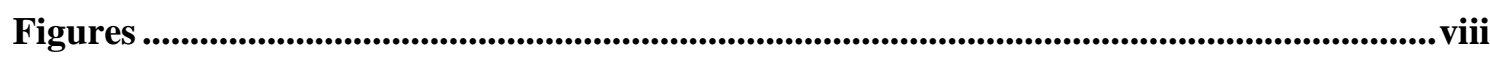

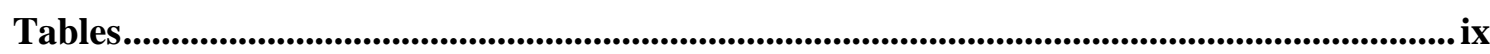

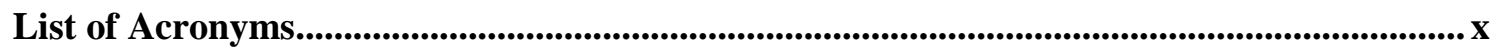

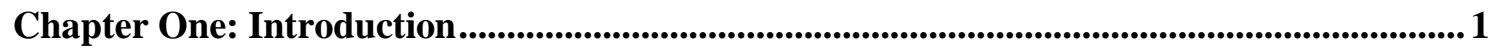

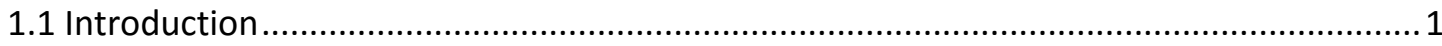

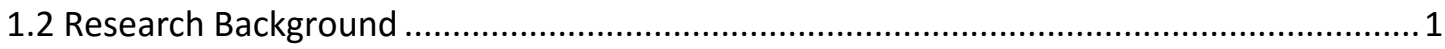

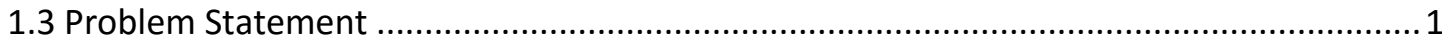

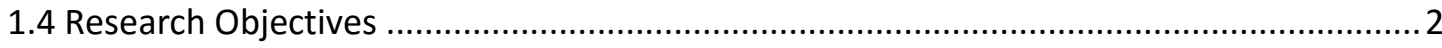

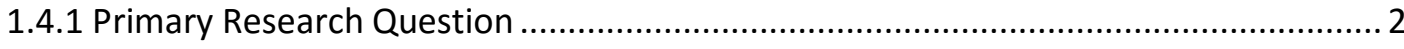

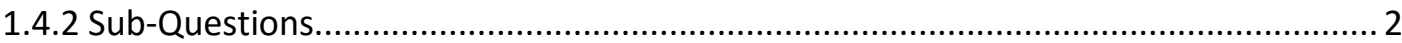

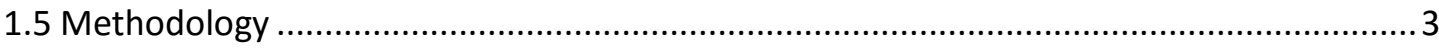

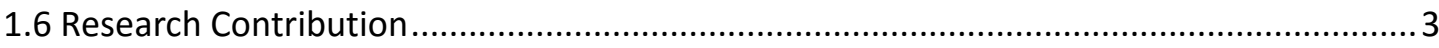

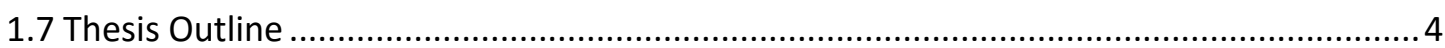

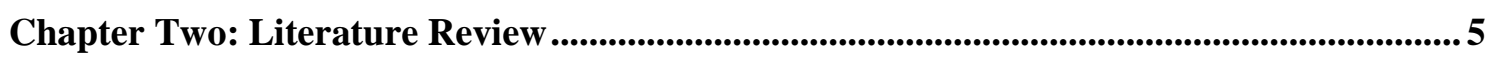

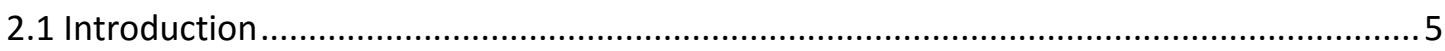

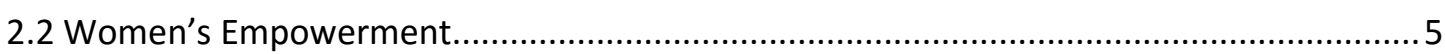

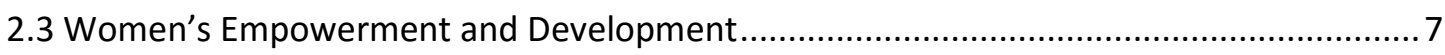

2.3.1 Challenges with Implementation of WID and GAD Policies ...................................... 7

2.3.2 Disconnection between Policy Implementation and Intention of Gender Policies ..... 9

2.3.3 Australian Aid and Gender/Women's Empowerment ............................................. 11

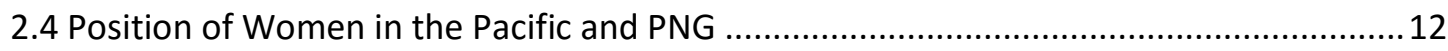

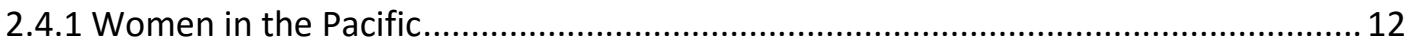

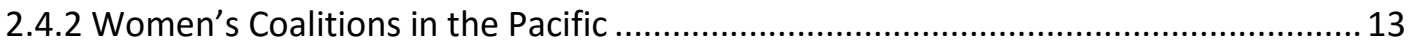

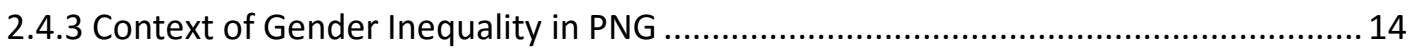

2.4.4 Impacts of Gender Inequality Experienced by Women in PNG ................................ 15

2.4.5 Support by Churches towards Women's Empowerment .......................................... 17

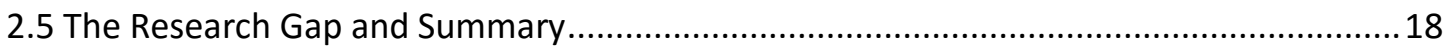

Chapter Three: Context of Gender and Women's Empowerment in PNG ........................... 20

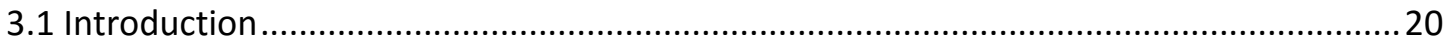

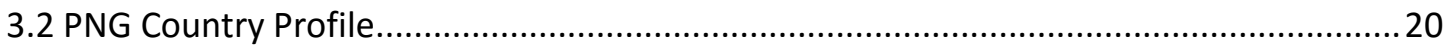

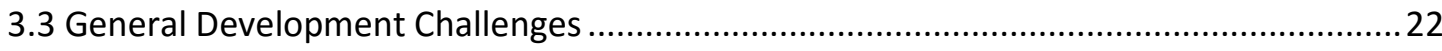

Camilla Ethel Angoro - Master's Thesis - Victoria University of Wellington 
3.3.1 Gender-Specific Development Challenges.................................................23

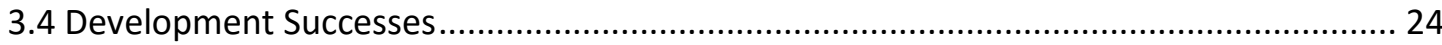

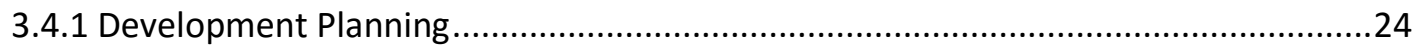

3.5 The Context of Women's Empowerment .......................................................... 25

3.5.1 PNG Government Support to Women's Empowerment ....................................26

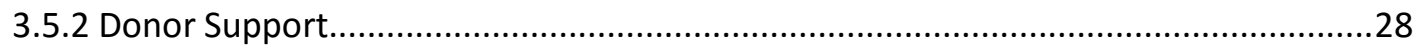

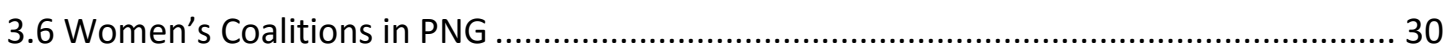

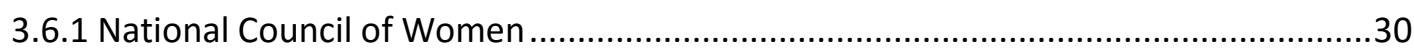

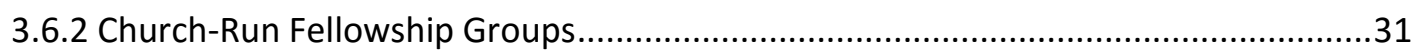

3.6.3 Examples of Community-Led Women's Groups ...............................................31

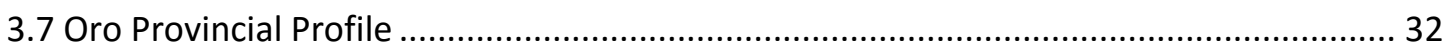

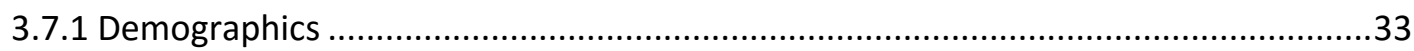

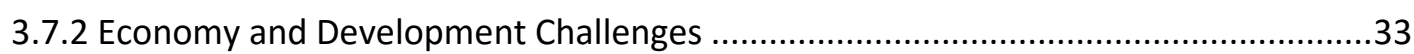

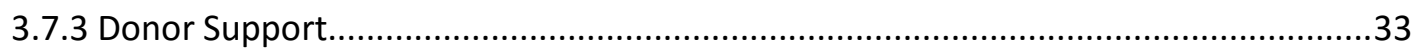

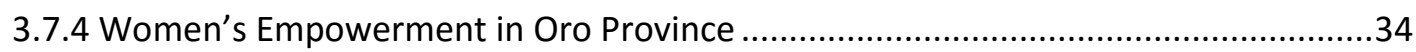

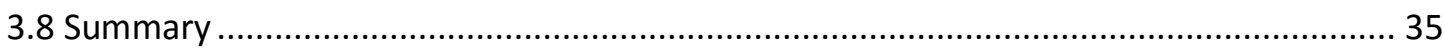

Chapter Four: Methodology ..................................................................................36

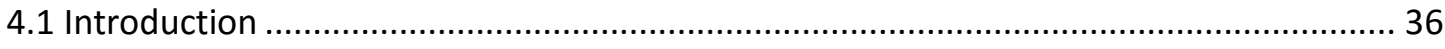

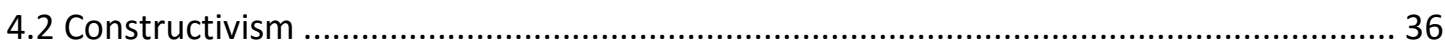

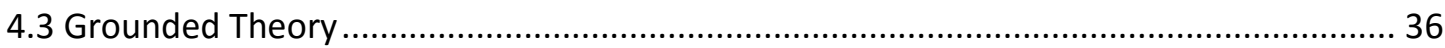

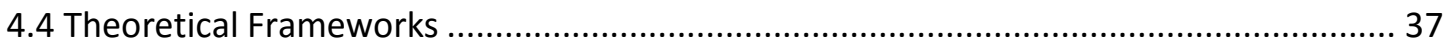

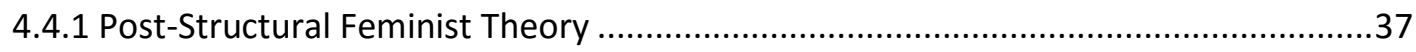

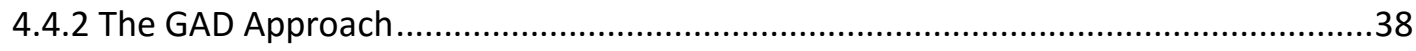

4.4.3 Women's Empowerment Framework ............................................................39

4.4.4 Summary of Attributes of All Theoretical Frameworks ......................................40

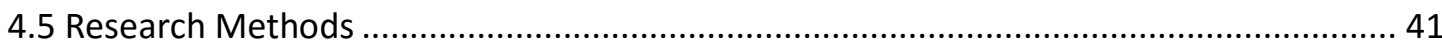

4.5.1 Participant Selection ...........................................................................41

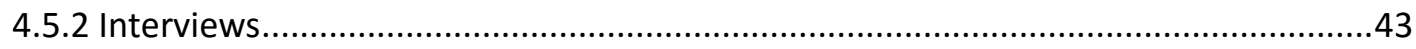

4.5.3 Semi-Structured Interviews and Focus Group Discussion ...................................43

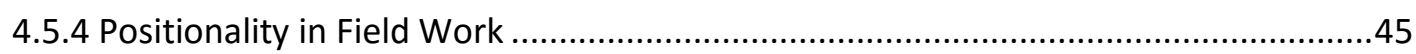

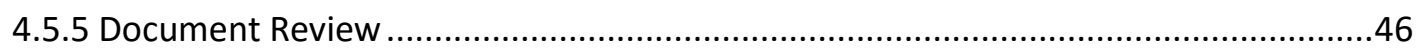

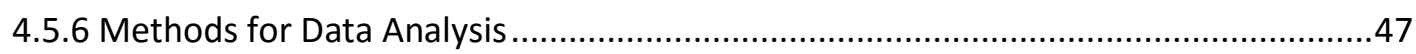

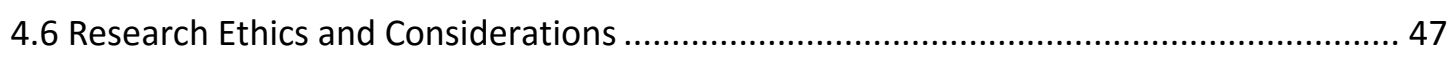

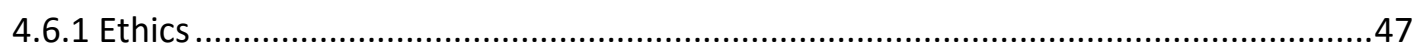

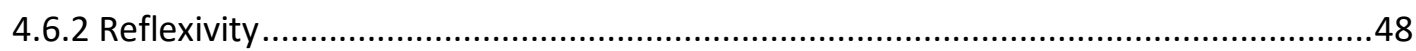

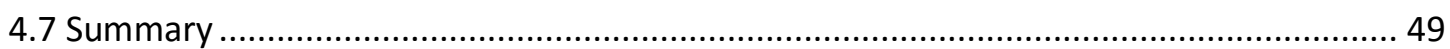


Chapter Five: Key Results Showing DFAT and PNG Government's Support to Women's

Empowerment in PNG ........................................................................................................................5 50

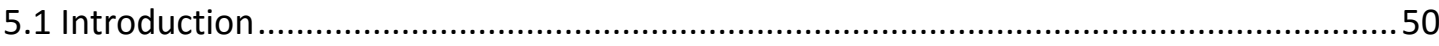

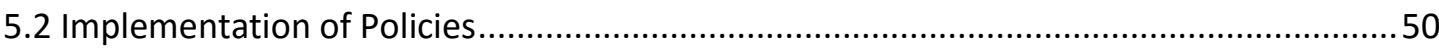

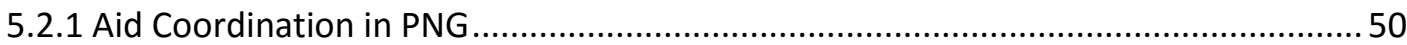

5.2.2 National Policy for Women and Gender Equality 2011-15 …................................. 52

5.2.3 Gender Equality and Social Inclusion Policy 2013-15 _................................................. 53

5.24 Australia's DFAT Gender Equality and Women's Empowerment Strategy ..................55

5.2.5 DFAT's Gender Equality and Women's Empowerment Strategy Implemented in

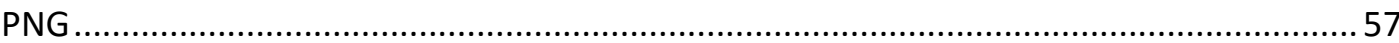

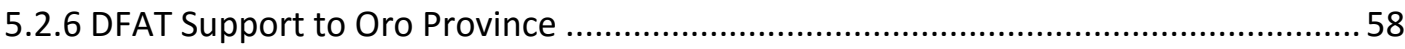

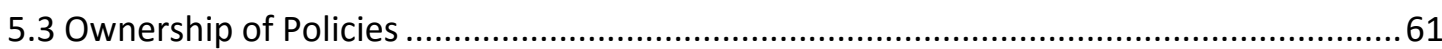

5.3.1 DFAT Gender and Women's Empowerment Strategy in PNG ....................................61

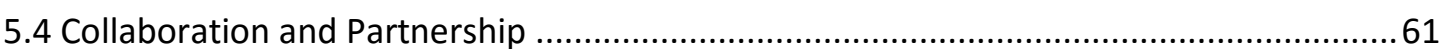

5.4.1 The National Policy for Women and Gender Equality ............................................62

5.4.2 DFAT Programmes to Work Collaboratively in Oro Province ......................................62 62

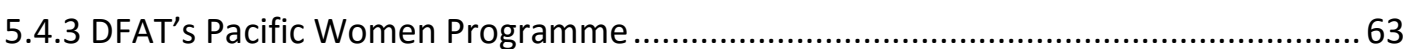

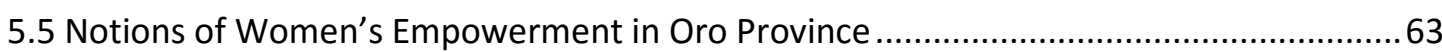

5.5.1 Targeted Training for Women to Sustain Women's Empowerment Efforts ................64

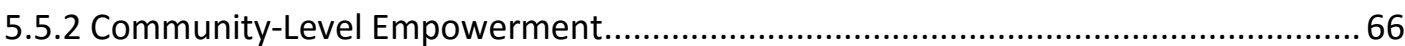

5.5.3 Local Women's Organisations as Vehicles for Change ................................................68

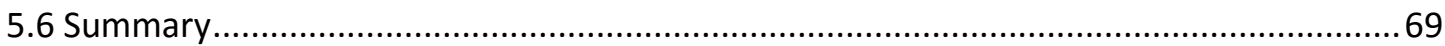

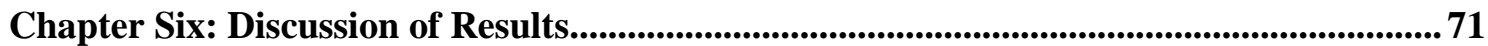

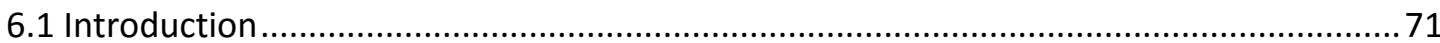

6.2 Implementation of Gender Policies at Subnational Level ............................................. 71

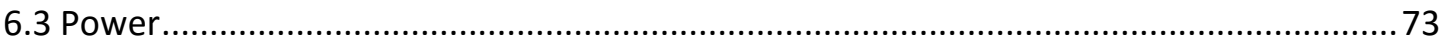

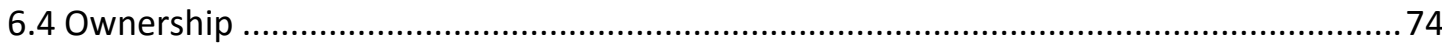

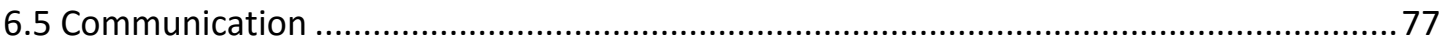

6.6 Working in Collaboration and through Partnerships .....................................................79

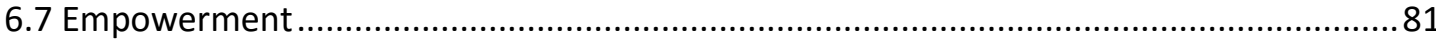

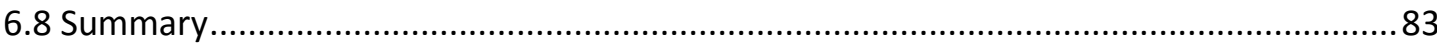

Chapter Seven: Conclusion .............................................................................................................................8 84

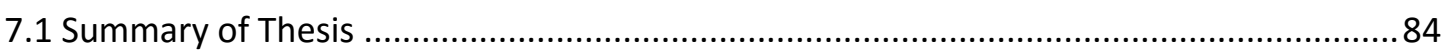

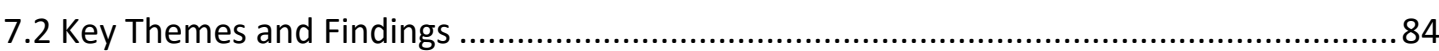

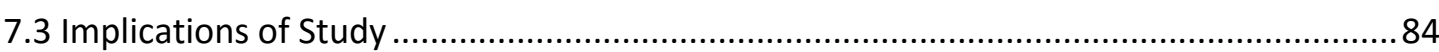

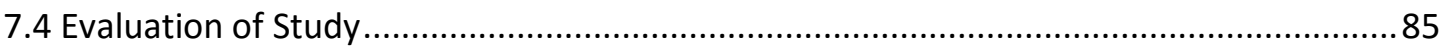

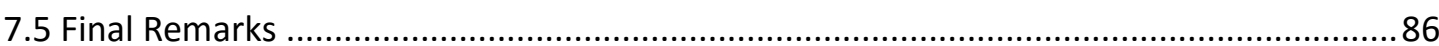

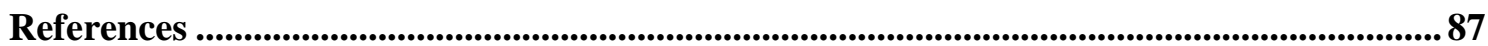


Appendices. 


\section{Figures}

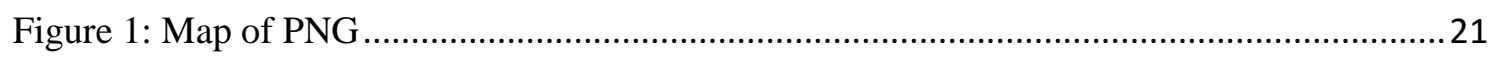

Figure 2: Map of Oro (Northern) Province (including Sohe and Ijivitari Districts)....... 32

Figure 3: Diagram Showing the Interconnectedness of Theoretical Frameworks..... 41 


\section{Tables}

Table 1: Summary of Attributes for All Three Theoretical Frameworks . .40

Table 2: Table of Interview Participants by Gender, Date and Agency. 44 


\section{List of Acronyms}

ARB Autonomous Region of Bougainville

BWF Bougainville Women's Federation

CEDAW Convention on the Elimination of All Forms of Discrimination Against Women

CGA Country Gender Assessment

CPI Corruption Perception Index

CPP Church Partnership Program

CW Council of Women

DFAT Department of Foreign Affairs and Trade (Australia)

DNPM Department of National Planning and Monitoring

DPM Department of Personnel Management

DSP Development Strategic Plan

GAD Gender and Development

GBV Gender-Based Violence

GDI Gender Development Index

GESI Gender Equality and Social Inclusion

GII Gender Inequality Index

HDI Human Development Index

JSS4D Justice Services and Stability for Development

KI Kokoda Initiative

KWP Kuk Women for Peace

LLG Local-Level Government

MDG Millennium Development Goals

MTDP Medium Term Development Plan

NCD National Capital District

NCW National Council of Women

NGO Non-Governmental Organisation

ODA Official Development Assistance

OECD Organisation for Economic Cooperation and Development

OPA Oro Provincial Administration 


$\begin{array}{ll}\text { PFA } & \text { Platform for Action } \\ \text { PGF } & \text { PNG Governance Facility } \\ \text { PGK } & \text { Papua New Guinea Kina } \\ \text { PIC } & \text { Pacific Island Country or Pacific Island Countries } \\ \text { PIF } & \text { Pacific Island Forum } \\ \text { PLGP } & \text { Provincial and Local-level Government Programme } \\ \text { PNG } & \text { Papua New Guinea } \\ \text { SDG } & \text { Sustainable Development Goals } \\ \text { UN } & \text { United Nations } \\ \text { VHV } & \text { Village Health Volunteers } \\ \text { WB } & \text { World Bank } \\ \text { WID } & \text { Women In Development } \\ \text { YWCA } & \text { Young Women's Christian Association }\end{array}$





\section{Chapter One: Introduction}

\subsection{Introduction}

This thesis looks at the decentralisation of Australia-DFAT's Gender Equality and Women's Empowerment Strategy 2016 in Oro province, PNG. This chapter will focus on the background of the study, highlight the problem statement, identify the research objectives, outline the methodology used, identify the research contribution, and provide an outline of the thesis.

\subsection{Research Background}

A general interest in gender/women's empowerment and development has been strong globally for the past two to three decades. This has been evident through the inclusion of gender in goal number three of the Millennium Development Goals (MDG) and goal number five in the Sustainable Development Goals (SDG). Aid donors have also taken a strong interest in the inclusion of gender and women's empowerment in the way they provide Official Development Assistance (ODA) to recipient countries. Understanding the uses of development aid in PNG, and its contributions to addressing issues of gender inequality and women's empowerment, can aid to identify synergies, innovative ways and work collaboratively with the recipient government to support women at subnational level. This study specifically looks at the relationship between Australia's DFAT and the PNG government, and their support for women's empowerment in Oro province. Using DFAT's Gender Equality and Women's Empowerment Strategy 2016 as a basis, this thesis seeks to understand how support was drawn from the relevant policy document to support women's empowerment initiatives in PNG, particularly at the subnational level in Oro province. Without entirely focusing on DFAT, the study also looks at the PNG government's key gender policies and their implementation in Oro province.

\subsection{Problem Statement}

With the high gender inequality gap between men and women, and the rise in GenderBased Violence (GBV) being a serious development and social challenge in PNG, it is important to understand the issues and challenges faced by women, and develop ways to combat these issues by providing support to women in rural areas of PNG. One way of doing this is by supporting women's empowerment initiatives through local women's 
coalitions/organisations. Women's coalitions are a vehicle for change for women in rural areas.

\subsection{Research Objectives}

Given that PNG has been a recipient of donor assistance from Australia for many years, it was important to find out if the trickle-down effect of this donor assistance has reached rural women after all these years of support. The research objectives were to understand the contributions of DFAT's Gender Equality and Women's Empowerment Strategy in supporting women's empowerment in Oro province.

\subsubsection{Primary Research Question}

The primary research question that this study endeavoured to investigate was:

How does DFAT's Gender Equality and Women's Empowerment Strategy 2016 contribute to the empowerment of women in Oro province?

The research aims to map how Australia's ODA is used in PNG, and how it is channelled through its DFAT's Gender Equality and Women's Empowerment Strategy 2016 to support local women in Oro province. This has the potential to indicate the effectiveness of the trickle-down effect of Australia's ODA to PNG at a subnational level. Generally, such support is focused at national level as the implementing mechanisms of donor programmes do not necessarily allow for easy flow to subnational levels.

\subsubsection{Sub-Questions}

The sub questions that were used to support the key question were:

- What was the level of collaboration between DFAT and the PNG government to implement DFAT's Gender Equality and Women's Empowerment Strategy?

Without entirely focusing on the support from DFAT, it is also important to understand the level of collaboration with the PNG government in terms of implementing the DFAT Strategy in PNG.

- What were the contributions of the PNG government officials and local politicians in implementing women's empowerment initiatives in Oro province? 
Without entirely being dependent on development aid, it is vital that the PNG government takes ownership of their gender and women's empowerment issues at subnational level.

- How does DFAT's Gender Equality and Women's Empowerment Strategy support the work of women's organisations in Oro province?

Women's organisations, such as the National Council of Women (NCW) through its branch the Oro Provincial Council of Women, have existed in the Oro province for many years. The Oro Provincial Council of Women has struggled to maintain its office and support rural women, due to funding and resource constraints. Could DFAT's Gender Equality and Women's Empowerment Policy be used to support this organisation or other local women's organisations in Oro province?

\subsection{Methodology}

This study uses a qualitative research approach that involves research participants through semi-structured interviews. It also reviews documents of key PNG gender policies, as well as the DFAT's Gender Equality and Women's Empowerment Strategy. As suggested by Eyben (2008), discourse is not only limited to policy documents, written or said, but also procedures and activities associated with the words that shape whose knowledge counts, and also what alternatives are proposed and recognised as possible. The document reviews will be focused around the implementation of policies and strategies, and the progress to date in terms of achieving intended objectives and outcomes.

\subsection{Research Contribution}

The rationale of the study is to understand the context of women's empowerment at subnational level, specifically in Oro province, and the support given by DFAT and the PNG government towards women's empowerment efforts. The motivation for this study is to give something back to my people of Oro province, especially to help rural women in their endeavours to better their lives. It is hoped that this study can contribute to PNG's gender policies in light of upcoming reviews; the inclusion of gender and women's empowerment initiatives in the Oro Provincial Development and Corporate Plans, Sohe and Ijivitari District Plans; and finally to highlight to DFAT the need for an in-country 
(PNG) implementation strategy/framework of the Gender Equality and Women's Empowerment Strategy 2016 to assist DFAT programmes to maximise their efforts in light of gender and women's empowerment.

\subsection{Thesis Outline}

This thesis is organised into chapters and subsections within those chapters. Chapter One provides an introduction to the study and the thesis. Chapter Two highlights the literature review carried out in light of the topic of international aid, and specifically gender equality and women's empowerment within specific developing counties, the Pacific region and PNG. Chapter Three looks at the context of gender equality and women's empowerment in PNG. Chapter Four provides the methodology used in this research. Chapter Five describes the findings of this study. Chapter Six offers a discussion of the key findings that emerged from the analysis. And, finally, Chapter Seven provides a conclusion to the whole thesis. A reference list and appendices of key documents follow. 


\section{Chapter Two: Literature Review}

\subsection{Introduction}

This research is centred on donor support to women's empowerment in a developing country. This chapter covers relevant literature and is organised into the following sections: gender and women's empowerment; development aid and women's empowerment; the position of women in the Pacific; and the literature gap regarding women's empowerment in the Pacific and PNG. This arrangement of sections is generally in line with the topics that my research questions cover.

\subsection{Women's Empowerment}

The World Bank defines empowerment as the process of enhancing the capacity of individuals or groups to make choices and to transform those choices into desired actions and outcomes (World Bank, 2011). Another definition from Cornwall and Rivas (2015) is, "empowerment is fundamentally about changing power relations; it is not about improving women's capacity to cope with situations in which they experience oppression or injustice. It is about enabling women to question what they might previously have considered 'normal' and to begin to act to change that reality" (p. 405). The issue of power is a factor when it comes to the empowerment of women in PNG. Unfortunately, women do not always have power in society and within family units to be able to make important decisions about their lives, and therefore they are vulnerable to many issues and even subject to abuse.

Bishop and Bowman (2014) write that the notion of empowerment can be both challenging and an inspiring concept. Empowerment can be deeply challenging from a measurement perspective. Having carried out evaluations for Oxfam Great Britain (GB), Bishop and Bowman argue that the "understandings and definitions of women's empowerment should necessarily drive the measurement approach" (2014, p.255). Similar sentiments around challenges in measuring women's empowerment have been previously identified by feminist activists and gender and development practitioners, notably through the works of Kabeer (1999). Kabeer writes about women's empowerment being a process by which those who have been denied the ability to make strategic life's choices acquire such ability. In designing a practical approach to evaluating Oxfam GB's women's empowerment programme, Bishop and Bowman (2014) identified that there were issues around definition. For example, should empowerment be defined as a process, 
a state of being, something that is externally defined, or should it be defined by the women that the programme supports? Similar issues could be faced by any women's empowerment programme, whether it be driven by donors or recipient governments. Programme teams have to be mindful to design practical approaches to address this issue. In the example from Oxfam GB, they addressed this issue by working with the organisation's leadership team, the central evaluation team (made up of independent evaluators and members of Oxfam GB's Monitoring and Evaluation team) and reviewed all existing tools, research and inputs from gender advisers (Bishop \& Bowman, 2014).

Around the 1980s and 1990s there was increasing recognition of the inequalities of power between men and women, especially in developing countries. This prompted development experts to start conversations around how they could address these inequalities, and get women's rights fully into the development agenda (Cornwall \& Rivas, 2015). There were a number of movements or phases in feminist discussions of development: Women in Development (WID); Women and Development (WAD); Gender and Development (GAD); Women, Environment and Development (WED); and Postmodernism and Development (PAD); as indicated by Peet and Hartwick (2009). However, for this literature review, I will only be making references to WID and GAD, as these are most relevant for the programmes examined in PNG.

In 1970, Esther Boserup critiqued the idea of modernisation, suggesting that it had excluded women, but indicated that economic efficiency and modern planning could emancipate women in the Third World. She argued that enlightened policies for national governments and international agencies could address this issue (Boserup, 1970, as cited in Peet \& Hartwick, 2009). Her reflections and work contributed to the birth of WID. The "WID approach recognised that women were active participants in the development process, who through both their productive and reproductive roles, provided a critical, if often unacknowledged, contribution to economic growth" (Moser, 1993, p. 63). However, there have been critics of the WID approach. For example, they claim that development practitioners tend to represent Third World women as backward, vulnerable and in need of help from First World women (Peet \& Hartwick, 2009). Furthermore, as argued by Parpart and Marchand "WID discourse has generally fostered development practices that ignore difference(s), indigenous knowledge(s) and local practices, while legitimising foreign solutions to women's problems in the south" (1995, p. 16). In PNG, this argument could hold true for local women as development practitioners through aid programmes 
try to push their agendas onto local communities without fully understanding cultural norms and traditions. Following on from the WID policy, was the GAD policy. GAD differed from WID in its conceptualization of the sexual division of labour. Development was seen to be inclusive of gender relations rather just being women only (Peet \& Hartwick, 2009). The GAD approach maintains that to focus on women in isolation is to ignore the real problem which remains their subordinate status to men. As such, women cannot be viewed in isolation; a focus on gender relations is needed (Moser, 1993).

WID and GAD have increased awareness of the importance of women's empowerment. However, it seems this wave of support emerged largely from First World women. Hence, it is arguable whether they truly represented women from the Third World, and whether their notions of empowerment genuinely were reflective of women in developing countries. Cornwall and Rivas additionally argue that "gender equality and women's empowerment are frames that have led feminist activists into a cul-de-sac and away from a broader based alliance of social change activists. Both have been reduced to buzzwords that garland policy discourses in which there is little or nothing of the clamour for equality or equity that was once so powerful a part of the gender agenda" (2015, p. 397). Cornwall and Rivas (2015) also write about feminists and civil society organisations challenging the discourses of empowerment and gender within the framework of the MDGs. It is still unclear how these concepts in the MDGs have acquired their meaning. Even calls for a rights-based approach to women's empowerment and gender equality have been elaborated without deconstructing many of the assumptions inherent in how these concepts are discussed and invoked.

\subsection{Women's Empowerment and Development}

\subsubsection{Challenges with Implementation of WID and GAD Policies}

GAD policies are not implemented in a vacuum and they tend to depend upon general aid and development policies. Generally, changes in gender and development have always largely been shaped by changes in aid and development policies (Molyneux \& Razavi, 2005; Moser, 1993; Razavi \& Miller, 1995). It is of utmost importance to see how gender issues have been, and are being, handled in the context of aid reform processes. As indicated by Campbell and Teghtsoonian (2010), aid effectiveness is intended to assist recipient governments; however, the onus is on the state to channel these funds to support women. In a country such as PNG, where corruption is relatively high, this could potentially raise issues around accountability and raise questions whether such donor 
support does trickle down to PNG women in rural areas. According to Transparency International (2018), PNG had a Corruption Perception Index (CPI) score $^{1}$ of 29 out of 100 in year 2017 and 28 out of 100 in year 2016. These rankings put PNG in the category of countries with a high corruption rate and is ranked 135 out of 180 countries.

From the 1970s onwards, gender and participatory dimensions of development were increasingly recognised as important (Riddle, 2007). It was a period of learning for donors too. Rathgeber (1995) describes, for example, that donors generally struggled with women's empowerment initiatives. Donors sometimes lacked insight into local contexts including specific localised gender distributions. It is sometimes challenging for development agencies to appropriately localise WID and GAD policies. For example, as noted by Schech (1998), a Vietnamese feminist economist pointed out that the notion of gender equality, as used by international development agencies operating in Vietnam, not only lacked equivalent words in the Vietnamese language, but it also clashed with cultural constructions of women as different from men. She further pointed out that becoming the same as men is seen to require women to give up their own gendered identity. Therefore, it is important that the translations and understandings of gender and women's empowerment policies from donors or development agencies are clearly understood and accepted by local communities in recipient countries. Failing to do so could add further confusion and conflict with their cultures around gender norms.

The strong focus on women's human rights was also given impetus by the Fourth World Conference on Women held in Beijing in 1995. It sent a clear message to governments that respecting cultural differences must not become a fig leaf for condoning traditional, customary or modern practices that violate women's human rights (Schech \& McNally, 2001). However, Okin indicates that "this danger remains, and even well-meaning development workers may find it tempting to water down gender and development goals in their projects so as not to offend partner governments' and counterpart institutions' sensibilities" (1998, p. 36). This example highlights some situations that donors can be faced with. While trying to encourage 'ownership' as per the Paris Declaration, donors could potentially lose focus of their initial priorities, such as their gender agenda. Recipient governments' priorities can also override that of donors. However, another

\footnotetext{
1 This index ranks 180 countries and territories by their perceived levels of public sector corruption according to experts and businesspeople, uses a scale of 0 to 100 , where 0 is highly corrupt and 100 is very clean.
} 
view could be seen, for example Schech and McNally (2001) highlight the example of the Australian Aid programme officer in Vietnam who said that "imposing our gender policy on Vietnamese people could mean that the donor's ways are better than the recipients of the project" (p.663).

\subsubsection{Disconnection between Policy Implementation and Intention of Gender Policies}

It is evident that there is still often a disconnect between donors' gender policies and practice, as locally relevant on the ground. As highlighted by Holvoet and Inberg (2012), within the text of the 2005 Paris Declaration, gender issues are largely absent with only one passing reference to gender equality. The 2008 Accra Agenda for Action (3rd High Level Forum on Aid Effectiveness, 2008) and the 2011 Busan Partnership for Effective Development Cooperation (4th High Level Forum on Aid Effectiveness, 2011) devote slightly more attention to gender equality, but without really integrating a full gender dimension through the documents. Existing research about the actual degree of gender sensitivity in the implementation of the Paris Declaration has mainly focused on the recipients' side of the reform agenda (see Holvoet, 2010; Van Reisen \& Ussar, 2005; Whitehead, 2002; Zukerman \& Garrett, 2003). While a focus on recipient governments reflects the shift in responsibilities propagated under the Paris Declaration, studies of how donors are dealing with gender concerns in the era of the Paris Declaration are also relevant and needed.

Within recipient countries there may be instances of neglect of local gender policies if emphasis is only given to the donor funded gender policies/programmes. There has to be an element of collaboration to realise the efforts of both the donor and recipient governments to address gender inequality in a given country in a locally-appropriate way. On ownership, as per the Paris Declaration, the belief is that support and alignment with country-owned and country-led policies and processes avoid de-contextualised donor interventions and increase the probability of effective implementation and results. National policies, programmes and systems are to be put in place to stimulate gender equality and empowerment (Holvoet \& Inberg, 2012). However, while most partner countries do have national gender policies in place, these are neglected in their national poverty reduction policies, sector policies and plans (Holvoet, 2010; Zukerman \& Garett, 2003). 
Gender has now become an integral development policy and practice of Western and international development agencies. It is often a key cross-cutting issue for development intervention. However, a greater awareness of cultural differences in gender relations has also complicated policy formulation and implementation. Overall, a better understanding of locally specific gender relations is still required. At the same time and somewhat ironically, gender mainstreaming has been accompanied by a move away from specialist gender units in development organisations (Schech, 1998).

The study by Grown, Addison \& Tarp (2016) looked at the lessons and challenges for aid for gender equality. One of the findings was that donors should move away from characterising gender as a 'cross-cutting' issue, as this approach means it is less likely to be addressed systematically across all domains where gaps exist between men and women. The study recommended that an approach that directs country strategies, programmes and projects to concrete gender-related results in partner countries is likely to be more successful. The study also highlighted that gender data gaps at the national and subnational level are large impediments to assessing and monitoring aid effectiveness. "With the Sustainable Development Goals (SDG) now in place, and the heightened attention that is given to gender equality and female empowerment in these goals, more action from donors and partner countries will be expected. But to be effective, and have impact at scale, this action must be informed by high-quality research that yields recommendations for practical action" (Grown et al., 2016, p. 318). Also, in a recent study regarding public policy implementation and action in the Pacific (Vanuatu, Solomon Islands and Samoa), Aiafi (2017) highlights the need to have society's voice present in the formulation of public policies within Pacific Island Countries (PIC). He emphasises the need to have local home-grown policies emerging from local people: “...the 'genesis' or 'aetiology' of public policy is not rooted or built from within the context it is meant (or espoused) to impact" (p. 460).

Overall, the translation of gender awareness into effective practice has not been an easy task for donors and recipient countries. Moser (1993) also argues that women and gender remain marginalised in planning, theory and practice, and will do so until such time as feminist concerns are adequately incorporated into development policy and planning frameworks. This, perhaps, remains a work in progress. 


\subsubsection{Australian Aid and Gender/Women's Empowerment}

Narrowing down the focus to a specific donor, in this section I will focus on the Australian government's support through the Australian Department of Foreign Affairs and Trade (DFAT). DFAT is responsible for managing Australia's international aid programme within Australia and abroad since the integration from the former AusAID. Australia is a major donor in the Pacific: "Aid, its myriad forms, is the cornerstone of Australia's engagement with the Pacific" (Hawksley, 2009, p.115). Australia contributes to the Pacific region for historical and diplomatic reasons. One such example would be its support to PNG. PNG has had a close relationship with Australia for many years throughout its colonial history spanning back to 1905 when PNG was a separate territory of Australia. Today, PNG is a major recipient of Australian aid, with Australia being the largest bilateral donor in the country. In the financial year of 2015-16, PNG received an estimated Official Development Assistance (ODA) of AUD \$549.7 million (PGK 1.3 billion) from Australia (Department of Foreign Affairs and Trade, 2016).

In the 1990s most organisations, whether non-governmental, governmental or multilateral, claimed commitment to a WID or GAD approach. However, there is increasing debate in the literature regarding the legitimacy of imposing 'outside ideas', such as 'gender equality' or 'women's empowerment' on developing societies. The debate can lead to the risk of treating cultural differences in gender relations as fixed, or on the other hand the risk of treating the issue of gender as if all women in the world share a common experience of gender inequality. As highlighted by Nussbaum (1995) and Narayan (1998), WID and GAD policies by their nature are general policy statements, and in theory they are based on assumptions that all women tend to be discriminated against by the developmental process. In practice, donors/development experts are expected to take cultural differences in the recipient country into account when implementing such culturally sensitive policy. DFAT is no different, as highlighted by the then Australian Development Agency (AusAID) in 1997: "goals and priorities of tackling gender equality will vary from country to country [and] should be sensitive to the specific needs and priorities of developing country partners (AusAID, 1997, p. 4).

According to Hunt (1996), the then AusAID WID Policy compared favourably among other donors in stressing equality and systematic disadvantages, but its implementation lacked transparency, and thus raised the issue of accountability. As highlighted by Schech, “AusAID's WID policy and practice did have some conflicting trends; the quest 
to integrate women throughout the development program; the link between efficiency and equality; and the tolerance of cultural differences - are not only connected but are indicative of deep-seated contradictions which underpin the modernist development project of which WID is part of" (1998, p. 395).

As Schech and McNally (2001) indicated in the research carried out on the gender policy of Australian development projects in Vietnam, the policy was geared more to the knowledge requirements of development experts from overseas and lacked understanding of local gender relations in a rapidly changing environment. They also highlighted that the focus on partnership in contemporary development discourse gives the impression of equality and shared visions between international development organisations and their partner organisations in Vietnam in ways that might understate the extent to which these visions are, in fact, quite different.

\subsection{Position of Women in the Pacific and PNG}

\subsubsection{Women in the Pacific}

Gender relations and the status of women differ across the Pacific region, indicating the diversity of the region. Many factors influence women's status and the situations they experience. Most Pacific societies are patrilineal, which contributes to women's status and influence. Notably, it was found that that status of women was generally higher in Polynesia than in Melanesia (Lewis, 1998). According to a United Nations (UN) Report, focusing on the Pacific by Leslie Clark in 2014, progress towards greater gender equality over the preceding decade was very slow, despite many millions of dollars being spent, and commitments to gender equality through a range of national and regional plans, declarations and international conventions.

In Melanesia, the statistics for female representation in national parliaments do not compare well to other Pacific sub-regions (Polynesia and Micronesia). As explained by Spark and Corbett: "Explanations for the extraordinarily low levels of female representation in Melanesian countries typically emphasize structural barriers to participation: the absence of parties, the cost of campaigning and patriarchal norms" (2016, p. 12). The literature depicts an image of Melanesian women as passive and powerless; unable to overcome the "endemic opposition that stymies their participation" (Spark \& Corbett, 2016, p.12). This negative portrayal of Melanesian women creates impediments to fostering positive change for women's empowerment in Melanesian 
society. Another view expressed by Bhagwan-Rolls (2011) is that women in the Pacific require livelihood projects such as improved roads and access to water but they also need time and space to participate in the political process. Political involvement not just at the national level but also at local level governments such as district-level and village-level committees: "They need to be able to find their voice and the strength to address the status quo and engender discussions about the future. Their economic security is inextricably linked to their political security" (Bhagwan-Rolls, 2011, p.572).

The Beijing Platform for Action (PFA) is a global declaration for the empowerment of women and girls. "The Beijing Declaration and Platform for Action of 1995 is a visionary agenda for the empowerment of women. It still remains today the most comprehensive global policy framework and blueprint for action, and is a current source of guidance and inspiration to realize gender equality and the human rights of women and girls, everywhere" (United Nations, 1995, p, 3). The Pacific region has also signed up to this declaration like other regions of the world. A review of the Beijing PFA in the Pacific region in 2000 indicated that the preceding decade had seen significant progress in moving towards greater gender equity. The review also concluded that while the climate for gender equality has improved, efforts to build greater awareness must be intensified until changes are filtered through all social institutions. It was also noted that there was still need for the integration of gender issues in key policy and planning documents (House, 2000).

There is evidence of political support from leaders to enable the work of women's empowerment in the Pacific region. In 2012, leaders representing small island nations of the Pacific signed a document called the 'Pacific Leaders Gender Equality Declaration' that articulated explicit commitments to progress gender equality across a range of areas including economic empowerment. This commitment saw state leaders (almost all male in the Pacific) acknowledge the need for respective governments to join an international community united to address gender inequality and discrimination (McKinnon, Carnegie, Gibson \& Rowland, 2016).

\subsubsection{Women's Coalitions in the Pacific}

Women's coalitions/organisations have played a vital role for women in the Pacific. Dickson-Waiko (2003) highlights the work of Church-led fellowship groups in the Pacific that stand as an institution for women to seek support and empowerment. Christian 
churches have also contributed to women's empowerment through formal education and training as well as the provision of health services (Anderson, 2015). One important study by Fletcher, Brimacombe and Roche (2016) on behalf of DFAT's Pacific Women programme has looked at women's coalitions in four Pacific Island Countries (PIC) focussing on coalitions and their collective action on gender and power relations. Factors that were important in the formation and functioning of these coalitions were formative events, shared purpose, forms of leadership and nature of ownership. Some of the findings were that, consistently across all five case studies, formative events played a crucial role in the formation of new or existing organisations, such as a national crisis, a personal experience or organised opportunities. These women's organisations were able to capitalise on these events to form coalitions to address women's issues. Alignment of interest enabled coalitions to increase their support base and their influence; their leadership style shifted from an individual style to a more negotiated form of leadership; while local ownership was more widely acclaimed but difficult to define given their geographical proximity of their locality (for example: within communities and villages of the case study areas), which gave no guarantee of shared values and interests within the dimensions of power and gender relations.

\subsubsection{Context of Gender Inequality in PNG}

Overall, various complex factors relating to entrenched power relations and unwillingness, particularly among men, to alter social relations and the division of labour mean that equipping individual women with a good education, while a start, is not enough to challenge gender inequality in PNG. "An understanding of gender issues from a feminist perspective introduces questions of power, control of resources, and conflict which are potentially challenging and certainly difficult to deal with. Development practices tend to shy away from the complexities and challenges preferring instead their simple principles; and methodological tools" (Harris, 1995, as cited by Appleford, 2000, p.84). It is time to examine the simple principle that educating PNG women enhances the status of women. As Brouwer, Harris, and Tanaka (1998), editors of a World Bank (WB) report on gender in PNG, wrote: "the development of a sustained commitment to gender sensitive policies and programs cannot take place unless there are major shifts in attitudes and practices at all levels of government, non-government and community administration, and within families and households" (p.37). Overall, there is more to be done by those in 
authority both at national and subnational levels to institutionalise gender and women's empowerment initiatives, programmes and strategies.

\subsubsection{Impacts of Gender Inequality Experienced by Women in PNG}

With increasing issues surrounding gender inequality in PNG, very little attention has been given to understanding the contextual factors that influence women's coping mechanisms affecting their health and well-being. As argued by Hilton and Earnest (2010), government, civil society, and other stakeholders must build on, and learn from, each other. They should systematically engage in long-term local initiatives and with organisations that are driving socio-economic change and promoting social justice in their communities. Overall, women's groups in communities, such as the Lus Prut Mama in West New Britain (WNB) province, Kup Women in Peace in Simbu province and Young Women's Christian Association (YWCA), are vital vehicles for driving change and fostering sustainable empowerment for local women (Garap, 2004). Hilton and Ernest (2010) write that widespread gender inequality leaves women and girls particularly vulnerable to abuse, exploitation, and violence in PNG. Similarly, other scholars have highlighted the problems of gender in PNG in recent times (Howes, Ilave, Plana \& Femli PNG, 2017; Lamprell \& Braithwaite, 2017). These authors provide extensive analysis of the myriad interconnections between traditional cultures, modernity, gendered personhood, and sexual antagonism, in all their modern forms. In just one specific example, female advocates in PNG and wider Melanesia increasingly argue that traditional practices such as bride price payments are oppressive and reinforce widespread expectation of patriarchal dominance and male control over women (Jolly, 2000). While the practice of bride price is being seen negatively, this cannot be assumed to be the perspective of all Melanesians and Papua New Guineans. There are also positive aspects of practicing such cultural traditions. For example, bride price payment can help to foster new relationships by acknowledging the bride's family for their support in raising the bride. Historically, bride price was based on a fair exchange of gifts between families and clans. For example: the AreAre clan in Vanuatu used the concept of bride price to describe the release and exchange of a girl from one family, clan or community to another. It was traditionally paid so that an alliance would be forged and secured between the bride and grooms' families (United Nations, 2009). 


\subsubsection{Challenges in Tertiary Education}

As highlighted by Spark (2010), even tertiary educated PNG women continue to face multiple barriers and challenges. The study highlighted the following problems: male jealousy and anxiety about educated women as competitors (both at home and in the workplace); female jealousy and suspicion about educated women's opportunity and morality; active discrimination against educated women, including in relation to promotion, and in relation to the provision of accommodation and opportunities for further studies; the absence of formal child care; and culturally entrenched notions about women's roles. Another study by Yawi (2012), found that women in PNG entering tertiary education within PNG and abroad are faced with barriers imposed by a maledominated society, socio-cultural and socio-economic constraints that challenge their sense of self as women from PNG.

\subsubsection{Gender-Based Violence}

Women and girls in PNG are often marginalised and challenged. In PNG, the rate of GBV has reached high levels with more than two-thirds of PNG women experiencing GBV. GBV has sometimes been referred to as an 'epidemic' (Howes, et al., 2017, p. 67). A Non-Governmental Organisation (NGO) called Femli PNG was established in 2013 to support the case management of GBV survivors in accessing services such as courts, police, safe houses and medical attention (Howes, et al., 2017). However, GBV still remains a significant development and social challenge in PNG. As a result of this, in 2016 the government of PNG launched its National Strategy to Prevent and Respond to Gender Based Violence (2016-25). This policy aims to "strengthen and institutionalize the work of GBV in order to achieve zero tolerance towards GBV as per the Papua New Guinea Vision 2050" (Department of Community Development, 2016, p. 15). It is hoped that this policy can help address GBV more systematically within the government system and with service providers that help GBV survivors.

\subsubsection{Sorcery-related killings}

In recent times, sorcery-related killings against women have risen in PNG. In 2013, the torture and murder of the 20-year old Lepari Leniata brought attention to sorcery-related killing in PNG and prompted a bill to be passed in Parliament. Lepari's death received national and international press coverage and prompted the formation of Women Arise, a group led by PNG female human rights activists (Fletcher, et al., 2016). Another view shared by Auka, Gore and Koralyo (2015) states that "where a woman is suspected of 
being a sorcerer and is subjected to acts of torture, violence or even death, these matters are rarely brought to court or followed up in any investigations to result in legal proceedings. This unfortunately is consistent with the widely held view that women are less influential in the PNG community than men" (p. 252).

\subsubsection{Support by Churches towards Women's Empowerment}

In PNG, Christian churches have played a strong role in supporting the efforts around gender and women's empowerment. Church women's groups have been a support network for many women who have sought shelter for spiritual and emotional support when confronted with gender related issues and GBV. The Church Partnership Program (CPP) funded by Australian aid (now DFAT) highlights some positive work done by these churches. CPP works with the mainline churches in PNG, including the Anglican Church of PNG. The Anglican Church, for example, has made significant progress in formalising a church-wide strategy response with endorsement of a gender policy in 2010 (Anderson, 2015). Overall, women's church groups in PNG have been regarded as the catalyst for women's activism and an evolving grassroots feminism (Dickson-Waiko, 2003; Douglas, 2003). While churches may appear unlikely agents for gender justice, there is evidence that incremental steps, utilising subtle strategies, are being taken to challenge normative gender roles, to re-image what these might be, and also to empower women (Anderson, 2015). These churches are translating the gender agenda into a local Christian register because gender work is gradually being seen as a key component of the churches' practice of holistic human development that has the vision of enabling people to experience life in all its fullness (Anderson, 2015). In addition to church-led specific gender policies, equally important is the perspective that gender champions, especially males, are needed from within religious traditions to raise awareness and promote change (SheerattanBisnauth \& Peacock, 2010). However, there are also concerns that engagement may lead to the uncritical adoption of the dominant (usually male) perspectives within religious traditions. This could produce a further marginalisation of other perspectives, including gender-equal interpretations within those religious traditions, which may jeopardise progress that has been made towards gender equality (Pearson \& Tomalin, 2008). 


\subsection{The Research Gap and Summary}

From the literature discussed above, it is indicative that there are areas that need further research - especially in the PNG context. In particular, there are three areas regarding women's empowerment that would benefit from focused research:

1. Research at the subnational level is lacking even though most of PNG's population is rural-based. A lack of rural-specific research has led to the generalisation of gender and women's empowerment issues in PNG. Specific focus is needed on particular areas such as provinces, districts and Local-Level Governments (LLGs) so that local solutions can be identified to address issues. This could contribute to sustainability and help with the institutionalisation of the government's gender plans and strategies at the local level.

2. Another area that needs focus is how development aid has contributed to women's empowerment in PNG. This could look at all development agencies in PNG, or focus on a certain donor. PNG has been a recipient of development aid, but research does not adequately show how much of that support trickles down to rural village-based PNG women. It is also important to not just restrict focus to development partners such as donors but the government as well. Further research should aim to capture the PNG government's contributions to women's empowerment. This could give a clearer indication of what each government sector is doing to contribute to women's empowerment in PNG.

3. Finally, another area requiring research is the work of women's coalition groups in terms of how they support women's empowerment from the national to grass roots level. Data could form an avenue to support organisations to drive the improvement of the status of women in PNG.

In summary, this literature review indicates that the area of gender equality and women's empowerment needs to be further researched in the Pacific and specifically in PNG. It should be noted that most of the current literature is dominated by outsiders' perspectives and/or written by people not of Pacific or PNG origins, although Dickson-Waiko and Garap are exceptions. While the views of outsiders can make a contribution, this needs to be balanced by the output of more researchers/writers who are natives/nationals so that perspectives on issues around women's empowerment more clearly reflect local sensibilities. In addition, much gender policies in PNG seem to be based on the wider 
WID ideas; which seek to economically integrate women, in a similar approach to that taken in the previous MDGs. Deeper issues such as GBV require a GAD approach. Leading on from the literature review, I will now introduce my next chapter, which is the context of gender and women's empowerment in PNG. 


\section{Chapter Three: Context of Gender and Women's Empowerment in PNG}

\subsection{Introduction}

Given the discussion in the previous chapter, which raised issues regarding the way global theories and policies relate to specific cultural contexts, it is necessary to consider the specific cultural and policy context of PNG. In this chapter, I will present general information about PNG, describe its development challenges and successes, and discuss challenges that women face around gender and women's empowerment at national and at subnational level, specifically highlighting Oro province.

\subsection{PNG Country Profile}

PNG is the largest country in the Pacific region. It has a land mass of approximately $463,000 \mathrm{~km}^{2}$ (including the larger islands of New Britain, New Ireland, and Bougainville). PNG's topography presents great challenges for development as most of the population live in remote rural areas, which makes them more inaccessible for services and opportunities for development. PNG has a growing population of 7.278 million according to the last national census in 2011. This was an increase of just over 2 million people since the previous census in 2000 , at a growth rate of 2.9 per cent per annum. Today, this population figure is estimated to have increased to 7.9 million $^{2}$ with an increasingly youthful population. The life expectancy has improved to $67^{3}$ years in 2014, from 63 in 2000. However, the areas of child and maternal health, HIV/AIDS and accessibility to basic health facilities still remain a particular challenge.

PNG is not progressing well as per the 2016 United Nations Human Development Report for PNG. In 2015, it ranked 154 out of 188 countries in the Human Development Index (HDI); a rank it shares with Zimbabwe in Africa. PNG's HDI value was 0.156 which puts the country in a low development category.

\footnotetext{
${ }^{2}$ World Bank - http://www.worldbank.org/en/country/png/overview

${ }^{3}$ Department of National Planning and Monitoring - PNG MDG Progress Report 2015 


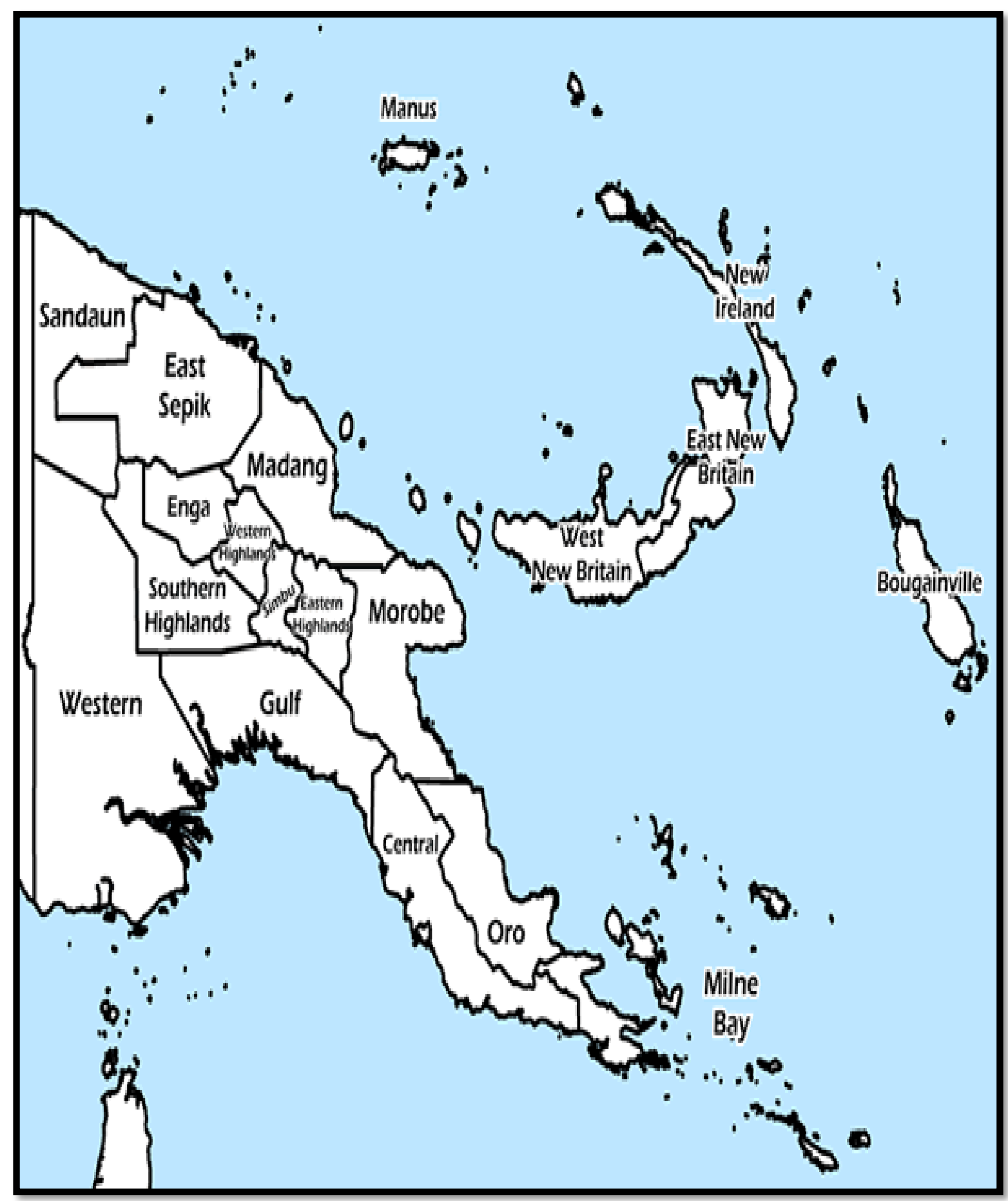

Source: Summer Institute of Linguistics of Papua New Guinea 
PNG is culturally diverse with over 800 languages. More than eighty percent of PNG's population live in rural areas within related tribal and language groups. This rural population are mostly engaged in subsistence farming and fishing. There are twenty-two (22) provinces with the inclusion of the Autonomous Region of Bougainville (ARB) and the National Capital District (NCD). PNG has vast natural resources such as gold, copper, oil, Liquefied Natural Gas (LNG), forest and marine resources. These natural resources are foundations of wealth creation for the country. PNG is home to many endangered flora and fauna which are constantly under increasing pressure from mining, logging, fishing and agricultural activities.

\subsection{General Development Challenges}

PNG's geography (large island size, scattered islands and huge population) and diversity (many ethnic groups and languages) contribute to a set of unique development challenges, especially in providing services to a scatted rural population. PNG has also failed to meet certain aspects of international commitments such as the MDGs ${ }^{4}$. In 2000, PNG signed up to this declaration but progress reports within the fifteen-year implementation period indicated that targets in maternal health, infant mortality, literacy and HIV/AIDs were not met (United Nations, 2010). This could be attributed to the remoteness of most of PNG's population, coupled with failing health and education systems. Fryatt, Mills and Nordstrom (2010) indicate that weak health systems are fundamental constraints to making progress towards the health MDGs in low-income countries. That could be a contributing factor to PNG not meeting some MDG targets.

PNG also faces the threats of global warming and climate change like other island nations in the world and in the Pacific region. The Office of Climate Change has developed the National Climate Compatible Development Management Policy 2014 that endeavours to address climate change issues in PNG. Climate change is likely to "exacerbate eventdriven hazards such as coastal flooding, inland flooding and landslides, and may also introduce new hazards due to gradual shifts in climatic conditions - most prominently, further malaria penetration into the highlands, changed agricultural yields and damaged coral reefs" (Office of Climate Change and Development, 2014, p.38).

Climate change effects indicated in the policy were: coastal flooding and rise in sea level affecting coastal regions; malaria severely affecting the population; and inland flooding,

\footnotetext{
${ }^{4}$ The MDGs have now been replaced by the Sustainable Development Goals (SDG)
} 
driven by heavy irregular rainfalls, regularly affecting valleys and wetlands in both lowlands and highlands. Other climate change effects include the rise in sea temperature and acidification destroying coral reefs over time (the coral triangle that surrounds PNG is known as the global centre of marine biodiversity); and landslides, triggered by increased rainfall intensity and land use changes, destroying vital assets in mountainous areas. Agricultural yields in the highlands region are particularly sensitive to changes in climatic conditions. For example, climate-sensitive crops such as sweet potato, coffee, tea and cocoa could be affected by the changes in climate affecting people's food supply and livelihood (Office of Climate Change and Development, 2014).

Even though PNG has experienced a decade of comparatively robust economic growth driven by high international prices for its exports and construction of a major LNG project, economic growth (Total Real Gross Domestic Product) fell from 11.8 per cent in 2015 to a projected 2.2 per cent in 2016 due to declining international commodity prices. The reduced revenue places PNG's fiscal position under pressure (Department of Treasury, 2016). The balance of payment difficulties could continue for the immediate future and place added pressure on PNG's budget, with cuts already made to core government services.

\subsubsection{Gender-Specific Development Challenges}

The Constitution of PNG guarantees the protection of human rights. However, in practice there have been challenges in implementing and upholding the Constitution. Several gender-related policies and strategies have been developed over the years, but have still failed to produce intended results. Implementation of these policies has been a major challenge for the public service.

PNG experiences high maternal and infant mortality rates; high crime rate; low literacy levels often caused by high gender inequalities in access to education and employment opportunities; high levels of violence against women; and low levels of women in parliament and decision-making roles. The recent 2017 election saw no women elected to the national parliament even though a number of female candidates contested the elections. In history, only seven women have been elected to national parliament since 
independence in 1975. The longest serving was Dame Carol Kidu who was in office from 1997 to 2012, for a period of three terms in parliament (Baker, 2014).

The Gender Equality and Social Inclusion (GESI) Policy (2013-15) details the challenges faced by women in PNG. Women generally have lower social status than men. This was reflected in PNG's Gender Inequality Index (GII) as 07.84 in 2008, ranking it 133 among 169 countries. Life expectancy for females is lower than males. This is partly attributed to women suffering from excessive workloads and malnutrition, high maternal mortality, and gender-based violence both at home and at work. Education enrolment rates for girls are lower than for boys, and the rates are the lowest in the Pacific region (Department of Personnel Management, 2013).

\subsection{Development Successes}

Despite the development challenges PNG faces, it continues to strive for success. PNG is now categorised as a 'lower middle income' country moving it from 'low income'. Given its demographic and economic size within the Pacific region, PNG is emerging as a regional power and contributes to regional assistance to other Pacific countries. "PNG's regional assistance to recipient countries is devised within the context of the Melanesian Way - helping brothers and sisters in need" (Development Cooperation Policy, 2015, p.20). PNG also plays a greater leadership role in the Pacific Island Forum (PIF) and Melanesian Spearhead Group (MSG). In July 2015, PNG successfully hosted the $15^{\text {th }}$ Pacific Games with participation from 22 countries in the region. At the international level, PNG has hosted the 2016 Fédération Internationale de Football Association (FIFA) Under-20 Women's World Cup tournament and was one of the three host venues of the 2017 Rugby League World Cup. In 2018, PNG will host the Asia-Pacific Economic Cooperation (APEC) forum.

\subsubsection{Development Planning}

To address development challenges, the PNG government has developed key priority development plans such as Vision 2050, Development Strategic Plan (DSP) 2010-2030 and Medium Term Development Plans (MTDP). These plans act as road maps and give guidance for long term results. Vision 2050 was developed in 2007. It is a development framework for the country's long-term strategy and reflects the inspiration of the citizens of PNG. Vision 2050's overall vision is to be a: smart, wise, fair, healthy and happy 
society by 2050 which is underpinned by seven strategic focus areas which are referred to as the pillars. These pillars are: human capital development, gender, youth and people's empowerment; wealth creation; institutional development and service delivery; security and international relations; environmental sustainability and climate change; spiritual, cultural and community development; and strategic planning, integration and control (Department of National Planning and Monitoring, 2007). The DSP is derived from the Vision 2050 and has a specific direction for economic policies, public policies and sector investments. It is envisaged that PNG will have two DSPs under the Vision 2050, each covering a 20-year period (Department of National Planning and Monitoring, 2010). The four five-year MTDPs are envisaged to be aligned to the DSP. This indicates that the MTDP's action plans, objectives, resources around programming and implementation are in line with the strategic direction of the DSP. Similarly, national and subnational governments' agency plans, corporate plans, and annual budgets must align to the MTDPs (Department of National Planning and Monitoring, 2010). All these key planning documents (Vison 2050, DSP and MTDP) include gender but each document gives it a different level of prominence. For example: Vison 2050 includes gender but combines it in the same pillar (pillar one) as Human Development, Gender, Youth and People's Empowerment. With DSP and MTDP, gender is given more prominence but takes a crosscutting approach. DSP talks about improving the Gender Development Index (GDI) through education as well as developing strategic innovative programmes that help women and girls and promote and raise awareness of the roles of men and women. MTDP emphasise the need for more gender mainstreaming and gender budgeting or genderrelated initiatives to reach communities in the lower levels of government.

\subsection{The Context of Women's Empowerment}

Gender equality and women's empowerment is an area that only recently has gained acceptance in PNG through the support of donors, NGOs, civil societies and churches. The raising of gender issues has been a rather slow and reluctant process in PNG, but there has been a push from the outside with support from donor agencies (DicksonWaiko, 2003). Even though the Constitution, several national development plans (Vision 2050, DSP 2010-30, MTDP 2011-15) and gender specific policies have endeavoured to be 'inclusive' of gender equality and women's empowerment; most have fallen short in practice and implementation due to budgetary constraints and other impeding factors. The 
trickle-down effect of these plans and strategies to all citizens remains questionable to date.

Several gender assessments and analyses have been carried out in PNG by donors and the government to understand the gender context and to identify workable strategies to address gender inequalities in the country. In 1998, the World Bank (WB) undertook a major review of its own international policy and approach to gender and as a result undertook a gender analysis in PNG in the same year. The WB found that gender issues in PNG were influenced by complex set of interrelated factors such as cultural norms and limited access to basic services such education and health. Information gaps were found to exist in statistical data to reflect the reality of the issues that women face at different levels of society; more research was needed in the role of men in gender relations; and there was a lack of information available on the roles of women in industries such as private sector and forestry (Brouwer et al., 1998).

Another gender assessment was conducted between 2011 and 2012. It was called the PNG Country Gender Assessment (CGA) and was conducted through a collaborative effort of the PNG government and its agencies, civil society, academia, community entities, private sector and bilateral and multilateral development institutions. The assessment found that GBV was widely accepted as normal and even culturally it is often condoned. Violence against women impacted on the health of women and children. It was also found that gender relations and gender inequality were significant drivers of the HIV and AIDS epidemic in PNG. PNG ranked at the bottom against world rankings in terms of women's participation in parliament and decision-making roles. The assessment also found that the Constitution provided for gender equity and equality, but customary laws recognised by the Constitution tend to discriminate against women in relation to rights and property. Finally, mainstreaming of gender across government has resulted in some sound policies and strategies, but few of these are budgeted for and implemented (Department of Community Development, 2011).

\subsubsection{PNG Government Support to Women's Empowerment}

In 1975, PNG gained independence and the Preamble to the Constitution indicated that all citizens have an equal opportunity to participate in and benefit from the development 
of the country (Anderson, 2015). The government's commitments were further affirmed through international commitments such as the Convention on the Elimination of All Forms of Discrimination Against Women (CEDAW), MDGs, Beijing-Platform For Action (PFA), Commonwealth Plan for Action for Gender and Equality, and more recently the SDGs.

\subsubsection{Gender Policies}

At the national level, the government is committed to supporting gender equality and women's empowerment through a number of gender-related policies. The National Policy for Women and Gender 2011-15 is the second policy that was developed for women and gender. The first gender policy was developed in 1991. The National Policy for Women and Gender 2011-15 is a positive policy direction for the government in its efforts in advancing gender in PNG. This policy aims to address the international gender-related commitments made by PNG as mentioned above. The policy is based on a GAD approach and takes a cross-cutting approach that aligns with other government policies. Its objective is to create an enabling policy environment that translates government's commitment to gender equality into action through the establishment of policies, programmes, structures and mechanisms. It also seeks to empower women and transform gender relations in all aspects of work, at all government levels, and in the wider community. The implementation strategy emphasises working in partnership with key partners: Office of the Development of Women; National Council of Women; national government departments; provincial governments; civil society organisations; and development partners (Department of Community Development, 2011).

Given the rise in GBV in the country, the government, together with support from the United Nations (UN) and DFAT, have recently contributed to the development of another gender-related strategy called the PNG National Strategy to Prevent and Respond to Gender Based Violence 2016-2025. The rationale for this policy is to strengthen and institutionalise the work of addressing GBV and to achieve zero tolerance towards GBV in PNG. GBV remains a social and development challenge in PNG and bears negatively on the overall development of the country. GBV has now been prioritized in the development agenda through this policy. The policy uses existing structures and processes at national and subnational level to implement this policy (Department of Community Development, 2016). This policy, along with the National Policy for Women and Gender 2011-15, are managed by the Department of Community Development.

Camilla Ethel Angoro - Master's Thesis - Victoria University of Wellington 
The National Gender Equality and Social Inclusion (GESI) policy 2013-15 is managed by the Department of Personnel Management (DPM). It was designed to assist all public servants at national and subnational level to embrace the gender equality and social inclusion principles of respect, equity and diversity. It sets a framework of gender equality and social inclusion practices for the work place and is consistent with the National Policy for Gender Equality and Women 2011-15. The policy has a twofold implementation approach: the first approach focuses on 'internal' GESI values and principles in the workplace within all public service organisations; and the second approach is 'external' in nature. The policy further embraces GESI values and principles in the design and delivery of all government-run services to all citizens. The purpose of this policy was to set guidelines for all public service in the introduction of GESI principles into policy and practice as part of service delivery outcomes for the national public service (Department of Personnel Management, 2013).

However, while there are several gender-related policies being developed to date, there are still issues around implementation of these policies especially at subnational level. This could be attributed to budgetary constraints and the lack of technical expertise at provincial and district levels.

\subsubsection{Donor Support}

There has been a huge push from the international aid agencies in PNG to support the work of gender equality and women's empowerment. Such agencies include Australia's Department of Foreign Affairs and Trade (DFAT), United Nations (UN), World Bank (WB), Asian Development Bank, Japan International Cooperation Agency (JICA), European Union (EU) and USAid, to name a few. However, for the purpose of this thesis, I will focus on one agency: Australia's DFAT.

Australia is the biggest bilateral donor in PNG and has a strong foreign and diplomatic relationship with PNG. As highlighted in Australia's Aid Investment Plan for PNG 201516 to 2017-18, “Australia values its longstanding ties with PNG - we have shared history and shared geography. As our nearest neighbour and close regional partner, a stable and prosperous PNG is clearly Australia's interest" (DFAT, 2015, p.1). Australia's relationship with PNG is "evolving, reflecting a more mature, focused and innovative response to PNG's economic development" (DFAT, 2015, p. 1). Some of the contributions noted in the 2016-17 Aid Programme Performance report for PNG 
included: working in partnership with PNG to support PNG's public service; training 14,990 public servants, including police, teachers and health workers; and providing access to better markets and essential services by completing the reconstruction of six major bridges in Oro province (DFAT, 2016, p. 2).

DFAT's sectoral programmes in PNG include health, education, improved law and justice services, transport, governance and others (including gender, humanitarian, private sector, incentive fund (is a programme that provides high-performing organisations with grants to improve service delivery and/or provide economic opportunities for the people of PNG), and support to the Autonomous Region of Bougainville). Gender and women's empowerment components are expected to be implemented within all sectoral programmes in PNG despite the nature of the programme as per the emphasis of the DFAT Gender Equality and Women's Empowerment Strategy 2016 (DFAT, 2015). DFAT is committed to supporting gender and women's empowerment in PNG. This has been evident through its development programmes (sectoral programmes) and through DFAT complementing PNG government's efforts in this domain. The aid partnership commits both governments to work together to promote gender equality and women's empowerment and increase the efforts to address family and sexual violence in PNG (DFAT, 2015). According to DFAT's Programme Performance Report for PNG 201516, 85 per cent of Australian investments effectively addressed gender at implementation in 2015-2016, exceeding the 80 per cent target in the report called 'Making performance count: Enhancing the accountability and effectiveness of Australian aid'. However, this showed a reduction of ten per cent from 2014-15, reflecting a decline in data collection and reporting on targets and the need to strengthen coordination, learning and advocacy (DFAT, 2015).

DFAT's Gender Equality and Women's Empowerment Strategy 2016 is applicable across all work undertaken by DFAT in the world. It aims to strengthen gender equality and women's empowerment as a priority across Australia's foreign policy, economic diplomacy and development efforts. This strategy "acknowledges the systems and structures that can play a significant role in entrenching or exacerbating discriminatory practices. Effective implementation of this strategy will advance the material interests of communities and economies across the Indo-Pacific region and beyond, contributing to economic growth, poverty reduction, human development and security" (Varghese, 2016, as cited in DFAT, 2016). This strategy has three priority areas: enhancing women's voice 
in decision-making, leadership, and peace building; promoting women's economic empowerment; and ending violence against women and girls and increasing access to services. Given that this is an 'international' document, it is still unclear how this strategy will be translated into the PNG context and how it can be realistically implemented incountry. It is anticipated that through my research, I may shed some light and understanding on how this strategy trickles down to subnational levels in PNG, especially in Oro province.

DFAT has supported several gender programmes and initiatives in PNG as reported in their Program Performance Report for PNG 2015-16. Australian aid assisted the implementation of the GESI Policy and the development of the PNG National Strategy to Prevent and Respond to Gender Based Violence 2016-2025; supported the Bougainville women's leadership program to assist women to develop skills and knowledge to actively participate in planning and development of community projects; invested in women's economic empowerment through the coffee industry to improve the capacity of female farmers; supported the PNG law and justice sector in its efforts to address family and sexual violence; and designed a leadership programme for PNG under Australian aid's Pacific Women programme.

\subsection{Women's Coalitions in PNG}

Women's groups in PNG whether they be affiliated with church, government, NGO, community or village, have been avenues for women to unite, share, learn and help each other grow. Two main women's organisations stand out: The National Council of Women (NCW) and various church-run women's fellowship groups.

\subsubsection{National Council of Women}

The National Council of Women (NCW) was incorporated by an Act of Parliament in 1979 which had a recent amendment in 2013. This is a state directed organisation to help women's development in the country. NCW comes under the Department of Community Development and has branches in all provinces (Department of Community Development, 2011). NCW development is shaped by direct input of rural-based women through local churches and communities. NCW has been officially recognised as the voice of women in PNG, with its membership being made up of women from all provinces around PNG. However, this organisation still faces challenges to maintain itself 
due to funding constraints (Dickson-Waiko, 2003). Many of its provincial branches do not have offices and operate out of 'temporary' venues such as under trees or use provincial or district administration facilities, wherever possible.

\subsubsection{Church-Run Fellowship Groups}

The church-run women's fellowship group is another women's organisation that contributes immensely to the empowerment of women at the local level. The Christian churches in PNG have been viewed as the "catalyst for change for grassroots women's activism in the community" (Dickson-Waiko, 2003, p. 103). Historically, churches have been supportive of the wider PNG community. In the early 1950s, churches provided an avenue for women to organise themselves through the leadership of the wives of pastors, ministers and priests. Churches also provided basic services such as health and education in remote areas, where there were limited government services. These enabled girls to access education and be empowered. While religious organisations are often ignored within international development debates (Clarke, 2015), churches in PNG do provide an innovative delivery mechanism through which some aid flows can be directed. Recently, churches have been engaged to assist in the delivery of some development programmes in PNG in the area of gender and women's empowerment. Anderson (2015) emphasises the importance of development policy and practice engaging with religious organisations in addressing gender concerns. She focuses on the PNG Church Partnership Programme (CPP); a DFAT-funded intervention where religion and development intersect. CPP and the seven main Christian churches have provided an avenue for women to feel empowered; in the sense that women feel active and are participatory members of the community. Some of these female leaders have held positions in church and feel they have the ability to stand up and be a voice in decision-making (Anderson, 2015).

\subsubsection{Examples of Community-Led Women's Groups}

Other community-led women's groups who have had positive impacts on women at the subnational level are: Bougainville Women's Federation (BWF) from the Autonomous Region of Bougainville (ARB) and Kuk Women for Peace (KWP) from Simbu province. Both organisations have been working in their communities to bring peace. KWP is comprised of female activists in the Kup sub-district of Simbu province who strive to address tribal fights and violence against women (including sorcery-related killings) and 
children. This group works closely with local police, churches and village courts (Garap, 2004). BWF was formed in 2008 following the Hutgena Accord of 2006 that all women in Bougainville unite in the implementation of the Bougainville Peace Agreement (Hako Women's Collective, 2017). BWF works in partnership with PNG NCW and other international organisations such as DFAT and UN agencies. One of their milestones was successfully constructing their own office with funding through the Australian aid programme. This building was officially opened by Natasha Stott Despoja, Australia's Ambassador for Women and Girls, on the $10^{\text {th }}$ of February 2016. This office will give women a proper place to work and discuss issues of concern (Australian High Commission, 2016).

\subsection{Oro Provincial Profile}

Figure 2: Map of Oro (Northern) Province (including Sohe and Ijivitari Districts).

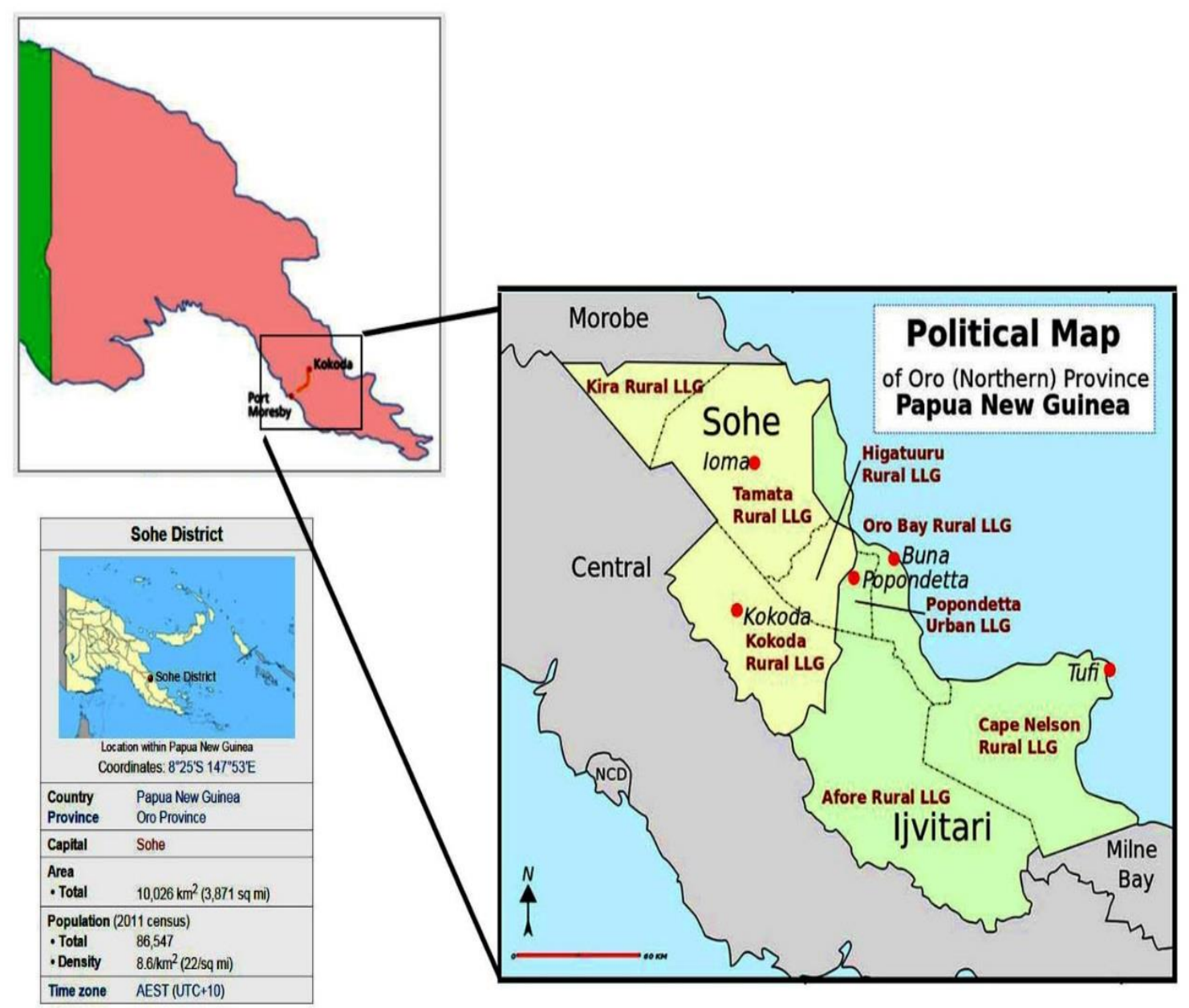

Source: Sohe District in the Spotlight 


\subsubsection{Demographics}

Oro province (formerly known as Northern province) is one of the twenty-two (22) provinces of PNG. Popondetta is the township and provincial headquarters where most of the government services and businesses are located. It has a population of 186,309 according to the 2011 national census (National Statistics Office, 2011). Oro has two districts of Sohe and Ijivitari and shares provincial boarders with Morobe, Central and Milne Bay provinces. The main Christian denomination is the Anglican Church.

\subsubsection{Economy and Development Challenges}

The Oil palm crop is the primary industry of the province generating income for many families. The north end of the Kokoda trail runs into the province and this historical track is one of the main tourist attractions in the province and indeed the country as a whole. This track carries significant historical connections for Australia given the World War Two (2) battle was fought on this track in 1942. The province is based on a subsistence economy as most communities live in rural areas and engage in subsistence farming and fishing. Forestry and other cash crops such as cocoa, copra, rubber, and coffee generate income from the province (Sohe District Administration, 2012). Oro province still faces development challenges like any least developing province in PNG. Basic services such as health and education are still lacking. Infrastructure is in a poor state, especially after Cyclone Guba devastated the province in 2007. Deteriorating roads and airstrips and the lack of sea transportation make it impossible to move goods and services closer to the rural communities (Sohe District Administration, 2012).

\subsubsection{Donor Support}

Oro province has been receiving donor support over the years; the main donor being the Australian government through DFAT. Oro province has historical connections with Australia through the Kokoda Trail. A number of DFAT programmes have been implemented in the province to date. It must be noted that the programmes discussed here are ones that have information available to the public. There may be other programmes that support the province, but on a smaller scale or through collaboration between the PNG Government and other donors other than DFAT. The current DFAT programmes being implemented in Oro province are: PNG Governance Facility (PGF), Kokoda Initiative (KI) programme; Justice Services and Stability for Development (JSS4D); 
Transport Sector Support Programme (TSSP); Health and HIV Implementation Services Provider (HHISP); Education Programme; and Australian Awards which offers domestic and international scholarships to PNG citizens, including citizens of Oro. I will only give details of programmes that I have information on and are known to the research participants in this research.

PGF, since June 2016, manages all governance-related programmes. In Oro province, PGF continues the work of the former Provincial and Local-Level Government Programme (PLGP), the Church Partnership Programme (CPP), and the former Strongim Pipol Strongim Nesen (SPSN) Programme. PGF's focus is at district level and it works in Sohe District (one of two districts in Oro province) as well as providing continuous support to Oro Provincial Administration (OPA). KI Programme comes under PGF but operates as an individual programme. It supports Kokoda Track communities through community development initiatives. It is a partnership programme between the Australia and PNG governments to sustainably develop and protect Kokoda Track and its surrounding areas. KI supports livelihood improvements for landowners and communities through health, education and sanitation projects, and through income generation activities (DFAT, 2015). TSSP assisted with rehabilitation of six bridges (four larger bridges and two smaller bridges) between 2014 and 2016. The JSS4D programme contributes to community safety, addressing family and sexual violence, law and justice and anti-corruption. It also supports women's empowerment through its gender component in Oro province (DFAT, 2016).

\subsubsection{Women's Empowerment in Oro Province}

Women's empowerment in the province has been supported by the government, churches and development partners, mostly DFAT. It must be noted that there are no DFAT 'gender' specific programmes being implemented in Oro province, but generalist programmes. However, these programmes have elements of gender and are expected to incorporate 'gender' aspects in all programme activities (at least 80 percent) as per the DFAT Gender Equality and Women's Empowerment Strategy 2016.

PNG NCW (provincial branch) is one of the main women's organisations in the province but it has been ineffective over the years due to funding constraints and the lack of resources to carry out their mandated responsibilities. Government support through the Division of Community Development under OPA is mandated to provide support to 
women but is limited in resources and funding (Department of Community Development, 2011).

The Anglican Church has played a major role in supporting women's empowerment through the church-run fellowship groups and through their development programme called Anglicare Stop Aids, which is jointly funded by DFAT's CPP programme and the Anglican church of Australia.

\subsection{Summary}

PNG still faces development challenges particularly given its large size, unique geography, and its scattered and diverse population. PNG achieved has some success over the years, but more needs to be done even after 42 years of being independent. Gender inequalities between men and women and a rise in violence against women have impacted on some development outcomes. With the joint effort from donors, the PNG government and women's groups, gender inequality has been given prominence and efforts have begun to address the issue more systematically through the various mechanisms in place. This is a positive direction for the development of PNG, but much more needs to be done, including a need to focus on outcomes at sub-national level. 


\section{Chapter Four: Methodology}

\subsection{Introduction}

In this chapter, I discuss my research methodology including epistemology, conceptual framework, and research methods used. Overall, my research is a qualitative study to understand how Australia's Gender Equality and Women's Empowerment Strategy contributes to the empowerment of women in Oro province, PNG.

\subsection{Constructivism}

Epistemology is the study of knowledge and how knowledge of the world is learnt. It is important to consider one's own epistemological position, as one's world view and epistemology can inevitably influence the way research is undertaken (Bryman, 2016, as cited in Kara, 2017). For the epistemology for my research, I used constructivism to understand the different participants in my research and how they construct their realities which are being investigated through this research. Constructivists believe that there is no independent reality for us to observe and measure, but multiple realities (Robson \& McCartan, 2016, as cited in Kara, 2017). This research involves gathering and analysing participants' perspectives around aid and women's empowerment through a combined effort of both the participants and myself (the researcher). Even though constructivism is sometimes criticised for being too specific and lacking rigour, it has been proved to be useful in other research on the views of diverse groups of people. For example, the use of constructivist learning of pupils in schools (Adams, 2006): "the fluid nature of constructivist learning requires the reader to adapt the view that each pupil will construct knowledge differently and that these differences stem from the various ways individuals acquire, select, interpret and organise information" (p. 245). Similarly, my research looks at the different views of participants in order to create meaning around women's empowerment and the support from DFAT in Oro province, PNG.

\subsection{Grounded Theory}

The strategy of inquiry for my study is informed by grounded theory. Grounded theory according to Creswell (2009) is when a researcher derives a general abstract theory of a process, action or interaction from in the views of the participants. It can have multiple stages of data collection and refinement. I chose grounded theory as my methodology because it is a theory that is derived from or 'grounded' in the everyday lived experiences 
of people. The foundations of grounded theory are embedded in symbolic interaction, which assumes that one's communications and actions express meaning (Byrne, 2001). Participants in my research expressed themselves through interviews and a focus group discussion which contributed to understanding the context of the issue being investigated through this research. Their 'lived experiences' were able to contribute towards the shaping of my findings and results in this research (see Chapter 5: Key Results for details on the interview and focus group discussion).

\subsection{Theoretical Frameworks}

Given the nature of my research question, my research is informed by post-structural feminist theory, the GAD approach, and women's empowerment framework. The rationale for using three theoretical frameworks was to understand the different perspectives embedded within my research topic.

\subsubsection{Post-Structural Feminist Theory}

Post-structural feminism is a theory that pays attention to the issue of knowledge, power, difference and discourse and how they intersect and entwine in the lives of women. The combination of feminism and post-structuralism brings about a strong resistance of modernity; offering critiques and examines taken-for-granted notions of the subjectivity and identity of women (English, 2012). Post-structural feminist theory sees women as not one unified, coherent group with a singular identify but with many identities as they constantly create their own meanings, thus freeing themselves from labels, cultural expectations and norms (English, 2012). It was important that I recognised women as active participants in my research. I also recognise that participants construct their own meanings of their realities based on their lived experiences.

Within post-structural feminist theory, the notions of knowledge, power, difference and discourse are pre-eminent. A poststructuralist view on discourse is that the voice and words of participants could not ensure validity and truth. The meaning of a word changes depending on the context it is being used in or the person it is being addressed to (St.Pierre, 2008, as cited in Varga-Dobai, 2012). What a question or answer means to a researcher can easily mean something else to an interviewee. "Language is a place where identities are built, maintained or challenged; it is a place for transformation" (VargaDobai, 2012, p.6). It was therefore important in my research to understand the context in

Camilla Ethel Angoro - Master's Thesis - Victoria University of Wellington 
which all my participants were coming from in order to be able to understand their realities. Post-structuralism sees power as being fluid and held by everyone. It is less interested in institutional power dynamics but more focused on the everyday use of power by individuals as opposed to being owned and used by dominant elites (English, 2012). In my research, notions of power were present. Each participant group held different levels of power during interviews. For example: DFAT officials seemed to hold more power because they were representing the donor and Australian Government compared to the newly established Ward 10 Council of Women's Organisation in Oro province. Also, as the researcher, I recognised I held a certain level of power that I carried with me throughout the research process (refer to section 4.5.4 on positionality on field work for more details).

\subsubsection{The GAD Approach}

I chose the GAD approach because I wished to understand how local women in my research are involved in the developmental process through the implementation of key DFAT and PNG government strategic policy documents on gender and women's empowerment. The GAD approach brings together both gender relations and the development process. It also seeks to enhance women's empowerment through the politicisation of practical gender needs (such as the need to provide food, shelter, education, and health care) and their transformation into strategic interests (Connelly, Li, MacDonald \& Parpart, 2000). GAD also recognises the different impacts of development policies and practices on women and men and sees women as agents, not simply as recipients of development. The GAD approach maintains that the "focus on women in isolation is to ignore the real problem, which remains their subordinate status to men. In insisting that women cannot be viewed in isolation, it emphasises a focus on gender relations, when designing measures to 'help' women in the development process" (Moser, 1993, p.3). Connelly et al. (2000) write that women's status in society is deeply affected by their material conditions, status in society and position in the national, regional and global economies. They write that GAD recognises that women are deeply affected by the nature of patriarchal power in their societies at national, community and household levels. The GAD approach focuses on the intersectionality of gender, class, race, and social constructions of women. This point was earlier emphasised by Moser (1993) with regards to women in the Third World, noting that women experience oppression differently, accordingly to their race, class, colonial history, culture, and position in 
international economies. Having highlighted aspects of the GAD approach, it is important that women in my research are seen as 'agents' of change and not just 'recipients' of development.

\subsubsection{Women's Empowerment Framework}

I chose to use women's empowerment as a theoretical framework informing my research because overall, my research focuses on 'empowerment' of local women in Oro province. I was primarily interested in the different notions of the 'empowerment of women' that were particularly appropriate for a developing country in the Pacific region. As earlier discussed in my literature review chapter, there are different notions of empowerment and meaning differs between individuals and groups, depending on their contexts and status in society. Overall, empowerment is having 'power' in terms of the ability to make choices. Empowerment entails change and it can be explored through three closely interrelated dimensions of agency, resources and achievement (Kabeer, 2005): "agency represents processes by which choices are made and put into effect. It is hence central to the concept of empowerment. Resources are the medium through which agency is exercised; and achievement refers to the outcomes of agency" (p. 14). According to Mosedale (2005), different people use empowerment to mean different things. She points out four aspects of women's empowerment: firstly, to be empowered, one must be disempowered; secondly, empowerment cannot be bestowed by a third party, rather those who would become empowered must claim it; thirdly, definitions of empowerment usually include a sense of people making decisions on matters which are important in their lives and being able to carry them out; and finally, empowerment is an ongoing process rather than a product. There is no final goal of empowerment. According to several studies done on empowerment, their definitions suggest that 'empowerment' entails elements of power, autonomy and self-reliance, entitlement, participation, and the process of building awareness and capacity embedded within it. However, the most important was the notion of power (Panda, 2000). Power as in having 'power over'. Foucault (1982, as cited in Panda, 2000) uses a different mode of power, which is not infinite. Power is relational and something which exists only in its exercise. Power is constituted in a network of social relationships among subjects who are free to at least a minimal extent; without power those relationships cannot exist. 


\subsubsection{Summary of Attributes of All Theoretical Frameworks}

Table 1: Summary of Attributes for All Three Theoretical Frameworks

\begin{tabular}{|c|c|c|}
\hline $\begin{array}{l}\text { Post-structural feminist } \\
\text { theory }\end{array}$ & GAD & $\begin{array}{l}\text { Women's empowerment } \\
\text { framework }\end{array}$ \\
\hline $\begin{array}{l}\text { - Women not one } \\
\text { unified group but } \\
\text { having many identities } \\
\text { and creating their own } \\
\text { meaning } \\
\text { - } \text { Knowledge } \\
\text { - } \text { Power } \\
\text { - } \text { Difference } \\
\text { - } \text { Discourse }\end{array}$ & $\begin{array}{l}\text { - } \text { Gender relations } \\
\text { - } \quad \text { Recolopment } \\
\text { different impacts of } \\
\text { development policies } \\
\text { on women and men } \\
\text { - Sees women as agents } \\
\text { and not simply as } \\
\text { recipients of } \\
\text { development } \\
\text { Women should not be } \\
\text { viewed in isolation } \\
\text { Women are affected by } \\
\text { the nature of } \\
\text { patriarchal power } \\
\text { Focuses on the } \\
\text { intersectionality of } \\
\text { gender, class, race and } \\
\text { social constructions of } \\
\text { women }\end{array}$ & $\begin{array}{l}\text { - } \text { Power } \\
\text { - Agency } \\
\text { - Resources } \\
\text { - Achievement } \\
\text { - An ongoing process } \\
\text { - } \text { not a product } \\
\text { - Autonomy } \\
\text { - } \text { Self-reliance } \\
\text { - } \text { Partitlement } \\
\text { - Process of building } \\
\text { - } \text { awareness } \\
\text { Capacity building }\end{array}$ \\
\hline
\end{tabular}

Having reviewed the three aspects of my theoretical framework (post-structural feminist theory, GAD and women's empowerment), the notion of power appears to be present in all three theoretical frameworks. The notion of power occurs at different levels within these frameworks. A feminist model of power draws on Foucault's (1982) mode of power but incorporates a gender analysis of power relations and the understanding of internalised oppression that creates barriers to women's exercise of power contributing to inequality between women and men (Rowlands, 1998). Reflecting on the feminist model of power, post-structural feminist theory understands power as "discursively constructed, spatially and materially located" (Davies \& Gannon, 2011, p. 313). Power is understood in terms of the lines of force. It is not the property of one gender. Its strategies, its manoeuvres, its tactics and techniques are always contingent and unstable (Deuze, 1998, as cited in Davies \& Gannon, 2011, p. 314). GAD defines power through the different definitions of empowerment. To be empowered is to be invested in power (Peake, 1999, 
as cited in Sharp, Briggs, Yacoub \& Hamed, 2003). Similarly, to GAD, the women's empowerment framework encompasses the notion of power that women possess and their ability to use this power to better their lives. Batliwala (1994) states that empowerment should result in understanding that both men and women are equal beings regardless of gender.

The diagram below shows the interconnectedness of the frameworks through the notion of power. Notably the notion of power is present in all three theoretical frameworks.

Figure 3: Diagram Showing the Interconnectedness of Theoretical Frameworks

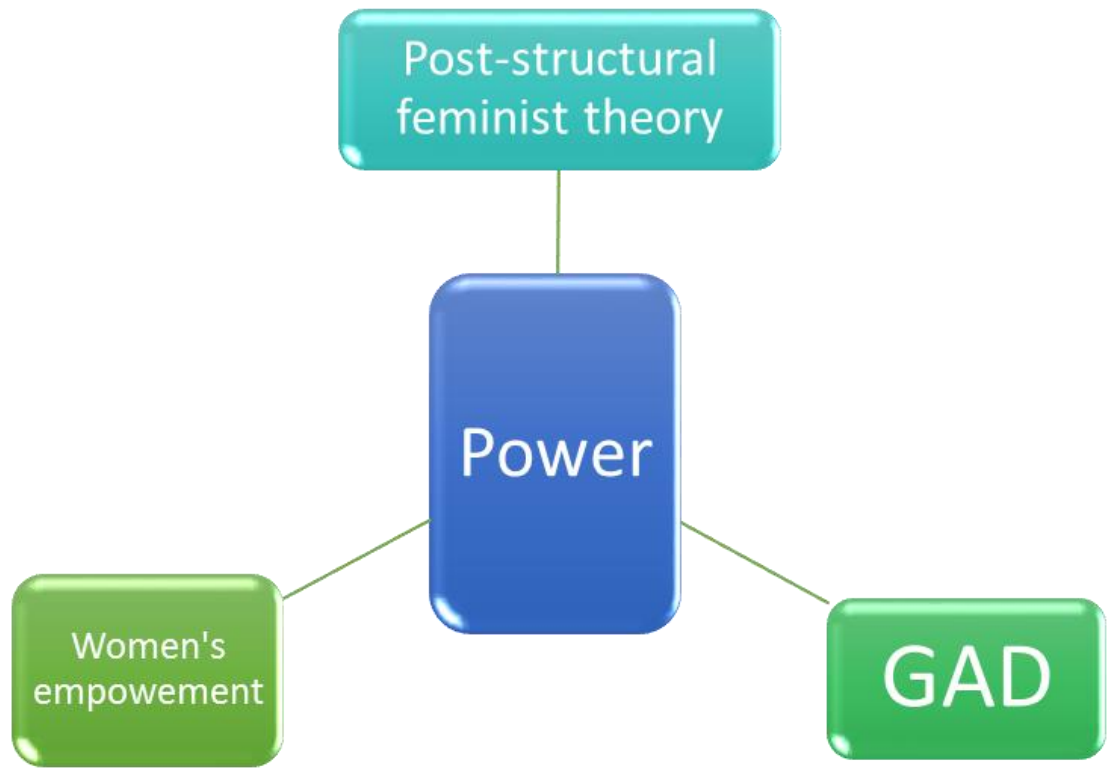

\subsection{Research Methods}

\subsubsection{Participant Selection}

My fieldwork ran from the $22^{\text {nd }}$ of May 2017 to the $19^{\text {th }}$ August 2017 in Port Moresby (NCD) and Popondetta (Oro province) of PNG. Participants were selected from three of the four target groups identified earlier in my research proposal. The target groups were DFAT officials, government officials (national and subnational), politicians (local members of parliament), and local women's groups. Unfortunately, one group (politicians) had to be dropped from the interviews as timing would not allow them to participate in my research due to the PNG 2017 national elections being conducted within the same time frame as my field work. Even though Victoria University of Wellington (VUW) Research Ethics Approval was obtained for the four groups of participants, only 
three groups were interviewed: DFAT officials, PNG government officials, and a local women's group.

With DFAT officials, I initially used my network as I had worked previously with one of DFAT's programmes. However, this connection could not enable me to speak to the head of the gender team at the Australian High Commission in Port Moresby. This resulted in four weeks of waiting before I asked my interim supervisor at VUW and NZAID Scholarship Manager at VUW to ask New Zealand High Commission in Port Moresby to assist with an appointment and possibly an interview. This assistance worked out and I was able to speak to the gender team who then helped me with contacts of other DFAT programmes that support Oro province. I also used my own network to select participants at programme level. With PNG government officials, I used my network initially then used the snowball technique to select other participants identified by my contacts. However, most 'potential' interviewees were involved with the elections or had some level of commitment to the elections so that they could not participate in the interview. I was unable to interview an official from a key government agency (Department of Community Development) as timing was not conducive. I initially had a meeting but could not confirm the interview. This was unfortunate as this organisation is the custodian of the key gender policy in PNG. With the other two government agencies, I had to follow protocol and write a formal letter to the head of agency (Secretary) to seek approval before I could interview any official. (See Appendix $3 \& 4$ ). This process took some time but I was able to get the interviews done.

At provincial level, certain key staff at OPA were also involved with the elections, so that I was not able to interview them. Being from Oro province, I used my networks as well as my family members who work in OPA. For the local women, I used my network as well as my family to assist. I choose Ward 10 (Popondetta Urban LLG, Ijivitari District) Council of Women's group as their organisation is affiliated to the NCW. In addition, there were no local women's groups that I understood were receiving 'direct assistance' from DFAT and therefore I decided to select Ward 10 Council of Women's Group. This decision was mainly due to my budget, timing of my fieldwork, and distance from my place of residence during field work. I also interviewed other women individually who did not necessarily belong to a women's group. 


\subsubsection{Interviews}

Interviews began in Port Moresby on the $8^{\text {th }}$ of June 2017 as formal approvals had to be obtained from agency heads of some participants prior to interviews being conducted. In the twelve weeks of fieldwork, nineteen (19) interviews and one focus group were conducted from a pool of twenty-four (24) scheduled interviews. Five (5) interviews were cancelled, as participants were not able to make the interview due to their busy schedules. Interviews were conducted in Port Moresby (NCD) and Popondetta, Oro province. Interviews in Popondetta were somewhat disrupted as the counting of votes for the national elections (Oro provincial and Sohe and Ijivitari electorate seats) was taking place within the premises of OPA, and there were instances where I had to go past security checks by Police officers to get to my interview venue. This was mainly for the interviews for participants from OPA. I was glad I had my VUW identification card as it helped clarify that I was a genuine student and was only there for educational purposes. In summary, nineteen (19) individual interviews, one (1) focus group discussion with six (6) women were conducted. Together there were twenty-five (25) participants; six (6) males and nineteen (19) females, representing eight organisations at national and sub-national levels (Oro province).

\subsubsection{Semi-Structured Interviews and Focus Group Discussion}

I used semi-structured interviews and a focus group for my primary data collection mode. I chose both modes as I felt it was more appropriate given the qualitative study and grounded theory methodology that I employed in the research. The decision to use a focus group discussion was primarily because all my potential interviewees from the women's group turned up at the exact same time at my family's residence in Sorovi, Ward 10 area (Popondetta, Oro province). I felt it was a good opportunity that everyone was present to give me their insights, hence the decision to conduct a focus group instead of a number of individual interviews. This group was made up of executives of the organisation and two members.

A thematic list of four topics was generated for each participant group prior to the interviews and generic questions were asked with regard to those topics. These topics were in line with my four research questions: DFAT's and PNG government's contributions to women's empowerment in Oro; collaboration to support women's empowerment initiatives; and support to local women's groups. (See appendix 15 for generic question guide for each group). Most interviews were audio recorded but a few 
declined the permission for recording, in which case I respected their wishes and turned off the audio recorder. After each interview, I completed a 'tracking sheet of interviews' which was basically an Excel sheet that identified the participant by name or alias, gender, date of interview, agency, interview identification code, and general comments which later helped me with the write up of my interview summaries. From the interview notes and the audio recordings, I was able to produce summaries of each interview. I also kept a field journal that I made notes each day; regarding my reflections on the interviews; how my day progressed; as well as other issues that needed to be actioned to progress my field work.

Table 2: Table of Interview Participants by Gender, Date and Agency.

\begin{tabular}{|c|c|c|c|c|}
\hline No. & Gender & Date & $\begin{array}{l}\text { Data collection } \\
\text { method }\end{array}$ & Agency \\
\hline 1 & $\mathrm{~F}$ & $8 / 06$ & Interview & $\begin{array}{l}\text { Department of National Planning } \\
\text { and Monitoring }\end{array}$ \\
\hline 2 & $\mathrm{M}$ & $15 / 06$ & Interview & $\begin{array}{l}\text { Department of Personnel } \\
\text { Management }\end{array}$ \\
\hline 3 & $\mathrm{~F}$ & \multirow[t]{2}{*}{$21 / 06$} & Interview & \multirow{2}{*}{$\begin{array}{l}\text { DFAT }- \text { Australian High } \\
\text { Commission, Port Moresby }\end{array}$} \\
\hline 4 & $\mathrm{~F}$ & & Interview & \\
\hline 5 & $\mathrm{~F}$ & $10 / 07$ & Interview & Anglicare PNG - Oro province \\
\hline 6 & $\mathrm{M}$ & $12 / 07$ & Interview & $\begin{array}{l}\text { International Organisation for } \\
\text { Migration - Oro province }\end{array}$ \\
\hline 7 & $\mathrm{M}$ & $12 / 07$ & Interview & $\begin{array}{l}\text { Division of Community } \\
\text { Development - OPA }\end{array}$ \\
\hline 8 & $\mathrm{M}$ & $12 / 07$ & Interview & $\begin{array}{l}\text { Human Resources Division - } \\
\text { OPA }\end{array}$ \\
\hline 9 & $\mathrm{~F}$ & $12 / 07$ & Interview & $\begin{array}{l}\text { Human Resources Division - } \\
\text { OPA }\end{array}$ \\
\hline 10 & $\mathrm{~F}$ & $17 / 07$ & Interview & $\begin{array}{l}\text { Oro Provincial Council of } \\
\text { Women }\end{array}$ \\
\hline 11 & $\mathrm{~F}$ & $17 / 07$ & Interview & $\begin{array}{l}\text { Finance and Audit Branch - } \\
\text { OPA }\end{array}$ \\
\hline 12 & $\mathrm{~F}$ & $19 / 07$ & Interview & $\begin{array}{l}\text { Department of Justice and } \\
\text { Attorney General - Oro Branch }\end{array}$ \\
\hline 13 & $\mathrm{~F}$ & $19 / 07$ & Interview & Local Woman - Kokoda LLG \\
\hline 14 & $\mathrm{~F}$ & \multirow[t]{2}{*}{$20 / 07$} & \multirow{2}{*}{$\begin{array}{ll}\text { Focus } & \text { Group } \\
\text { Discussion } & \end{array}$} & \multirow[t]{2}{*}{ Ward $10-$ Council of Women } \\
\hline 15 & $\mathrm{~F}$ & & & \\
\hline
\end{tabular}




\begin{tabular}{|l|l|l|l|l|}
\hline 16 & F & & & $\begin{array}{l}\text { Popondetta Urban LLG, Ijivitari } \\
\text { District, Oro province }\end{array}$ \\
\cline { 1 - 2 } 17 & F & & & \\
\hline 19 & F & & & \\
\hline 20 & M & $28 / 07$ & Interview & $\begin{array}{l}\text { DFAT }- \text { Justice Services and } \\
\text { Stability for Development } \\
\text { Programme }\end{array}$ \\
\hline 21 & F & $01 / 08$ & Interview & $\begin{array}{l}\text { DFAT }- \text { Kokoda Initiative } \\
\text { Programme }\end{array}$ \\
\hline 23 & F & $01 / 08$ & Interview & $\begin{array}{l}\text { DFAT }- \\
\text { Programme Pacific Women }\end{array}$ \\
\hline 24 & M & $08 / 08$ & Interview & DFAT - Education Programme \\
\hline 25 & F & $10 / 08$ & Interview & $\begin{array}{l}\text { DFAT - PNG Governance } \\
\text { Facility }\end{array}$ \\
\hline
\end{tabular}

\subsubsection{Positionality in Field Work}

Merriam, Johnson-Bailey, Lee, Kee, Ntseane \& Muhamad (2001) write that positionality is determined by where one stands in relation to the other in research. Positionality directly affects fieldwork, as fieldwork is a dialogical process structured by the researcher and the research participants (England, 1994). "Field work is intensely personal, in that positionality and biography of the researcher plays a central role in the research process, in the field and as well as in the final text" (England, 1994, p. 87). Nazneen and Sultan (2014) highlight that positionality, analysis of power relations and transformative knowledge production are issues and practices that feminist social scientists find difficulty with during fieldwork, analysis and presentation of results. For example, the feminist research carried out by Nazneen and Sultan (2014) on women's empowerment in Bangladesh identified that they had to explore their own assumptions (as researchers) on feminist practices in dealing with positionality and the analysis of power relations between the researcher and research participants. For my research, it was important to be aware of my positionality as I conducted my fieldwork, especially during interviews. I focused on two aspects of positionality while carrying out fieldwork: insider/outsider and having power. Power as a researcher, and power within research participants both individually and through the organisations organisation they represented. As a 'local' woman from Oro province, I was aware of where I came from and so I was an 'insider' 
in that sense. I fitted into the context and was aware of the local issues given my personal connection to the locality. However, I was also an 'outsider' in that I was a postgraduate student, being educated overseas, who had also left home (Oro province) to live and work in Port Moresby city for some time. That created some barriers for some local women to talk openly during the interviews. I felt they held back during the introductions of the interviews, but when I opted to use the local language (Binandere) it was welcomed by all as it helped them to openly converse through the interviews. Power was another aspect of positionality that I had to be mindful of during interviews. Power existed within the three groups of participants I interviewed and it varied throughout the individual interviews. This was more so with DFAT officials at the Australian High Commission and within national government agencies in Port Moresby. I also noted that I had elements of 'power' as the researcher. I had to navigate through the interview process how I used that power to be able to ensure that the research participants felt they were part of the process and that I was not dominating the whole process of the interviews.

\subsubsection{Document Review}

My key secondary data came from PNG government and DFAT strategies, plans, reports, as well as local newspaper articles. All documentation was reviewed to identify thematic areas within my research topic. These areas were around gender and women's empowerment and donor support. With reference to PNG government policies around gender and development, I generally looked at key policies' objectives and their implementation plans. This was to give me a sense of what each policy was designed to do, understand the nature of the context before interviewing participants which enabled me to understand the progress and situation on the ground. With DFAT documents, I looked at the DFAT Gender Equality and Women's Empowerment Strategy in detail as it is the key document that my research is centred around. I then proceeded to look at programme design documents of key programmes that support Oro province, specifically looking at the gender components within programmes. This was because there is no gender specific programme that supports Oro province. All programmes are generalist and have different objectives. I also reviewed recent DFAT Aid Programme Performance Reports for PNG. This was to understand how DFAT addresses gender and women's empowerment within the different programmes since the DFAT Gender Equality and Women's Empowerment Strategy came into effect in 2016. 


\subsubsection{Methods for Data Analysis}

I chose not to use any qualitative research analysis software (such as Nvivo and others); due to my research budget and the limited time, I had to get writing underway for the completion of this research. Instead, I decided to manually analyse my primary data (interview summaries) and secondary data (mostly key plans, strategies and reports) using content analysis. Julien (2012) writes that content analysis is the intellectual process of categorising qualitative textual data into clusters to identify patterns and relationships between variable or similar entities and create conceptual categories to identify consistent patterns and relationships between variables and themes. This analytic method is a way to reduce data by making sense of it and deriving meaning. For the data analysis process, I saved all interview summaries into one document. Then I printed this document and reviewed each line of each paragraph to see what main message was coming out from the interview summaries. I then colour coded similar themes that were emerging. This then helped me identify the key themes that my findings would be based on. Once I had the main themes in place, I had to look at my interview transcripts to find suitable quotes as evidence to justify the points which best reflected the themes.

\subsection{Research Ethics and Considerations}

\subsubsection{Ethics}

It is extremely important to be mindful of ethical considerations during qualitative research. Qualitative research often uncovers sensitive data and informed consent should always be sought and participants should have the right to withdraw their data at any time (Urquhart, 2013). Ethics is about maintaining privacy of participants' information, reporting and analysing data honestly and taking responsibility for research findings (Maylor \& Blackmon, 2005, as cited in Urquhart, 2013). Ethical considerations influence aspects of the research process and help researchers decide whether a specific field of study or specific investigation is ethically acceptable. Many ethical issues arise during the data collection phase and researchers need to respect research participants and sites (Creswell, 2009). Ethics approval for my research was granted by the Victoria University of Wellington's Ethics Committee on the $12^{\text {th }}$ of May 2017, ahead of my fieldwork. The ethics approval process involved the completion of a formal ethics application online in consultation with my supervisor. The application involved completing questions regarding fieldwork: generally, type of participants, location, how to address issues around confidentially, and storage of data during fieldwork and after. I had to provide 
samples of consent forms and information sheets for all four groups of participants. (See Appendix 4 to 9). This process took two and a half months.

An important point worth noting was potential ethical issues around confidentially with the information participants gave me. Given that my research involved a donor, a recipient government, and a women's groups; I had to deal with information from each group very carefully given the sensitivity. There were instances that participants were worried that the information they gave me could jeopardise their ability to receive future funding or some kind of assistance. I assured them that the information they gave me would only remain with me and my supervisor for three years after the study was completed. I also assured them that what I would use in my final report, was a summarized version of their interviews, and so it would not include any direct negative comment attributed to any participant group that they felt would put them in jeopardy.

\subsubsection{Reflexivity}

It is important to bear in mind reflexivity when conducting research. Reflexivity is the critical self-reflection of one's biases and theoretical predispositions throughout the research process (Schwandt, 1997, as cited in Urquhart, 2013). Reflexivity is a process that involves conscious self-reflection on the part of researchers to make explicit their potential influence on the research process. Through reflexivity, qualitative researchers reflect on their subjectivity; on how their social background, assumptions, positioning and behaviour impacts on the research processes (Finlay \& Couch, 2003, as cited in Hennink, Hutter, \& Bailey, 2011). Reflexivity has two aspects that are worth distinguishing, as both can potentially influence data generation in qualitative research. Reflexivity may be considered personal or interpersonal. Within personal reflexivity, the researcher reflects on their background and assumptions as it could influence the research and data creation. Interpersonal reflexivity recognises that the interview settings and interpersonal dynamics between researcher and participants also influences knowledge creation (Hesse-Biber \& Leavy, 2006, as cited in Hennink, Hutter, \& Bailey, 2011). It was therefore important to be mindful of the concept of reflexivity as I conducted my field work and throughout the whole research process. For example, before I started my research, I chose a topic and location that reflected elements of my background. As a woman from Oro province and PNG, this study would contribute to understanding some of the issues faced by PNG women and the support they receive to address these issues. In addition, I had previously worked with DFAT and understood the nature of support 
given to Oro province, and therefore wanted to understand how much of that support did eventually trickle down to rural women in the province.

\subsection{Summary}

A qualitative study informed by constructivism and grounded theory enabled my research to be open and flexible to participants' views and to understand that both the participants and I (the researcher) contributed to creating knowledge. Using three different approaches (post-structural feminist theory, GAD and women's empowerment framework) to inform my theoretical framework gave me a wider perspective on the issues I was investigating. Being mindful of my positionality and reflexivity as a researcher was of paramount importance. It helped me navigate through the issues of power and knowledge creation, and how to approach different participants and situations that arose during my fieldwork. 


\section{Chapter Five: Key Results Showing DFAT and PNG Government's Support to Women's Empowerment in PNG}

\subsection{Introduction}

This chapter uses interview and policy document review summaries to discuss the key themes that emerged from the findings: implementation and ownership of policies, collaboration to leverage positive outcomes, and notions of empowerment. These themes emerged as a result of understanding the nature of support from DFAT and the PNG government towards supporting women's empowerment initiatives in Oro province; and also as a result of understanding policy implementation and its contribution to achieving the intended outcomes/results for its beneficiaries.

\subsection{Implementation of Policies}

Findings from the interviews indicated issues around implementation of policies and strategies with regards to DFAT's Gender Equality and Women's Empowerment Strategy 2016 in PNG; and with regards to PNG's development and gender policies: Development Cooperation Policy 2015, National Policy for Women and Gender 2011-15 and Gender Equality and Social Inclusion (GESI) Policy 2013-15.

\subsubsection{Aid Coordination in PNG}

The foreign aid division of the Department of National Planning and Monitoring (DNPM) is responsible for the overall aid coordination, monitoring and reporting of ODA to PNG. The Development Cooperation Policy launched in 2015 outlines the protocols and guidelines for engagement with development partners. The policy's key objectives are: to identify development cooperation sources and devise appropriate strategies; strengthen partnerships between key institutions and stakeholders involved in development mobilization, coordination, performance management and delivery, focusing on development capacity strengthening systems; and institutionalize and coordinate PNG's regional assistance to recipient countries devised within the context of the Melanesian Way - "helping brothers and sisters in need" (Department of National Planning and 
Monitoring, 2015, p.20). The implementation of this policy guides the department and donor agencies in a way that is coordinated and beneficial for all parties.

Foreign aid division screens all proposals for grant funding and loan financing. Appraisals are done and Department of Treasury is informed. Treasury is the only state agency that commits to any loan obligation on behalf of the government. In recent years, many of the processes were not followed. Ministers and agencies go direct to banks. But with the development cooperation policy, it sets out clear directions on aid coordination. The department's challenge now is to implement this strategy to ensure that everyone complies to the process to have a coordinated approach in engaging with development partners. PNG at the Pacific regional level is a donor too. (Interview, Government Official, June 2017)

This indicates that the Development Cooperation Policy helps provide guidance to ensure aid is coordinated well in PNG. However, the implementation of this policy has to be done well in order for government officials and members of parliament to abide by. In theory, this policy should also help bolster a co-ordinated approached to gender and women's empowerment, or at least have elements of it. The Development Cooperation Policy does not explicitly include gender but states it is aligned to Medium Term Development Plan (MTDP) 2 (2016-2017). MTDP 2 envisages to address gender through the plan's alignment with the Government's Five National Goals and Directive Principles of the Constitution, in which gender is captured under the second goal of equity and equal participation (Department of National Planning and Monitoring, 2015).

The Australian aid branch is one of the four branches of the foreign aid division of DNPM. Australian aid (DFAT) is the biggest grant donor in PNG. Annually, a number of high profile meetings and discussions take place between both governments around Australian aid coordination. The nature of Australian aid in PNG is not limited to development cooperation but other areas as well:

The Australian aid coordination is not only limited to 'development cooperation' but is also with Police, Defence, plus other MOU arrangements that exist between countries. (Interview, Government Official, June 2017)

The nature of support PNG receives from Australia is through programme support. Prior to this arrangement, it was through budget support. However, PNG has requested to revert to budget support but this request was not received well by Australia in the March 2017 meeting: 
At this year's ministerial forum in March, PNG asked Australia for 'budget support'. This request was not received well by Australia. They are more reserved. Due to the past experiences with PNG's fiscal systems. PNG has to create an enabling environment so development partners can trust government to provide funding. (Interview, Government Official, June 2017)

It is important that the Development Cooperation Policy is fully understood by both government officials and government ministers in PNG. Also noting that Australia is a sovereign nation and has its own guidelines/policies around development cooperation to adhere to. PNG has to create an environment that is conducive for the donor to provide such assistance.

\subsubsection{National Policy for Women and Gender Equality 2011-15}

As mentioned earlier, the National Policy for Women and Gender Equality is based on GAD and uses a cross-cutting approach that aligns with other government policies. Its objective is to create an enabling policy environment that translates government's commitment to gender equality into action through the establishment of policies, programmes and structures. It also seeks to empower women and transform gender relations in all aspects of work, and at all government levels and in the wider community. The implementation strategy is emphasised through 'working in partnership' with key partners: Office of the Development of Women; National Council of Women (NCW); national government departments; provincial governments; civil society organisations; and development partners (Department of Community Development, 2011).

As indicated by the policy, provincial governments are expected to implement this policy by way by having provincial and district plans being 'inclusive' of gender and women's empowerment initiatives. However, this is difficult, as one participant shared:

Oro province is yet to fully address gender in its Provincial and District (Sohe and Ijitivari) plans. There are other factors like funding and resource allocation that make it difficult to implement this policy. (Interview, OPA Staff, July 2017)

There is a huge disconnect between the Department of Community Development (national office) and the provincial office (Division of Community Development) in Popondetta (Oro province). For example: 
National Gender Policy is yet to reach the provincial and district level. I am the adviser of the Community Development Division but I don't have a copy of this policy. (Interview, OPA Staff, July 2017)

Lack of funding and human resources to implement the policy was another reason why the gender policy is not being implemented effectively in Oro province:

Supporting nine Local-Level Governments (LLG) is difficult. Manpower and resources are lacking. For example, I don't know what happens in Kira District on gender and women's empowerment work. There are no Community Development Officers (CDO) in the nine LLGs which makes it hard for monitoring and reporting of progress. Funding must also be tied to these policies with adequate resources. There are no staff to implement the policy - human resources is just lacking. (Interview, OPA Staff, July 2017)

The decentralisation process has not been effectively carried out to date. There is still lack of awareness of this policy, even though the policy states 'extensive' awareness and consultation was carried out at subnational level prior to 2011 (Department of Community Development, 2011). The trickledown effect has not been successful to date, although the policy has since expired in 2015, and is up for review in 2017. When the policy came into effect in 2011, there were no specific awareness activities conducted in Oro province to highlight its purpose and usefulness, as well as develop a realistic plan for effective implementation for the Division of Community Development staff, under OPA.

\subsubsection{Gender Equality and Social Inclusion Policy 2013-15}

The Gender Equality and Social Inclusion (GESI) policy was designed to assist all public servants at national and subnational level to embrace gender equality and social inclusion principles of respect, equity and diversity. It sets a framework of gender equality and social inclusion practices in the workplace and is consistent with the National Policy for Gender Equality and Women 2011-15. The policy has a twofold implementation approach: the first approach focuses on 'internal' GESI values principles in the workplace within all public service organisations; and the second approach is 'external' in nature. It embraces GESI values and principles in the design and delivery of all government-run services to all citizens. The purpose of this policy was to set the guidelines for all public servants in the introduction of GESI principles into policy and practice as part of service 
delivery outcomes for the national public service (Department of Personnel Management, 2013).

The GESI policy was developed with support from the former Australian Aid (now DFAT). Australian Aid also provided funding and technical expertise for the pilot phase that was implemented in specific key government agencies and two provincial administrations: West New Britain and Western. There are three programmes that emanated from the policy: male advocacy network; women in leadership and GESI community of practice.

In general, implementation of the policy has been slow from 2015-16. Leadership and capacity was lacking at that time and it needed someone to drive it. In 2017, we are going to reprioritise the policy and have mechanisms in place to further implement this policy through the review process. The updated policy must reflect current changes in policy and add new concepts and insights to bring more value to the policy. Also, this review will look to incorporate and reflect on the regional (Pacific) objectives around GESI. (Interview, Government Official, June 2017)

DFAT supported the development of the GESI Policy and its pilot phase in two provincial administrations however; there were challenges in the policy implementation afterwards: DFAT was the main development partner in driving this policy for four years, especially in the development stage of the policy and the pilot phase. With the implementation of the policy, they (DFAT) were hesitant in supporting our work plans. The biggest challenge for GESI implementation is financial capacity. Also there is no clear communication to us from DFAT highlighting the scope of their work to support GoPNG agencies in the GESI space. (Interview, Government Official, June 2017)

While it is a positive sign that a policy review is due, fundamental issues around the policy implementation must be taken into account such as funding, training of personnel, and awareness of GESI issues. These issues must be taken considered at all levels of government, especially at subnational levels. Lessons can be learnt from the pilot phase in two provincial administrations which can inform the new design of the revised policy in 2017. 
Sohe District in Oro province is one of DFAT's target districts of support for its former Provincial and Local-Level Government Programme (PLGP) and the current PNG Governance Facility (PGF). While DPM is the official custodian of the GESI Policy, implementation of the GESI policy was driven by DFAT at that time due to funding and resource constraints experienced by DPM.

Not much has been done in Oro apart from the sensitisation workshop in 2015. No follow up sessions have been done. The reason being that implementation in Oro is driven by DFAT and not properly organised. There is no GESI focal point person in the province to take ownership of the GESI work. (Interview, Government Official, June 2017)

There seem to be issues around ownership of the GESI Policy in Oro province. DPM, OPA and DFAT need to be clear who takes full ownership of the policy in Oro province, going forward.

\subsection{Australia's DFAT Gender Equality and Women's Empowerment Strategy}

DFAT's Gender Equality and Women's Empowerment Strategy was launched in June 2014, and officially released in February 2016 to be implemented within Australia and abroad. The strategy outlines the Australian government's efforts in strengthening and engaging in policy dialogue while upholding Australia's international reputation as a global leader on gender equality and women's empowerment (Department of Foreign Affairs and Trade, 2016). As Julie Bishop, Australian Minister of Foreign Affairs notes:

It establishes that gender equality and women's empowerment are a priority to development, and sets an ambitious target requiring that eighty percent of all Australia's aid, regardless of objectives, are performed effectively in promoting gender equality (Bishop, as cited by DFAT, 2016, p. 3).

The strategy has three priorities with respect to gender equality and women's empowerment: enhancing women's voice in decision-making, leadership and peacebuilding; promoting women's economic empowerment; and ending violence against women. This strategy applies across all areas of work undertaken by DFAT in Australia and internationally. It also uses a twin-track approach to be effective in achieving gender equality and women's empowerment. The first approach tries to address challenging 
gender inequalities by ensuring development programmes promote gender equality and women's empowerment as an investment priority. The second approach requires the integration of gender equality across all areas and sectors where Australia provides ODA (Department of Foreign Affairs and Trade, 2016).

According to DFAT's Aid Programme Performance Report for PNG for the period of 2016-17, gender equality and women's empowerment in PNG is challenging, yet a critical cross-cutting issue for Australia's engagement in PNG. This engagement is guided by the Gender Action Plan 2015-20 of the Australian High Commission in Port Moresby. The performance of Australia's support for gender equality in PNG is measured through the 'quality of the implementation' of investments, and the amount spent on gender equality activities (Department of Foreign Affairs and Trade, 2017).

In 2016-17, Australian's development assistance to PNG met the strategic target that 80 percent of investments effectively addressed gender issues, measured through Aid Quality Check ratings, demonstrating the continuing focus on achieving tangible results for PNG women and girls. However, this ranking is lower than the previous years: 86 percent in 2015-16; compared to 92 percent in 2014-15. It was noted that there needs to be rigorous assessments of the impact of investments in 2016-17 and a renewed focus on effective integration of gender equality through investments. Australia will spend \$58 million over five years (2014-19) on specific activities related to gender equality and women's empowerment in PNG through the Pacific Women Shaping Pacific Development Programme (Department of Foreign Affairs and Trade, 2017).

The Pacific Women Shaping Pacific Development Programme's PNG office supports both private sector and government agencies through a bilateral agreement. It supports ten provinces. Unfortunately, Oro province is not one of them:

Women's economic empowerment component is done through agriculture and private sector is done through business coalitions. We support ten provinces: East Sepik; West Sepik; Eastern Highlands: Western Highlands; Jiwaka; Simbu; Autonomous Region of Bougainville; East New Britain; NCD; and Central. (Interview, Programme Staff, August 2017) 


\subsubsection{DFAT's Gender Equality and Women's Empowerment Strategy Implemented in PNG}

Given that PNG receives ODA from Australia, this strategy is relevant to the work that DFAT undertakes in PNG. Since the strategy was only officially released in February 2016, there is yet no clear direction in terms of how the strategy can be 'customised' or 'translated' to suit the unique PNG context or be implemented within the different DFAT programmes in PNG:

There is no specific PNG Gender Strategy but an in-house document called Gender Action Plan 2015-20 which is specifically for High Commission staff. This policy is linked to the DFAT Gender Strategy and is used to report to Canberra. This document is not for public use. (Interview, Gender Team - Australian High Commission, June 2017)

The DFAT Gender Strategy is taken seriously by mainstreaming gender in all DFAT programmes in PNG. The gender programme is delivered by Pacific Women and is the only DFAT programme that has an overall gender focus and aligns with the DFAT Gender Strategy. (Interview, Gender Team - Australian High Commission, June 2017)

Overall, there is still lack of clarity in implementation of DFAT's Gender Equality and Women's Empowerment Strategy within the generalist programmes. Programme staff expressed the need for clarity given this strategy is an international document that is being used in PNG. The implementation of this strategy in PNG can be problematic if the recipient government is not clear in terms of how this strategy can contribute to PNG's existing gender and women's empowerment policies:

This strategy must align with the respective government's strategy on gender and women's empowerment or it will just be seen as an influencing advocacy tool. (Interview, Programme Staff, August 2017)

Programmes need to be clear about this strategy regardless of their focus. Staff need to be oriented on the use of this strategy and how it links into their programme activities and their overall programme outcomes:

The document should somehow inform DFAT and the partner government. It can be a real challenge to implement such a strategy in all programmes that are not 'gender' specific. I am yet to see how this strategy translates into realistic work 
steams. Are there instructions for implementation? The biggest challenge is trying to get 80 per cent balance for gender work. It seems a coordinated effort is lacking in the gender space. (Interview, Programme Staff, August 2017)

\subsubsection{DFAT Support to Oro Province}

The Australian government's support to Oro province is currently through four generalist programmes. There are no specific gender programmes that are implemented in the province.

There is no specific gender programme that is implemented in Oro province currently. However, there are four programmes that support the Province. It would be interesting to find out what happens on the ground. We work at national level (upstream) looking at designs, budgets and evaluations but rarely go down to understand what has trickled-down and remained with the local communities as a result of this support. (Interview, Gender Team - Australian High Commission, June 2017)

Without a gender specific programme in Oro province, DFAT's other four generalist programmes are expected to include gender in their programme regardless of the main objective of their programmes.

\subsubsection{PNG Governance Facility (PGF)}

All governance-focused programmes in PNG come under the PGF since its inception in June 2016. Prior to PGF, the Provincial and Local-Level Government Programme (PLGP) was supporting Oro province with improved decentralisation of core government services within OPA and Sohe District. PLGP support was provided through nationalbased advisers who worked closely with both provincial and district level staff to build capacity and strengthen government systems, thus contributing to ownership of subnational decentralisation processes. PGF has now taken over this role in its current phase. (PGF Investment Design Document, 2015). A participant expressed the following view in regard to PLGP's gender work:

Support to Oro around gender is not consistent like the Sub National Strategy $(S N S)^{5}$ days. With the passing of the late adviser in late 2016, work has been

\footnotetext{
${ }^{5}$ SNS was a former programme of the then Australian Aid (AusAid). It was in operation from 2007-2011 and supported OPA. 
stalled at OPA and Sohe District Administration. Some work in light of gender under this program in Oro province was through the human resources processes, corporate plans, training of local farmers through ACIAR ${ }^{6}$, business acumen training in partnership with $\mathrm{NARI}^{7}$ and Sohe District. Two phases of these training sessions have been completed. The third is yet to be done. Not much was done in terms of the sensitisation programs around gender for Oro Provincial Administration. (Interview, Programme Staff, August 2017)

The programme (PLGP) also worked closely with the local politician, the then MP for Sohe. She had plans for gender and women's empowerment initiatives and made the following arrangements:

The PLGP program also worked closely with the former member for Sohe, Delilah Gore, to support women in Sohe district. PGK 500,000 ${ }^{8}$ was committed to women but these monies were not released by $N D B^{9}$ as processes to acquire this money was not thoroughly completed. (Interview, Programme Staff, August 2017)

With PGF taking over from where PLGP left in mid-2016, there is more to be done with support to Sohe District and OPA in the area of gender and women's empowerment.

\subsubsection{Kokoda Initiative (KI)}

KI comes under PGF but its focus is at the community level through sustainably developing and protecting the Kokoda Trail ${ }^{10}$ and its surrounding areas. The programme supports livelihood improvement programmes for landowners and communities through health, education, and sanitation activities. It also supports income generation activities as well. All communities along this track benefit to an extent through this programme:

Health and education facilities along the track have been supported. For example, for health, KI supported Kokoda Hospital, Efogi Health Centre and Menari Health Centre. This was through infrastructure improvements to the health centre and staff houses. KI also supported elementary and primary schools. It is still hard to measure if more girls are empowered as a result of increased enrolment

\footnotetext{
${ }^{6}$ Australian Centre for International Agricultural Research

${ }^{7}$ National Agricultural Research Institute

8 PGK 500,000 is equivalent to NZD 208,191

${ }^{9}$ National Development Bank

${ }^{10}$ Kokoda Trail is a famous WW2 battle field that holds historical significance to Australia and PNG. Kokoda Trail starts from Sogeri LLG (Local Level Government) in Central province and ends at Kokoda LLG in Oro province.
} 
to attend schools as a result of new classrooms being built. We will have to try and find that out. (Interview, Programme Staff, August 2017)

\subsubsection{Justice Services and Stability for Development Programme}

Justice Services and Stability for Development programme (JSS4D) is the fourth phase of the Law and Justice Programme for DFAT. There are four components of this current phase: community safety and security; addressing family and sexual violence; law and justice services; and anti-corruption (JSS4D Design Document, 2015). The programme's involvement with Oro province goes back to February 2013 when an adviser was placed in the province. The programme's work in Oro province covers the following areas: community safety; improving coordination of OPA with key service delivery committees and the provincial law and justice committee; increasing awareness of local people on their rights; creating local solutions for local problems around law and justice; and supporting the management of the law and justice sector. The programme takes into account the DFAT Gender Equality and Women's Empowerment Strategy through components of its work:

In our gender component work in Oro, women parolees, probationers and exprisoners attend the Start Your Business Training. Fifteen women have been trained so far in December, 2016. They have been able to open their bank accounts and save. Women came from Higaturu, Oro Bay, Popondetta Urban and Afore LLGs. A further awareness programme for 80 women has been budgeted for in my work plan for the remainder of the year. After elections we will commence this. (Interview, Programme Staff, July 2017)

Support to women given by this programme is increasing. That is a positive indication of the trickle-down effect of DFAT's Gender Equality and Women's Empowerment Strategy.

\subsubsection{Transport Sector Support Programme}

The Transport Sector Support Programme (TSSP) is another DFAT programme that supported Oro province between 2014 and 2016 through the reconstruction of four old bridges that were washed away when Cyclone Guba hit in 2007. Eroro, Girua, Ambogo 
and Kumusi bridges were reconstructed through funding from the TSSP programme (TSSP Oro Bridges Reconstruction Project Report, 2017).

I am happy that the new bridges are built by Australia but still the distance to town makes it costly and it depends if I sell all my food in one day. (Interview, Local Woman - Kokoda LLG, July 2017)

An impact study has been planned to assess the positive and negative impacts of the Oro bridges reconstruction project on the local economy, private sector, and communities. This was expected to commence in August 2017. This study will also include how the bridges have contributed to supporting women's empowerment in Oro province.

\subsection{Ownership of Policies}

\subsubsection{DFAT Gender and Women's Empowerment Strategy in PNG}

The DFAT's Gender Equality and Women's Empowerment Strategy is an international document. One that belongs to the Australian government and is managed by DFAT, both in Australia and overseas. In PNG, this document is managed by the Australian High Commission, through the gender team. The policy is then expected to be implemented throughout all DFAT programmes:

DFAT policy is taken seriously and has a twin-track approach to mainstreaming gender across the larger investment programmes. Compared to other countries, DFAT in PNG is doing very well in benefiting women and girls. (Interview, Gender Team - Australian High Commission, June 2017)

Depending on the nature of the programme, programmes will endeavour to contribute to gender and women's empowerment within the scope of their objectives.

The JSS4D Programme has taken into account DFAT's Gender Strategy. Family and sexual violence and the empowerment of women are some of our focuses of work. (Interview, Programme Staff, July 2017)

\subsection{Collaboration and Partnership}

It is important that collaborations and partnerships are used effectively by government agencies at national and provincial level to be able to achieve their mandated objectives 
and outcomes. Also, DFAT can use these networks to implement their programmes nationally and sub-nationally.

\subsubsection{The National Policy for Women and Gender Equality}

As the National Policy for Women and Gender Equality states, a major emphasis of implementation of this policy is through working in partnerships (Department of Community Development, 2011). The Division of Community Development in Oro province, under OPA relies heavily on its partners as an approach to implement its key activities around gender and women's empowerment. For example:

Currently what is done is to use partnerships with NGOs and other development partners to outreach to rural areas. We work with the International Organisation for Migration (IOM), Red Cross, Law and Justice Program and Anglicare. The Law and Justice Program has helped Popondetta Urban Youths. In the past we got help from Strongim Pipol Strongim Neisen $(S P S N)^{11}$ for community development projects. They funded ten projects and Oro did well. (Interview, OPA Staff, July 2017)

The International Organisation for Migration (IOM) is an international organisation that supports communities in Oro province around community-based disaster reduction. They work in partnership with the Division of Community Development and the Disaster Office of OPA:

We support 14 communities in Oro and 19,963 people benefit from our programmes. In some communities, women are taking the lead in deciding where water catchment systems should go. For example, in meeting minutes, women are moving the motion to agree on the location of water catchments. (Interview, IOM Staff - Popondetta, July 2017)

\subsubsection{DFAT Programmes to Work Collaboratively in Oro Province}

Without a specific PNG gender strategy or an overall framework that brings together DFAT programmes in terms of gender, there is room for some collaboration and synergy within the different programmes. These programmes are not 'gender' specific but have

\footnotetext{
11 SPSN is another former Australian aid programme.
} 
elements of gender components embedded in them. To maximise their contributions, they could look at the possibility of working collaboratively with other programmes and their key stakeholders in Oro province. This perspective was raised in an interview with programme staff:

In passing, we heard from the JSS4D Programme staff that they were coming to do some work in Kokoda with village court officials. They wanted to speak to us about linkages in our communities. But we haven't taken this collaboration any further than that. This could be an opportunity to tag team and work together - instead of working in silos. (Interview, Programme Staff, August 2017)

\subsubsection{DFAT's Pacific Women Programme}

DFAT's Gender Programme, Pacific Women (PNG Office), works closely with its partners in the private sector, within government, business community and with NGOs to support ten provinces it works in:

The programme works with over thirty plus partners, research institutions and universities. It is an innovative programme that tries to encompass family, and a team approach around sustainability and empowerment of women. Not much funding is given to this programme but we play an important role around coordination among partners, and learning and sharing of experiences. Through the 'Yumi Kirapim Sensis'12 approach, the programme intends to reach out to remote areas in PNG. We also try to learn from the Pacific approach, especially the Melanesian context. (Interview, Programme Staff, August 2017)

It is positive that DFAT's gender programme is being inclusive and has involved relevant partners in its effort to support gender and women's empowerment in PNG, especially in its target ten provinces.

\subsection{Notions of Women's Empowerment in Oro Province}

The notion of empowerment is often a contested one. Women's empowerment can encompass different meaning and understandings by individuals and groups in Oro

\footnotetext{
12 Yumi kirapim senis is the Tokpisin (national language) equivalent for bringing change. An approach that Pacific Women uses in PNG
} 
province. Empowerment should be defined by the local women themselves and not by outsiders.

\subsubsection{Targeted Training for Women to Sustain Women's Empowerment Efforts}

Participants in this research felt that while it was good to offer women training to advance their skills and knowledge, it should be tailored to their needs and the outcome of their training should be sustained. For example:

Female staff in OPA need exposure. Empowerment should be targeted at specialist training and targeted to the work they are currently doing so when they return to the host organisation they are able to put those skills to use and increase their chances of employment. What is the use of one-week short term training? It should be a few months. Also encouraging being on attachments with other provincial administrations, who are performing well to learn from them. Two female staff have been to Australia on short term scholarships to do a Certificate in Project Management course. This is an example of the targeted training that was supported by Australian aid. (Interview, OPA Staff, July 2017)

A recipient of a short-term training scholarship in Australia, felt that the six weeks long short-term course on Project Management in Melbourne's Bendigo Tafe was empowering. For example:

After I completed my course in 2015, I returned to Oro Provincial Administration and implemented two individual projects. My first project was creating space at the HR Division so staff can come together and discuss issues and not sit at their desks the whole day. This will save money for the division to try to hire venues for meeting. My other project was to create a storage space for keeping old HR files because confidential information about staff in the public service in Oro province were stored there. The first project was done ok but project two is still in progress but slow. I feel empowered to have this training and the support from Bendigo Tafe to make sure I carry out my projects. But I need the help of my boss to help me support some of my decisions to help with my projects. (Interview, OPA Staff, July 2017) 
Training should not only target OPA staff but also those at district and Local Level Government (LLG) level. Often training is centred on the provincial headquarters and is attended by staff of OPA and those at lower levels (Districts and LLGs) are missed out.

Training should also target LLG managers and not just provincial administration staff. They need to be informed of the changes in government systems and structures. Information needs to trickle down. (Interview, OPA Staff, July 2017)

Specific training on budget and finance has benefited OPA staff and improved Oro province rankings in the National Economic and Fiscal Commission (NEFC) for the first time in years:

Oro province improved significantly after support was given by PLGP for the 3Pager Budget System. For the first time, Oro came second in 2016 in the NEFC score card rankings. Many staff at Oro Provincial Administration have taken on this skill and it's improving their work. As a female staff member and senior auditor for Oro Provincial Administration, I feel empowered attending this training. I am one of the few female staff who has a bachelor's degree and this qualification helps me articulate new training that is provided in my area of auditing and finance. (Interview, OPA Staff, July 2017)

One participant shared an example of targeted training to suit participants' needs, which contributed to empowering men and women:

As a community corrections officer, my work involves working with parolees, probationers and ex-prisoners. Through DFAT support, our office was able to conduct Start Your Own Business (SYOB) training for parolees, probationers and ex-prisoners to help them start their business. One of our successful stories is one of the ex-prisoners. Her name is Maxine. She took up our training on SYOB and is successfully running her guesthouse in Oro Bay. Follow up training on financial management has been given to participants to also help them manage their business. (Interview, Community Corrections Officer, July 2017) 


\subsubsection{Community-Level Empowerment}

Participants felt that empowerment initiatives, whether they be donor or government funded, should target women at the community level, as most women at local level are disadvantaged to an extent and need that level of support to better their lives. A mother from Kokoda LLG had this to share regarding the struggle of bringing her vegetables into the Popondetta town market to sell:

Not many women come to Popondetta town from Kokoda to sell their food. Most go to Kokoda market because it is closer than coming to Popondetta town. I pay big money to bring my food to Popondetta market. It is 40 kina to come to town and go back on a PMV truck and 5 Kina for each bag of food I bring to sell in the market. (Interview, Local Woman-Kokoda LLG, July 2017)

The Kokoda Initiative (KI) is the DFAT-funded programme that targets communities along the Kokoda Trail in providing health and education services to schools and health facilities. Even though it is not a gender specific programme, KI support has helped women and girls in empowering them:

The Officer in Charge (OIC) of Kokoda Hospital has been receiving support from KI since 2008. She has received a lot of training and accreditations and attends all nursing conferences annually. She is also in charge of the village health volunteers in Kokoda hospital. Also, the OIC for Efogi Health Centre and Sogeri Health Centre are females. They also have received support from KI to be where they are now. (Interview, Programme Staff, August 2017)

Village Health Volunteers (VHV) are a group of volunteers who basically have left school after completing their high school (Grade Ten). They undergo six weeks of training before they become certified VHV. They do outreach to the rural areas of Kokoda and Sogeri. They carry out activities such as supporting expectant mothers in being village birth attendants, conduct antenatal health awareness, and do general health and HIV/AIDS awareness to communities. VHVs are actually part of the National Department of Health organisation structure but because they are further down the line, they are often forgotten and not utilised at all. This is where KI comes into support and fills this gap. (Interview, Programme Staff, August 2017) 
KI has also supported more than fifty (50) VHVs to open their bank accounts so they can be able to save their allowances. According to Post Courier Newspaper (2016, p. 20):

Community and Public Health Officers of KI indicated that volunteers lived in villages and had no access to banks and public services and would have not have been likely to open bank accounts without the help of the programme. For most locals this is new to them and they are excited. Now they can learn to save and manage their money wisely. This will also benefit our program officers going into communities to do work. We don't have to risk carrying cash like we did in the past.

However, participants at the community level expressed that support from government for women's empowerment is still lacking. There is limited funding through the Division for Community Development in OPA. This makes it even harder to support any LLG or ward activities for women's empowerment. For example:

The Community Development Division is the most poorly funded division by far in Oro Provincial Administration. Least priority is given to this division. There are only two community development staff and I am the adviser, who has been 'acting' in this position for three years now. I don't know how else to support districts, LLGs and wards for gender and women's empowerment work. (Interview, OPA Staff, July 2017)

Members of Ward 10 - Council of Women expressed their struggles as they embarked on strengthening women's empowerment initiatives within their community:

We don't have any help now from the government so what we plan to do is talk to our Ward 10 mothers and daughters to see how we can support ourselves through economic development. We have our 'mama lus'13 which can help us. We just need to know how to save our money properly. There are 10 roads in Sorovi Ward 10 area. So if all 10 small road communities can work together, we can help each other. (Interview, Ward 10 member, July 2017)

${ }^{13}$ Loose oil palm fruits that fall off the oil palm bunch that women collect and sell for an income. 


\subsubsection{Local Women's Organisations as Vehicles for Change}

The National Council of Women (NCW), through its provincial branch (Provincial Council of Women) in Oro province, is expected to empower women at all levels as per its mandate which is affirmed through the National Council of Women Act 2013. However, the organisation still faces challenges in its effort to carry out its mandated duty. For example:

There is no funding for this organisation. It is hard for us to conduct any activities because there is no funding from government. Now we are asking women in Oro to pay an annual membership fee of 10 Kina. Out of the 10 kina, 2 Kina is taken out for admin work for the Provincial Council of Women work. Eight kina remains at ward level and it's up to the ward executives how they will use the 8 Kina for their annual activities. We are encouraging women at ward level to engage in Small and Medium-size Enterprise (SME) so they earn a bit of money to help themselves. It will be good if we align our plans with the LLG and district plans so we get some funding from our open members. I just took office so I am trying to establish myself and my provincial executives before we can roll out any activities. I'm sure support may come but first we have to put our house in order and get our internal process right. (Interview, President of Oro Provincial CW, July 2017)

While there are number of ward level Council of Women $(\mathrm{CW})$ branches in Oro province, I particularly make reference to Ward 10, which is made up of Sorovi and surrounding areas, in the Popondetta Urban LLG in Ijivitari District, Oro province. Since the formation of the new executives of Ward 10 CW in March 2017, not much has been done. Funding is still a huge impediment as there is no direct funding from the government or other sources. Despite this challenge, the executives and some members remain positive that they will make this association work for all the women in their locality. For example:

Women in Ward 10 belong to church groups and so the association can work together with these church groups to bring women together. Even though this association is new to Sorovi, women want to see change and they are excited to work together. (Interview, President of Ward 10 CW, July 2017)

We as women leaders must start being the role models at home, within our families. I need to be a good leader for my children and lead by example. It reflects 
the kind of parent you are. For example, the issue of home brew consumption by youths is taking over our community. We as mothers, have to do our part in shaping our children's behaviour. Issues should be solved at family level. Now that is not happening so we see a lot of youths in the community who have gotten out of hand. (Interview, Member of Ward 10 CW, July 2017)

Council of Women as an organisation has been in operation for 40 years in $P N G$ but in Ward 10, it only just started. One of our main tasks is to know how many women are willing to be part of this network. We need to base our core work on the population of women in Ward 10 so we can try to support their needs. (Interview, Member of Ward 10 CW, July 2017)

Because we are just starting, we do not have many things to show for the work of the association. But our plan for the future is that all our women in this Ward 10 are supported. Ward 10 is known for its oil palm blocks and women have access to it which is good. Training can be provided to them so they can manage their income from the oil palm harvest. It would be good if we had an office to work from. At the moment we just meet at an executive member's home or at the community centre at Sorovi, if we can find a nice spot under the trees. (Interview, Vice President of Ward 10 CW, July 2017)

It is positive to note that these local women's group is determined to make a difference in their community. Without much support from the government or the NCW through the Provincial Council of Women, Ward 10 Council of Women is determined to reach out and support women in the Ward 10 area of Popopndetta Urban LLG, Oro province.

\subsection{Summary}

The DFAT Gender Equality and Women's Empowerment Strategy was only recently launched in February 2016, and is still yet to be fully implemented in PNG, and Oro province specifically. The strategy is still not fully understood even though it is of utmost relevance across DFAT programmes and their stakeholders at national and provincial level in PNG. The PNG government must also carry out its mandated duty and implement its own gender policies at the subnational level, including in Oro province. There is a great need for both the recipient government and donors (including DFAT) to work collaboratively to address gender issues. The Oro Provincial Council of Women branch is an organisation that can do more for women in Oro province and should be supported

Camilla Ethel Angoro - Master's Thesis - Victoria University of Wellington 
by both the political leaders and government agencies to carry out their work and reach out to all rural women and communities. 


\section{Chapter Six: Discussion of Results}

\subsection{Introduction}

The aim of this study was to understand the contributions of Australia's Gender Equality and Women's Empowerment Strategy to empowering local women in Oro province of PNG. My research used a qualitative study involving twenty-five (25) research participants through 19 semi-structured interviews and a focus group discussion consisting of six participants. Participants were from three groups: DFAT officials, PNG government officials, and a local women's group. The four research questions that the study sought to understand were: 'How has DFAT's Gender Equality and Women's Empowerment Strategy contributed to the empowerment of women in Oro province?', 'What is the level of collaboration with the PNG government to support DFAT's Gender Equality and Women's Empowerment Strategy?', 'What are the contributions of government officials and local politicians in implementing women's empowerment initiatives in Oro province?', and 'How does the DFAT Gender Equality and Women's Empowerment Strategy support the work of women's organisations in Oro province?. This chapter will be organised around the main themes from the findings chapter: implementation, power, ownership, communication, collaboration and partnership, and empowerment. The chapter also discusses the implications of the findings, limitations of the research approach, and makes recommendations for future research.

\subsection{Implementation of Gender Policies at Subnational Level}

The findings of this research indicated some issues around implementation of DFAT's Gender Equality and Women's Empowerment Strategy. Firstly, local programmes are not fully aware of DFAT's 2016 Gender Strategy, or the implementation mechanisms that are supposed to exist within gender components of each programme. However, it must be noted that not all programmes are gender specific in nature, which creates a certain level of complexity for implementing a strategy. Generalist programmes have to be innovative and creative in thinking about how their programme activities/outputs/outcomes will impact on and contribute to gender and women's empowerment. For example: how does an infrastructure programme that builds bridges and roads contribute to gender and women's empowerment in the local area? It is then the responsibility of these programmes to reflect on how these activities contribute to gender and women's empowerment. With DFAT's Gender Equality and Women's Empowerment Strategy calling for 80 percent of 
programmes to be inclusive of gender, this should enable ways for programmes to be innovative about gender inclusivity in their activity planning, implementation and monitoring; ultimately contributing to gender equality and women's empowerment at the subnational level. While the strategy aims to bring more gender focus to the way DFAT provides development assistance to PNG, there is still room for work around the clarity of this strategy as it is being implemented in PNG, and the specific provinces that DFAT supports.

The key issues with the implementation of PNG's gender policies (GESI and National Policy for Women and Gender Equality) in Oro province are tied to the simple fact that there is no funding or resources tied to these policies. While these policies indicate that provincial administrations need to support implementation, they are limited in their ability to separately fund and provide resources for implementation. OPA only has limited budget for its mandated tasks, and this resulted in both policies not being implemented in Oro province. Another issue is that the terms of these policies have now lapsed and are due to be updated, but it is still unclear at this stage when these updates will commence. However, it important that these future updates capture the essence of the reality of the gender issues, and opportunities and achievements (at the subnational level). Too often, it seems key documents are designed from Waigani (the main government hub) and lack the voice of the local people. A recent research by Aiafi (2017) highlights the need for Pacific Island Countries (PIC) to have home-grown policies, and these policies should emerge from the local people. PNG is no different. If local people are part of the policy development process and have their voices reflected in these policies, they will take ownership of implementation, especially Provincial Administrations and their Divisions of Community Development, as well as local women's groups, churches, NGOs and civil society organisations. Another research by Campbell and Teghtsoonian (2010) has indicated that donors support recipient governments in terms of funding; however, the onus remains with the state to channel these funds to support women. The support given by DFAT to assist with gender policies does not necessarily trickle down to rural women, if the recipient government's mechanisms/systems are not in place to channel these funds to activities that support rural women. Overall, both gender policies have failed to support rural women, especially in Oro province. 


\subsection{Power}

The notion of power was recognised within the different participant groups during the interviews. My research included the governments of two countries: DFAT representing the Australian government; and DPM, DNPM, and the Department of Community Development representing the PNG government at national level, and OPA at subnational level. Foucault (1982, as cited in Panda, 2000) describes power as relational and something that exists only in its exercise. Power was seen to be in existence firstly through DFAT being the donor. They had elements of power at the Australian High Commission through the gender team, for example, being custodians of DFAT's Gender Equality and Women's Empowerment Strategy in PNG. An example of the way that power is experienced and felt was experienced directly during the course of this research when DFAT officials were interviewed by the researcher. The interview was conducted at the Australian High Commission office and this office is on land that has diplomatic immunity for Australia. During the interview, the researcher felt the power shifted to them during certain periods of the interview. This was primarily because the gender team was made up of senior DFAT officials and the researcher was a student. Also, during interviews with DFAT programme staff, certain staff had power given their seniority in the programme. English (2012) highlights that post-structuralism sees power as fluid and held by everyone. This was not necessarily the case as depicted by the first group of participants in my research. Overall, DFAT holds more power given they are the biggest bilateral donor in PNG and the research is primarily centred around their support to women's empowerment.

The PNG government agencies at the national level have power due to their mandated responsibilities as line agencies within the government. They also are custodians of key gender and development policies. Therefore, it is expected that they hold power. Also, during selection of participants for interviews, the researcher was asked to seek formal approvals from heads of two departments and that protocols in conducting research in their organisations had to be followed. This demonstrates the level of power that they held, in effect being able to prevent or limit the research. As an external researcher, I had to adhere to protocols and submit a letter seeking approval for my research (see Appendix 3 and Appendix 4). OPA at the subnational level also holds elements of power as the organisation responsible for government services in the Oro province.

It was evident that power was also existent between the different participant groups. There was more power within the DFAT official group. Because the study was primarily 
focused on DFAT, it seemed they held most power due to their programmes being implemented in Oro province and also the fact that they were the donor. The power dynamics changed slightly within the government group at national level compared to the DFAT group. This change in power dynamics was due to the kind of working relationship that these government agencies had with the donor (DFAT). In addition, the government agencies were the mandated agencies for gender policies; therefore, it increased their power base. At subnational level, OPA had more power than the local women's group (Ward 10 Council of Women). OPA had more power because they were responsible for decentralised government services to the province. At the community level, Ward 10 Council of Women had elements of power because they are affiliated to NCW, but are yet to establish themselves and build that power base through the work they do in their community.

Specifically, looking at my research question regarding the collaboration between the PNG government and DFAT in implementing gender strategies (both donor and recipient government), there can be instances of a shift in power for political and diplomatic reasons. However, these shifts in power can be carefully navigated to support gender and women's empowerment in PNG.

\subsection{Ownership}

The study highlighted issues around ownership of key gender documents in their quest to support women's empowerment at subnational level and more specifically in Oro province: the specific gender documents were DFAT's Gender Equality and Women's Empowerment Strategy, and PNG's National Policy for Women and Gender 2011-15 and Gender Equality and Social Inclusion (GESI) policy 2013-15.

DFAT's Gender Equality and Women's Empowerment Strategy is an international document used by DFAT in PNG to support gender and women's empowerment initiatives by way of programme support. There are a number of key organisations that this strategy must filter through before it gets to support local women in Oro province. The Australian High Commission in Port Moresby, through its gender team, provides oversight of all programmes in light of gender and women's empowerment. The next group are the implementing agencies and partners contracted by DFAT to implement specific programmes; for example, Coffey International Development, Cardno, and Abt Associates. These agencies are expected to adhere to DFAT's Gender Equality and 
Women's Empowerment Strategy as per their contractual obligations. However, they can have their own gender objective as an independent organisation. This can create elements of complexity as they navigate between two gender lenses. PNG government is another stakeholder within the group that the strategy has to filter through as well. This can happen at different levels depending on the nature of the programme and its beneficiaries. Also, notable is that the DFAT strategy in essence is being used in PNG to support the efforts of the recipient government. This can be an opportunity for DFAT to contribute to PNG's gender policies and general support to the area of gender equality and women's empowerment. However, there can be issues around the level of support DFAT can give, without undermining the autonomy of the recipient government's agencies that are tasked to implement their own gender policies.

At the programme level, it is important that all staff (general and gender teams) be clear about DFAT's Gender Equality and Women's Empowerment Strategy, and what it means to them within the nature of their work. Not all programmes are gender specific in nature and, therefore, this difference can cause programmes to lose gender focus, despite the strategy calling for eighty percent gender focus regardless of objective (DFAT, 2016). Also, working with programme stakeholders and beneficiaries, there should be elements of clarity on what constitutes a gender equality and women's empowerment focus within these programmes. Working in the gender space in PNG, and more specifically around women's empowerment, DFAT's support can be mistaken for being donor-driven only. This can happen if stakeholders and beneficiaries are not given an opportunity to define what constitutes the nature of support for women's empowerment. This can be addressed at the activity level when designing activities that are context and location specific. For example, training has to be specific in nature and meet the needs of local women, and not take a one-size-fits-all approach which generalises that all women have similar needs.

The next gender-related documents are PNG's gender policies: The National Policy for Women and Gender Equality and the GESI Policy. However, there are still issues around ownership of these policies as they trickle down to subnational level, especially in Oro province. The National Policy for Women and Gender 2011-15 is a policy that is managed by the Department of Community Development. Through the decentralisation process, this policy is supposed to be implemented by the Division of Community Development under the guidance of OPA. However, the lack of funding and resources makes implementation very difficult. This has been an ongoing issue for many years and it is difficult to distinguish who should take full responsibility to improve the situation. Given 
the Division of Community Development is part of OPA, it could be seen as OPA's direct responsibility. However, the Department of Community Development, in consultation with OPA, should clearly define who is responsible at the provincial level. Other stakeholders such as development partners and NGOs can only play a supporting role in respect to contributing to implementing the policy.

The GESI policy is managed by DPM and targets public servants at the national and subnational level. The issue around ownership of this policy at subnational level (Oro province) is with regards to who takes primary responsibility. Again, would it be the Division of Community Development given their mandate deals with gender and women's empowerment issues? Or would it be the Office of the Provincial Administrator? Reflecting on the pilot phase of the GESI policy that was conducted in West New Britain (WNB) province in 2013, it was noted that the policy was managed by the Provincial Administrator's Office (Department of Personnel Management, 2013). DPM took ownership of this policy to distinguish public servants' gender and social inclusion issues from that of the public, as that responsibility was already with the Department of Community Development and addressed by the National Gender Policy for Women Gender.

During the pilot phase, DPM and DFAT also had a hands-on role in supporting the establishment of the GESI team within the Provincial Administrator's Office. This could have contributed to the decision to have the GESI unit established under the Provincial Administrator's Office. With the arrangement in Oro province, DPM can use the pilot phase's recommendations and lessons learnt in WNB, as bases to decide where the policy should sit. However, it is also important that DPM assesses the situation in OPA critically, before deciding which division is best placed to take on such 'added' responsibility, and still produce the expected results the policy endeavours to do.

Overall, the issue of ownership of these strategies and policies is important and must be addressed at DFAT level and within the PNG government agencies, both nationally and sub-nationally. Especially given that DFAT's Gender Equality and Women's Empowerment Strategy has only recently been used in PNG, all relevant stakeholders, programme staff and beneficiaries need to have a sense of awareness and ownership of this strategy. Also, with the PNG government gender policies, the decentralisation process at the subnational level needs to take place, in order for ownership of these policies at subnational level to occur. For example, the Community Development Branch of OPA is still unclear of the National Policy for Women and Gender 2011-15. Who takes 
on the ownership of ensuring this policy is implemented in the province - OPA or the Department of Community Development at national level? Reflecting on my research question on the kind of support given by the donor and PNG government to women's empowerment in Oro province, this support has to be channelled in a way that it reaches women at the local level. From the findings of this study, it was evident that not all donor and government support for gender and women's empowerment reaches local women at the community level. This is a huge struggle for local women who have been disempowered for many years, but still long for some kind of help to improve their lives. This is an opportunity for DFAT and the PNG government agencies to capitalise on. In addition, looking at ownership in terms of the Paris Declaration, it emphasises the need for partner countries to exercise effective leadership over their development policies and strategies, and donors to commit to respecting partner countries' leadership and strengthening their capacity (OECD, 2005). For example, DFAT as the donor will endeavour to support PNG government's gender policies so the PNG government takes ownership of its policies, and be responsible for its implementation and effective delivery of gender outcomes. However, DFAT can only play a supporting role in this context.

\subsection{Communication}

Communication is another key theme that emerged from my research. As I navigated through DFAT's Gender Equality and Women's Empowerment Strategy and PNG government's gender policies, it became evident that communication is an issue. Communication needs to occur in a systematic way, at all levels, to ensure information is reaching those at the subnational level, especially those within the system of government that these strategies/policies are expected to reach.

It is important that DFAT's Gender Equality and Women's Empowerment Strategy is communicated well in PNG, through the different levels within the DFAT programmes, and the gender team at the Australian High Commission in Port Moresby. DFAT's Gender Equality and Women's Empowerment Strategy endeavours to bring gender and women's empowerment into focus with specific objectives and approaches. However, as an international document, those at management level have to decide how this strategy will translate into streams of work for all DFAT programmes in PNG. Once this decision is clear, it must be communicated well to all programmes. For example, there are three approaches to the strategy: enhancing women's voice in decision-making, leadership and peace-building; promoting economic empowerment; and ending violence against women

Camilla Ethel Angoro - Master's Thesis - Victoria University of Wellington 
(DFAT, 2016). There are number of approaches that this strategy uses and it must be clear how it would work in the PNG context. Would a PNG version of this document be useful, given PNG's unique challenges around gender and women's empowerment? Also, the strategy calls for all programmes to be gender inclusive regardless of objectives, but how practical would this arrangement be in PNG? An implementation strategy/framework for DFAT's Gender Equality and Women's Empowerment Strategy could help navigate through practical ways to implement this strategy and produce the outcomes it endeavours to. Once clarity is reached on how to practically implement this strategy in PNG, it is important to communicate this throughout all DFAT programmes.

The PNG gender-related policies also need to be communicated well from the national level to subnational level. From the findings, issues were raised about key policies not being clearly understood at the provincial level. Participants highlighted that they were not properly oriented on the use of these policies and its usefulness in the province. Policies were not budgeted for causing impediments to their implementation, furthermore causing policies to become ineffective. For example, the National Policy for Women and Gender 2011-15 has since expired, but very little could be shown as evidence of its implementation in Oro province. A view expressed by one participant was that government policies these days are merely words on paper; nothing much comes out of them as there is no budget and human resources to implement them at the subnational level. In addition, staff at the provincial level expressed the disconnect between the national office and the provincial office regarding key information not being communicated well.

Overall, communication is important for the successful implementation of key gender policies of the PNG government as well as DFAT's Gender Equality and Women's Empowerment Strategy in PNG. This is because vital information needs to be channelled to all respective groups that are responsible for implementing these policy documents. The implication of lack of communication is that it could result in the disconnect between gender policies and actual practice in implementation. This is the case for most gender policies in PNG, especially in respect of their implementation. According to Lamprell and Braithwaite (2017), gender and gender mainstreaming in PNG lack adequate prominence in policy documentation to act as a platform for change. Their recommendations indicated that gender be re-conceptualised in a way specific to the PNG 
context with emphasis placed on civil society groups who have the capacity, will and desire to affect the lives of men and women in PNG.

\subsection{Working in Collaboration and through Partnerships}

Sometimes, the lack of resources and limited funding affects PNG government's ability to implement policies over time. Therefore, during planning and development of these policies and annual work plans, it is important to look at other avenues of support such as through collaboration and working in partnerships with other stakeholders and partners. One such partner could be DFAT. Especially in light of gender work in PNG, DFAT is one of the biggest bilateral donors that supports gender and women's empowerment efforts in PNG.

As a donor in PNG, DFAT works closely with key government agencies, provincial administrations and other stakeholders that are associated with its programmes. DFAT's Gender Equality and Women's Empowerment Strategy will take effect in PNG when it works in collaboration with these agencies. It would be difficult to measure the effectiveness of the strategy if it does not work together with the recipient government in support of their gender efforts in PNG. Reflecting on the Paris Declaration on the notion of ownership, it emphasises the need for donors to commit and respect partner countries' leadership and help strengthen their capacity (OECD, 2005). DFAT can capitalise on their position as the donor to help the PNG government in its effort to implement gender initiatives. However, an international document such as DFAT's Gender Equality and Women's Empowerment Strategy, should not push the donor to drive their agenda, but work together with the recipient government to support their efforts as well.

With DFAT's strategy being implemented in PNG, there is a need for more collaboration between all DFAT programmes. With the strategy emphasising 80 per cent gender focus regardless of the objective of the programme, programmes can use this to maximise their inputs. For example, if a number of programmes are being implemented in the same locality, it would be more strategic that they work together to support gender equality and women's empowerment initiatives. For example; the KI and the JSS4D programmes in Kokoda District of Oro province could potentially use their networks and resources to increase coverage and produce quality interventions around gender equality and women's empowerment. 
Gender equality and women's empowerment in PNG have only recently obtained some attention and traction from the government. However, resources and funding still remain a huge impediment for government agencies to fully implement their policies. By working in partnership, DFAT has been able to assist the development and pilot phase of the GESI Policy. It also supported the development of another gender policy called the PNG National Strategy to Prevent and Respond to Gender Based Violence 2016-2025. However, donors can only assist where policies are in place and current. Both the GESI and National Policy for Women and Gender are outdated and need to be updated to reflect the current context of gender and women's empowerment in PNG. As highlighted by Holvoet and Inberg (2012), national policies and programmes must be put in place to stimulate equality and empowerment before donor interventions can contribute to effective implementation. In this context, donors can only play a supporting role through collaboration; they cannot be implementing recipient government's gender initiatives, but can only support where possible. The Paris Declaration on alignment emphasises the need for donors to base their support on a recipient country's strategies and policies (OECD, 2005). Therefore, DFAT's support can be aligned to the current PNG government policies on gender, for example.

At the subnational level, OPA's Division of Community Development uses collaboration as a strategy for implementing activities at the district and LLG levels. Where funding is a major constraint, the Division of Community Development relies heavily on its partners, whether donors, churches or NGOs, to support its work in the delivery of services to its rural communities. IOM, an international organisation, has helped the Division of Community Development and the Disaster Office in OPA to provide communities with community-based disaster risk reduction management which provided support to fourteen (14) rural communities in Oro province.

Overall, it is important that both the PNG government and DFAT use these collaborations and partnerships effectively to support gender equality and women's empowerment initiatives. DFAT, being the donor, can use its strategy to justify the kind of support it gives for gender equality and women's empowerment, and the PNG government can use its gender policies to seek funding and technical expertise towards the implementation of these policies and their efforts in addressing gender inequality. 


\subsection{Empowerment}

The notion of women's empowerment is often contested; therefore, it is important to understand that it can carry different meanings and ambiguity sometimes. According to Bishop and Bowman (2014), empowerment can be a challenging and inspiring concept and programmes must be mindful and design practical ways to address this issue. Reflecting on the context of local women in PNG, it is important that local women define women's empowerment according to their needs and aspirations. In designing any intervention that endeavours to contribute to women's empowerment, it must be tailored to the needs of these women in their communities. The issue of training and the use of women's organisations seem to be particularly important.

From the findings, participants indicated that training sessions designed to address women's empowerment should be targeted. However, the generalisation that all women need help could be misleading. Each woman is a unique individual, and has different needs given their situation and background. While a few participants indicated the positive outcome of training sessions undertaken, this was because it was a specific training targeted to improve their skills in their job. However, most felt the typical timing of a week was not ample to grasp key information and concepts given their ranging education and knowledge background. Thus, it is important that before any training is conducted, a training needs assessment must be carried out for OPA staff to get a sense of their level of knowledge and understanding of the concepts/knowledge being introduced to the public service. After the initial training, a follow-up session is necessary to assess the change in knowledge and skill, and to see if the next level of training should be tailored to build on their existing knowledge. For example, the JSS4D programme conducts training for parolees, probationers and ex-prisoners on starting their own business. This has improved the knowledge of these participants. The programme has also tailored a follow-up training package which includes financial management support to help those participants who have successfully started their business, but need management skills to carry their business to the next level. A few of these participants have been women, which is positive as they can be the role models for other women to follow; especially given their previous background, and that they are making an effort to change their lives for the better.

Women's organisations in PNG have been very important in supporting women's empowerment at community level. However, women who are not affiliated with such 
groups tend to miss out on opportunities. Church and community groups have played a vital role for women in communities. Groups such as the Bougainville Women's Federation and Kuk Women for Peace are examples of women's organisations that are contributing to women's empowerment at the local level (Garap, 2004). The National Policy for Women and Gender states the NCW is one of its implementing partners, and therefore it should be resourced well to carry out its mandate. This organisation has the potential to reach out to all women in PNG, especially those in rural areas. With the Provincial Council of Women branch being revitalised recently in Oro province, this organisation has the capacity to reach rural women in the province. Reflecting on the Ward 10 Council of Women of Popondetta Urban LLG, this organisation is determined to support all women in its locality despite funding and resource constraints. A positive aspect of this organisation is that they (executives and members) have access to oil palm plantations, which could help greatly in the initial phase of its establishment. They have decided that due to lack of funding under NCW, they will have to jointly fund the establishment of this organisation through member contributions of an annual membership fee of PGK 10 (NZD 5), then decide if each sub-group (categorised by roads within the plantations) will further contribute on an agreed amount towards its annual planned activities. This group and other women's groups under the Provincial Council of Women can do much for Oro province in terms of women's empowerment and gender.

In addition, if funding from provincial and district level, through the District and Provincial Development Plans, is channelled to these groups, they have the potential to impact the lives of rural women in Oro province. Reflecting on the case study done by Fletcher et al. (2016) on behalf of the Pacific Women Programme in the Pacific, women's coalitions are capable of attracting support and increasing their influence on the work they do to empower women, because they stand to improve the lives of local women. However, at present there is no direct support to any women's organisation in Oro province by DFAT or the PNG government. This is an avenue that both DFAT and the PNG government can capitalise on. Rather than trying to empower women individually, especially at local level, it would be sustainable if support is given through women's groups who already have established networks in the communities to reach out to local women. 


\subsection{Summary}

This study has highlighted the key themes of implementation of gender policies/strategies, both of DFAT's and of the PNG government's; power that is embedded within the different agencies and the researcher; ownership and communication of these gender policies/strategies; working in collaboration with and through partnerships to complement gender and women's empowerment efforts of both the donor and the recipient government's; and the need for the notion of empowerment to be defined by local women. Overall, the study showed that these key areas need further development to support gender equality and women's empowerment at subnational level, especially in Oro province. It must also be noted that there is traction and drive to support women's empowerment from DFAT and the PNG government, which is a positive indication, but more 'action' is needed than just plans and aspirations for the future. In addition, having the support of OPA and the Division of Community Development to take a more proactive approach is vital for more support for gender equality and women's empowerment in rural communities of Oro province. However, this can only happen if OPA and the Division of Community Development are adequately funded and resourced by the national government as well as the provincial government to carry out their mandated tasks. 


\section{Chapter Seven: Conclusion}

\subsection{Summary of Thesis}

This research was conducted to understand the contributions of DFAT's Gender Equality and Women's Empowerment Strategy to women's empowerment in Oro province. Without exclusively looking at donor support, this study also looked at the recipient government's support to Oro province as well. The purpose of this study was to get a sense of the development aid support to Oro province, and how much of that support trickled down to local women. This study used a qualitative approach that entailed interviews with research participants and document reviews.

\subsection{Key Themes and Findings}

The major findings from the study indicate that there is no direct support by way of funding or resourcing to local women's groups in Oro province by DFAT or the PNG government. There were issues with implementation and ownership of gender policies/strategies for both DFAT and the PNG government in Oro province. In the absence of resources and funding from government for women's empowerment efforts, OPA's Division of Community Development is working well in collaboration with other stakeholders within the province to implement gender equality and women's empowerment initiatives. Women's organisations proved to be an avenue to support women's empowerment at community level; with the notion of empowerment to be determined by local women in order for them to truly embrace empowerment within their context. There is potential for further research to be informed by this study. Relevant areas include: focusing on the political support that emanates from local politicians within their term in Parliament; and Oro Provincial Government support for women's empowerment through the funding and resourcing of the Provincial and District Development Plans.

\subsection{Implications of Study}

The implications of the findings of my study are focused around theory, research and practice. My theoretical framework was informed by post-structuralist feminist theory, GAD and the women's empowerment framework. All findings were consistent within the attributes of these frameworks, especially around the notions of power, empowerment 
and gender relations. (See Table 1, Chapter 4 for details of these attributes.) The methodology proved appropriate. Grounded theory and constructivism helped with understanding women's lived realities and how they create their own meanings in this study. However, issues may exist around measurement of the notion of empowerment and what that entails in a local context. This study has found empowerment to be contested and complex to understand. Another potential approach is to critically assess what empowerment entails and its measurement within these key participant groups (DFAT, PNG government, and local women). This omission may guide future researchers.

This study has potential benefit for a number of agencies. These include: the PNG government, as it needs this information for the updating of its GESI Policy and National Policy for Women and Gender; DFAT, as there is a need to have an implementation strategy for its Gender Equality and Women's Empowerment Strategy in PNG; the Oro Provincial Administration, in examining the way they support the Division of Community Development to address gender and women's issues and the implementation of GESI Policy; the Oro Provincial Government, Sohe and Ijivitari District Administrations, as they need to reflect on and include gender equality and women's empowerment initiatives in their budgets and plans for the sustainability of local women's organisations; and the Oro Provincial Council of Women, as they need quality information to reach out to potential partners to support their work in communities. All these organisations could benefit from the findings of this study as the information might improve the way they are currently supporting gender equality and women's empowerment efforts in PNG, especially in Oro province.

\subsection{Evaluation of Study}

It must be noted that this study has limitations. There are number of issues that contribute to the limitations of this research. Firstly, the timing of the fieldwork was conducted during PNG's national election which meant that some key participants could not participate in my research, particularly the three Members of the National Parliament (2012-2017) from Oro province. This was a lost opportunity to broaden those consulted. It would have been beneficial to include the political view of leaders regarding the support they give towards gender and women's empowerment during their term in National Parliament - especially given that the now former Sohe MP was female and the Minister for Community Development during her term in Parliament. Also, it would have been 
beneficial to include women's groups based in the rural areas to give more insight and diversity in terms of the issues they face, and of their aspirations and hopes for the future. In addition, seeking views of communities who are direct programme beneficiaries of DFAT programmes in Oro province could be a way to assess the direct trickle-down effect of DFAT's support to Oro province.

There is potential for future research around the topic of international aid and recipient government's support to women's empowerment in PNG. Firstly, research might look at local politicians' contributions in implementing women's empowerment initiates in Oro province. This area was initially included as part of my research but could not be investigated due to the unavailability of three local politicians involved in the 2017 National General Elections. Another area worth investigating is how DFAT's funding through its Gender Equality and Women's Empowerment Strategy 2016 moves through the different political and bureaucratic arrangements at national level and in Oro province. A question regarding this was initially proposed in my research proposal in 2016, but due to its scope, technicality and sensitivity, I was advised it could be a potential $\mathrm{PhD}$ topic not a Master's level one. Lastly, I feel investigating the notion of 'empowerment' in Oro province, and in my district of Sohe, with remote communities from Ioma LLG, would help bring their issues around gender equality and women's empowerment to light and support efforts to fund and allocate resources to meet their specified needs. For a long time, the villages/communities of Ioma LLG have been forgotten by the government and have lacked basic services due to its remoteness to the main township of Popondetta.

\subsection{Final Remarks}

The study found that DFAT's Gender Equality and Women's Empowerment Strategy and its associated funding have much potential to improve women's lives in PNG. However, it also found that much of this potential is not being realised due to structural constraints and attitudinal issues, and problems of implementation. Nevertheless, it is vital that the concern for, and attention to, women's empowerment remains and is strengthened. There is also the opportunity for further research that this study highlights through the gaps identified, which could add more value to development work in the areas of gender, women's empowerment and the nature of support from international development agencies in PNG and the Pacific. 


\section{References}

Adams, P. (2006). Exploring social constructivism: Theories and practicalities. Education 3-13, 34(3), 243-257.

Aiafi, P. (2017). The nature of public policy processes in the Pacific Islands. Asian and the Pacific Policy Studies, 4(3), 451-466. doi:10.1002/app5.196

Anderson, J. (2015). Struggling with 'this gender relations thing' in the Papua New Guinea Church Partnership Program. Gender, Place \& Culture, 22(10), 1357-1373. doi:10.1080/0966369X.2014.9701333

Appleford, G. (2000). Women's groups for whom? The colonisation of women's groups in Papua New Guinea. Development Practice 10(1), 82-89.

Australian Agency for International Development (AusAID). (1997). Policy Statement on Gender and Development: Australia's Aid Commitment. Canberra, Australia. Author.

Australian High Commission. (2016). A new hub for empowerment in Bougainville. Retrieved from http://png.embassy.gov.au/pmsb/592.html

Baker, K. (2014). Explaining the outcome of the gender quota campaigns in Samoa and Papua New Guinea. Political Science, 66 (1), 63-83. doi:10.1177/0032318714531428

Batliwala, S. (1994). Empowerment of women in South Asia: Concepts and practices. New Delhi: Asian-South Pacific Bureau of Adult Education, and FAO's Freedom from Hunger Campaign - Action for Development.

Bhagwan-Rolls, S. (2011). Pacific regional perspectives on women and the media: Making the connection with UN Security Council Resolution 1325 (Women, Peace, and Security) and section J of the Beijing Platform for Action. Signs 36(3), 570577.

Bishop, D., \& Bowman, K. (2014). Still learning: A critical reflection on three years of measuring women's empowerment in Oxfam. Gender and Development, 22(2), 253-269. doi:10.1080/13552074.2014.920993 
Brouwer, E.C., Harris, B.M., \& Tanaka, S. (Eds.). (1998). Gender analysis in Papua New Guinea. Washington DC: World Bank.

Byrne, M. (2001). Grounded theory as a qualitative research methodology. AORN Journal, 73(6), 1155-1156.

Campbell, M., \& Teghtsoonian, K. (2010). Aid Effectiveness and women's empowerment: Practices of governance in the funding of international development. Signs: Journal of Women in Culture and Society, 36(1), 177-202. doi: $10.1086 / 652914$

Clark, L. (2014). Options for promoting increased participation of women in Parliaments and in elected bodies at subnational level in the Pacific Region 2014-2017. Suva:UNDP Pacific Centre. PacificPlus Consulting.

Clarke, M. (2015). Innovative delivery mechanism: Australian aid partnership with churches in Papua New Guinea. Journal of International Development, 27, 14621478. doi:10.1002/jid.3185

Connelly, P., Li, M., MacDonald, M., \& Parpart, J. (2000). Feminism and development: Theoretical perspectives. In J. Parpart, P. Connelly \& E. Barriteau (Eds.), Theoretical Perspectives on Gender and Development (pp. 51-160). Ottawa: International Development Research Centre.

Cornwall, A., \& Rivas, A. (2015). From gender equality and women's empowerment to global justice: Reclaiming a transformative agenda for gender and development. Third World Quarterly, 36(2), 396-415. doi:10.1080/01436597.2015.1013341

Creswell, J. (Ed.). (2009). Research design: Qualitative, quantitative and mixed methods approaches ( $3^{\text {rd }}$ ed.). Los Angeles: SAGE.

Davies, B., \& Gannon, S. (2011). Feminism / post structuralism. In B. Somekh \& C. Lewin (Eds.), Theory and methods in social research (pp. 312-319). London: SAGE Publications.

Department of Foreign Affairs and Trade. (2015). Australian Aid Investment Plan for PNG 2015-2016 to 2017-2018. Canberra, Australia: Author. 
Department of Foreign Affairs and Trade. (2015). Justice Services and Stability for Development Programme Design Document. Port Moresby: Author.

Department of Foreign Affairs and Trade. (2015). PNG Governance Facility Design Document. Port Moresby: Author.

Department of Foreign Affairs and Trade. (2015). Report on Aid Program Performance in PNG: For the year 2015-2016. Canberra, Australia: Author.

Department of Foreign Affairs and Trade. (2016). DFAT Gender Equality and Women's Empowerment Strategy 2016. Canberra, Australia: Author.

Department of Foreign Affairs and Trade. (2017). Transport Sector Services Programme: Oro Bridges Reconstruction Project Report. Port Moresby: Author.

Dickson-Waiko, A. (2003). The Missing rib: Mobilising church women for change in Papua New Guinea. Oceania 74 1(2), 98-119.

Douglas, B. (2003). Christianity, tradition, and everyday modernity: Towards an anatomy of women's groups in Melanesia. Ocean 74 1(2), 6-23.

England, K. (1994). Getting personal: Reflexivity, positionality, and feminist research. Professional Geographer 46(1), 80-89.

English, L. (2012). Poststructuralist feminism. In A. Mills, G. Durepos \& E. Wiebe (Eds.), Encyclopaedia of case study research (pp. 711-713). doi:10.4135/9781412957397.n262

Eyben, R. (2008). Conceptualising policy practices in researching pathways of women's empowerment. Pathways working paper. Pathways of Empowerment, University of Sussex. Brighton: DFID.

Fletcher, G., Brimacombe, T., \& Roche, C. (2016). Power, politics and coalitions in the Pacific: Lessons from collective action on gender and power (Research Paper). Suva/Birmingham: Pacific Women/Developmental Leadership Program, University of Birmingham. 
Fryatt, R., Mills, A., \& Nordstrom, A. (2010). Financing of health systems to achieve the Millennium Development Goals in low-income countries. The Lancet, 375, 419426.

Garap, S. (2004). Kup Women for peace: Women taking action to build peace and influence community decision-making. State, Society and Governance in Melanesia Discussion Paper 2004/4. Canberra: Australia National University.

Grown, C., Addison, T., \& Tarp, F. (2016). Aid for gender equality and development: Lessons and challenges. Journal of International Development, 28(0), 311-319. doi:10.1002/jid

Hako Women's Collective. (2016). Opening of BWF new building. Retrieved from http://hakowomen.blogspot.co.nz/p/bougainville-womens-federation.html

Hako Women's Collective. (2017). About BWF. Retrieved from http://hakowomen.blogspot.co.nz/p/bougainville-womens-federation.html

Hawksley, C. (2009). Australia's aid diplomacy and the Pacific Islands: Change and continuity in middle power foreign policy, Global Change, Peace and Security, 21(1), 115-130. doi:10.1080/14781150802659473

Health volunteers open new accounts. (2016, September 28). Post Courier, p. 20.

Hennik, M., Hutter, I., \& Bailey, A. (2011). Qualitative research methods. London: SAGE Publications.

Hilton, R., \& Earnest, J. (2010). Stressors, coping, and social support among women in Papua New Guinea. Qualitative Health Research 20(2), 224-238.

Holvoet, N. (2010). New aid modalities through a gender lens: Is love really in the air? European Journal of Development Research, 22(1), 97-117.

Holvoet, N., \& Inberg, L. (2012). Changing aid policies through a gender lens: An international perspective and the case of Dutch development cooperation. Journal of International Woman's Studies, 13(3), 1-16. 
House, W.J. (2000). ICPD goals and the thresholds: How well have the Pacific Island countries performed? Development Bulletin 51(0), 61-65.

Howes, S., Ilave, D., Plana, D., \& Femli PNG. (2017). Responding to gender based violence in an urban setting: The early story of Femli PNG. In P. Thomas \& M. Keen (Eds.), Urban Development in the Pacific 78 (pp. 67-78). Canberra: Australia National University.

Hunt, J. (1996). Gender awareness in the Australian aid program. In P. Kilby (Ed.), Australia's aid program: Mixed messages and conflicting agendas (pp. 65-78). Melbourne: Monash Asia Institute and Community Aid Abroad.

Jolly, M. (2000). Woman ikat raet long human raet o no? [Do women have the right to human rights?] In A. Hilson, M. Macintyre, V. Mackie \& M. Stevens (Eds.), Human rights and gender politics (pp. 124-146). New York: Routledge.

Julien, H. (2012). Content analysis. In L.M. Given (Ed.), The SAGE encyclopedia of qualitative research methods (pp. 121-122). doi: 10.4135/9781412963909

Kabeer, N. (1999). Resources, agency, achievements: Reflections on the measurement of women's empowerment. Development and Change, 30(3), 435-464.

Kabeer, N. (2005). Gender equality and women's empowerment: A critical analysis of the third millennium development goal 1. Gender and Development, 13(1), 13-24.

Kara, H. (2017). Research and evaluation for busy students and practitioners. doi:130.195.253.42

Lamprell, G., \& Braithwaite, J. (2017). Mainstreaming gender and promoting intersectionality in Papua New Guinea's health policy: A triangulated analysis applying data-mining and context analytic techniques. International Journal for Equity in Health 16(65), 1-10.

Lewis, N.D. (1998). Intellectual intersections: Gender and health in the Pacific. Social Science and Medicine, 46(6), 641-659. 
McKinnon, K., Carnegie, M., Gibson, K., \& Rowland, C. (2016). Gender equality and economic empowerment in the Solomon Islands and Fiji: A place-based approach. Gender, Place \& Culture, 23(10), 1376-1391.

Merriam, S., Johnson-Bailey, J., Lee, M., Kee, Y., Ntseane, G., \& Muhamad, M. (2001). Power and positionality: Negotiating insider/outsider status within and across cultures. International Journal of Lifelong Education, 20(5), 405-416. doi:10.1080/026011370120490

Molyneux, M., \& Razavi, S. (2005). Beijing plus ten: An ambivalent record on gender justice. Development and Change, 36(6), 984-1010.

Mosedale, S. (2005). Assessing women's empowerment: Towards a conceptual framework. Journal of International development, 17, 243-257. doi:10.1002/jid.1212

Moser, C. (1993). Gender planning and development: Theory, practice and training. London: Routledge.

Narayan, U. (1998). Essence of culture and a sense of history: A feminist critique of cultural essentialism. Hypatia, 13(2), 86-106.

Nazneen, S., \& Sultan, M. (2014). Positionality and transformative knowledge in conducting feminist research on empowerment in Bangladesh. Women's Studies International Forum 45, 63-71.

Nussbaum, M.C. (1995). Human capabilities, female human beings. In M.C. Nussbaum \& J. Glover (Eds.), Women, culture and development (pp. 61-104). Oxford: Clarence Press.

Okin, S.M. (1998). Feminism, women's human rights, and cultural differences. Hypathia, 13(2), 32-52.

Panda, S.M. (2000). Women's empowerment through NGO interventions: A framework for assessment. Social Change, 3(3\&4), 44-63.

Papua New Guinea Department of Community Development. (2011). National Policy for Women and Gender 2011-2015. Port Moresby, Papua New Guinea: Author. 
Papua New Guinea Department of Community Development. (2011). PNG Country Gender Assessment. Port Moresby, Papua New Guinea: Author.

Papua New Guinea Department of Community Development. (2016). Papua New Guinea National Strategy to Prevent and Respond to Gender Based Violence 2016-2025. Port Moresby, Papua New Guinea: Author.

Papua New Guinea Department of National Planning and Monitoring. (2015). Millennium Development Goals Final Summary Report 2015. Port Moresby, Papua New Guinea: Author.

Papua New Guinea Department of National Planning and Monitoring. (2015). Development Cooperation Policy 2015. Port Moresby, Papua New Guinea: Author.

Papua New Guinea Department of National Planning and Monitoring. (2007). PNG Vision 2050. Port Moresby, Papua New Guinea: National Strategic Plan Taskforce.

Papua New Guinea Department of National Planning and Monitoring. (2010). PNG Development Strategic Plan 2010-2030. Port Moresby, Papua New Guinea: Author.

Papua New Guinea Department of National Planning and Monitoring. (2011). PNG Medium Term Development Plan 2011-2015. Port Moresby, Papua New Guinea: Author.

Papua New Guinea Department of National Planning and Monitoring. (2015). PNG Medium Term Development Plan 2 2016-2017. Port Moresby, Papua New Guinea: Author.

Papua New Guinea Department of Personnel Management. (2013). Gender Equity and Social Inclusion Policy 2013-2015. Port Moresby, Papua New Guinea: Author.

Papua New Guinea Department of Treasury. (2016). Mid-Year Economic Fiscal Outlook Report 2016. Port Moresby, Papua New Guinea: Author.

Papua New Guinea National Statistics Office. (2011). National Population and Housing Census 2011. Port Moresby, Papua New Guinea: Author. 
Papua New Guinea Office of Climate Change and Development. (2014). National Climate Compatible Development Management Policy 2014. Port Moresby, Papua New Guinea: Author.

Parpart, J., \& Marchand, M. (1995). Exploding the cannon: An introduction/conclusion. In M. Marchand \& J. Parpart (Eds.), Feminism, post modernism and development (pp. 1-25). London: Routledge.

Pearson, R., \& Tomalin, E. (2008). Intelligent design? A gender-sensitive interrogation of religion and development. In G. Clarke \& M. Jennings (Eds.), Development, civil society and faith-based organisations: Bridging the Sacred and the Secular (pp. 4672). Basingstoke: Palgrave MacMillan.

Peet, R., \& Hartwick, E. (Eds.) (2009). Theories of development: Contentions, arguments, alternatives ( $2^{\text {nd }}$ ed.). New York: Guilford Press.

Rathgeber, E. M. (1995). Gender and development in action. In M. Marchand \& J. Parpart (Eds.), Feminism, post modernism and development (pp. 204-220). London, England: Routledge.

Ravunamu, A., Gore, B., Koralyo, R.P. (2015). Sorcery and witchcraft-related killings in Papua New Guinea: The criminal justice system response. In M. Forsyth \& R. Eves (Eds.), Responses to Sorcery and Witchcraft Beliefs and Practices in Melanesia (pp. 241-253). Canberra: ANU Press.

Razavi, S., \& Miller, C. (1995). From WID to GAD: Conceptual shifts in the women and development discourse. UNRISD Occasional Paper Series OBP 1. Geneva: UNRISD.

Riddle, R. (2007). Does foreign aid really work? New York: Oxford University Press.

Rowlands, J. (1998). A word of the times, but what does it mean? Empowerment in the discourse and practice of development. In. H. Afshar (Ed.), Women and empowerment: illustrations for the third world (pp. 11-34). London: Macmillan.

Schech, S. (1998). Between tradition and post-coloniality: The location of gender in Australian development policy. Australian Geographer, 29(3), 389-404. doi: $10.1080 / 00049189808703231$ 
Schech, S., \& McNally, S. (2001). Interpreting gender policy: The challenges of negotiating difference in Australian development projects in Vietnam. Canadian Journal of Development Studies, 22(3), 655-674. doi:10.1080/02255189.2001.9668838

Sharp, J., Briggs, J., Yacoub, H., \& Hamed, H. (2003). Doing gender and development: Understanding empowerment and local gender relations. Transaction of the Institute of British Geographies, 28(3), 281-295.

Sheerattan-Bisnauth, P., \& Peacock, P. (Eds.). 2010. Created in God's image: From hegemony to partnership. A church manual on men as partners: promoting positive masculinities. Geneva: World Communion of Reformed Churches, World Council of Churches.

Sohe District Administration. (2012). Sohe District Plan 2012-2017. Popondetta, Papua New Guinea: Author.

Sohe District, Papua New Guinea. (2015). Map of Oro Province including Sohe and Ijivitari districts. Retrieved on December 2017 from http://sohedistrictpr.blogspot.co.nz/2015/10/orokaivas-of-popondetta.html

Spark, C. (2010). Changing Lives: Understanding the barriers that confront educated women in Papua New Guinea. Australia Feminist Studies, 25(63), 17-30.

Spark, C., \& Corbett, J. (2016). Emerging women leaders' views on political participation in Melanesia. International Feminist Journal of Politics, 1-15. doi:10.1080/14616742.2016.1189680

Summer Institute of Linguistics, Papua New Guinea. (2007). Map of Papua New Guinea. Retrieved on December 2017 from http://www01.sil.org/pacific/png/show_maps.asp

Transparency International. (2018). Surveys on Corruption Index 2017. Retrieved from https://www.transparency.org/news/feature/corruption_perceptions_index_2017\#t $\underline{\text { able }}$

United Nation Development Programme. (2016). Human development report 2016: Briefing note for countries on the 2016 human development report - Papua New Guinea. New York: Author. 
United Nations (1995). Beijing Declaration and Platform for Action. New York: Author.

United Nations (2009). Harmful practices against women in Pacific Island Countries: Customary and conventional laws. Suva: Imrana Jalal

United Nations (2010). Millennium development goals: Second national progress report for Papua New Guinea. Port Moresby: Author.

Urquhart, C. (2013). Grounded theory for qualitative research: A practical guide. London: SAGE Publications.

Van Reisen, M., \& Ussar, M. (2005). Accountability upside down: Gender qquality in a partnership for poverty eradication. Brussels: Eurostep \& Social Watch.

Varga-Dobai, K. (2012). The relationship of researcher and participant in qualitative inquiry: From 'self and other' binaries to the poststructuralist feminist perspective of subjectivity. The Qualitative Report 17(93), 1-17. Retrieved from http://www.nova.edu/ssss/QE/QR17/varga-dobai.pdf

Whitehead, A. (2002). Failing women, sustaining poverty: Gender in poverty reduction strategy papers. Report for the UK Gender and Development Network.

World Bank. (2011). What is empowerment? Overview. Retrieved from http://web.worldbank.org/WBSITE/EXTERNAL/TOPICS/EXTPOVERTY/EXT EMPOWERMENT/0,,contentMDK:20272299 menuPK:486417 pagePK:148956 piPK:216618 theSitePK:486411,00.html

World Bank. (2017). Overview of the World Bank in Papua New Guinea. Retrieved from http://www.worldbank.org/en/country/png/overview

Yawi, E. J. (2012). Exploring the experiences of female students' educational transition from secondary to tertiary education. A study in a university in Papua New Guinea (Master's thesis, University of Waikato, Hamilton, New Zealand). Retrieved from https://hdl.handle.net/10289/6643

Zukerman, E., \& Garrett, A. (2003). Do poverty reduction papers address gender? A gender audit of 2002 PRSPs. Washington, D.C: Gender Action 


\section{Appendices}

\section{Ethics Approval from VUW Human Ethics Committee}

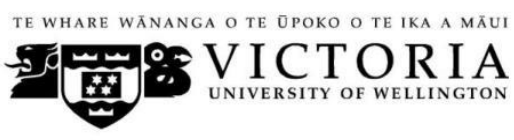

MEMORANDUM

$$
\begin{aligned}
& \text { Phone } \\
& \text { Email }
\end{aligned}
$$

\begin{tabular}{l|l}
\hline TO & Camilla Angoro \\
\hline COPY TO & John Overton \\
\hline FROM & AProf Susan Corbett, Convener, Human Ethics Committee \\
\hline \multicolumn{2}{|l}{12 May 2017} \\
\hline PATE & 1 \\
\hline SUBJECT & $\begin{array}{l}\text { Ethics Approval: 24463 } \\
\text { The decentralization of Australian Aid's gender equality and } \\
\text { women's empowerment strategy in Oro Province, Papua New } \\
\text { Guinea }\end{array}$ \\
\hline
\end{tabular}

Thank you for your application for ethical approval, which has now been considered by the Standing Committee of the Human Ethics Committee.

Your application has been approved from the above date and this approval continues until 5 March 2018. If your data collection is not completed by this date you should apply to the Human Ethics Committee for an extension to this approval.

Best wishes with the research.

Kind regards

Susan Corbett

Convener, Victoria University Human Ethics Committee 


\title{
2. Supporting Letter from Supervisor for Research Fieldwork in PNG
}

\author{
Victoria \\ UNIVERSITY OF WELLINGTON \\ te Qpoko ofe lka a Mău

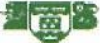

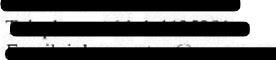

2 May 2017

To Whom it May Concern

Re: Camilla Angoro

I am writing in support of Camilla Angoro's application to undertake overseas fieldwork in Papua New Guinea in May-July 2017. I am supervising Camilla along with Dr Luke Kiddle.

Camilla has worked steadily and is very well organised and well prepared for her fieldwork. She has completed her research proposal to a high standard and her ethics application is in the final stages of approval. She is also going through our School's health and safety procedures for field research. She is well on, or ahead, of schedule at this stage for completion of her thesis.

Her topic for her Development Studies thesis requires her to complete interviews and observation in Papua New Guinea. The thesis examines how aid has contributed to women's empowerment in Oro Province. Being from this region, Camilla is well prepared and we look forward to a very interesting piece of research.

Yours Sincerely,

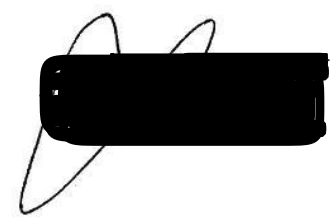

(Prof. John Overton) 


\section{Letter seeking approval from DPM to conduct research with organisation}

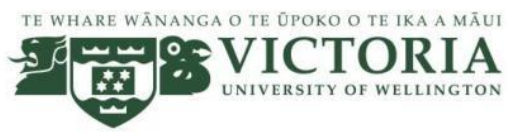

07th June, 2017

Camilla Angoro

Victoria U niversity of Wellington,

P.0 Box 600 ,

Wellington.

New Zealand

John M. Kali, CMG OBE

Secretary

Department of Personnel Management

P.0 Box 519,

Waigani.

National Capital District

Papua New Guinea

My dear Secretary,

Subject: Seeking_Permission to Conduct Research with GESL Team - Department of Personnel Management

My name is Camilla Angoro, and I am a Papua New Guinean post-graduate student from the School of Geography, Environment and Earth Sciences at Victoria University of Wellington, in New Zealand.

I am currently doing a small research towards partial fulfilment of my Master's Degree in Development Studies. My research looks at the Decentralisation of Australian Aid's Gender Equality and Women's Empowerment Strategy in Papua New Guinea. However, without limiting my scope of study to only Australian Aid funded gender projects in Oro Province and Papua New Guinea, I wish to also understand the contributions of PNG Government's Gender Policies that support women's empowerment at national and sub-national levels.

As such, I wish to seek permission to interview the GESI team in your department regarding the GESI policy; its formulation, implementation, and the collaboration (if any) with Australian Aid to support the work of the policy in Papua New Guinea. Interviews with the GESI Team will only take thirty (30) minutes and a summary of my research will be made available to the department once my master's thesis has been completed. I anticipate that to be around April, 2018.

I am also attaching my information sheet, consent form and human ethics approval from the university for your reference and noting.

Should you require more information regarding my research, please do not hesitate to contact me on 


\section{Letter seeking approval from DNPM to conduct research with the organisation}

$26^{\text {th }}$ of May, 2017

Camilla Angoro

P.O Box 105,

Konedobu.

National Capital District

Ms. Hakaua Harry

Secretary

Department of National Planning \& Monitoring

P.O Box 631

Waigani.

National Capital District

Dear Secretary,

Subject: Seeking Permission to Conduct Research with the Australian Aid Branch - Department of National Planning and Monitoring

My name is Camilla Angoro, and I am a post-graduate student from the Victoria University of Wellington in New Zealand.

I'm currently doing a small research towards partial fulfilment of my Master's Degree on the topic of the Decentralisation of Australian Aid's Gender and Women's Empowerment Strategy in Oro Province, Papua New Guinea. As such, I wish to seek permission from your department to interview Ms. IIma Gani and other staff (if need be) of the Australian Aid Branch, in light of the coordination of Australian Aid in Papua New Guinea, and its movement to sub-national level. Interviews will only take 30 minutes, and if approval is given, 1 hope to conduct this interview on Thursday, $01^{\text {st }}$ of June at $10 \mathrm{am}$.

I have Human Ethics Approval from Victoria University of Wellington to conduct this research which I am attaching for your reference and noting.

If you require more information regarding my research, please do not hesitate to contact me on

Thank you and looking forward to a favourable response.

Yours faithfully,

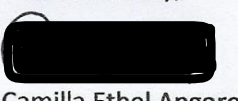

Camilla Ethel Angoro

Development Studies - Master's Thesis Student

Victoria University of Wellington 


\section{Consent form - Group 1}

\section{TE WHARE WĀNANGA O TE OPOKO O TE IKA A MÃUI Si: \\ The Decentralisation of DFAT's Gender Equality and Women's Empowerment Strategy in Oro Province, Papua New Guinea \\ CONSENT TO INTERVIEW_DFAT OFFICALS}

This consent form will be held for 3 years.

Researcher: Camilla Angoro, School of Geography, Environment and Earth Sciences, Victoria University of Wellington, New Zealand.

- I have read the Information Sheet and the project has been explained to me. My questions have been answered to my satisfaction. I understand that I can ask further questions at any time.

- I agree to take part in an audio recorded interview.

I understand that:

- I may withdraw from this study at any point before 31/08/17 without giving any reason, and any information that I have provided will be returned to me or destroyed.

- The information I have provided will be destroyed 3 years after the research is finished.

- $\quad$ Any information I provide will be kept confidential to the researcher and the supervisor. I understand that the results will be used for a Master's thesis report and a summary of the results may be used in academic reports and/or presented at conferences.

- $\quad$ I would like to receive a summary of the final report and have added my email Yes $\square \quad$ No $\square$ address below.

Signature of participant:

Name of participant:

Date:

Contact details: 


\section{Consent form - Group - 2}

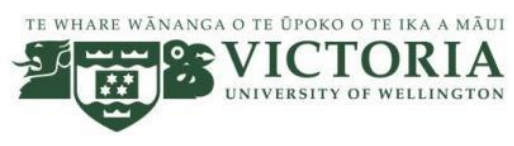

\section{The Decentralisation of Australian Aid's Gender Equality and Women's Empowerment Strategy in Oro Province, Papua New Guinea}

\section{CONSENT TO INTERVIEW_PNG GOVERNMENT OFFICIALS}

This consent form will be held for 3 years.

Researcher: Camilla Angoro, School of Geography, Environment and Earth Sciences, Victoria University of Wellington, New Zealand.

- I have read the Information Sheet and the project has been explained to me. My questions have been answered to my satisfaction. I understand that I can ask further questions at any time.

- I agree to take part in an audio recorded interview.

I understand that:

- I may withdraw from this study at any point before $31 / 08 / 17$ without giving any reason, and any information that I have provided will be returned to me or destroyed.

- $\quad$ The information I have provided will be destroyed 3 years after the research is finished.

- $\quad$ Any information I provide will be kept confidential to the researcher and the supervisor. understand that the results will be used for a Master's thesis report and a summary of the results may be used in academic reports and/or presented at conferences.

- My name will not be used in reports, nor will any information that would identify me.

- I would like a summary of my interview:

Yes $\square \quad$ No $\square$

- $\quad$ I would like to receive a summary of the final report and have added my email Yes $\square \quad$ No $\quad \square$ address below.

Signature of participant:

Name of participant:

Date:

Contact details: 


\section{Consent form - Group 3 (This group did not take part in the interview due}

to their busy schedule).

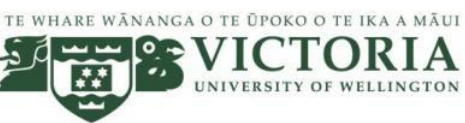

\section{The Decentralisation of Australian Aid's Gender Equality and Women's Empowerment Strategy in Oro Province, Papua New Guinea}

\section{CONSENT TO INTERVIEW_LOCAL LEADERS}

This consent form will be held for 3 years.

Researcher: Camilla Angoro, School of Geography, Environment and Earth Sciences, Victoria University of Wellington, New Zealand.

- I have read the Information Sheet and the project has been explained to me. My questions have been answered to my satisfaction. I understand that I can ask further questions at any time.

- I agree to take part in an audio recorded interview.

I understand that:

- I may withdraw from this study at any point before $31 / 07 / 17$ without giving any reason, and any information that I have provided will be returned to me or destroyed.

- The information I have provided will be destroyed 3 years after the research is finished.

- $\quad$ Any information I provide will be kept confidential to the researcher and the supervisor. understand that the results will be used for a Master's thesis report and a summary of the results may be used in academic reports and/or presented at conferences.

- I would like a summary of my interview:

- I would like to receive a summary of the final report and have added my email Ye No address below.

Signature of participant:

Name of participant:

Date:

Contact details: 


\section{Consent form - Group 4 (English Version)}

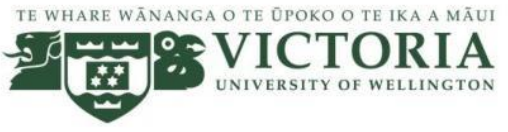

\section{The Decentralisation of Australian Aid's Gender Equality and Women's Empowerment Strategy in Oro Province, Papua New Guinea \\ CONSENT TO INTERVIEW_LOCAL WOMEN}

This consent form will be held for 3 years.

Researcher: Camilla Angoro, School of Geography Environment Earth Sciences, Victoria University of Wellington, New Zealand.

- I have read the Information Sheet and the project has been explained to me. My questions have been answered to my satisfaction. I understand that I can ask further questions at any time.

- I agree to take part in an audio recorded interview.

I understand that:

- I may withdraw from this study at any point before 31/07/17 without giving any reason, and any information that I have provided will be returned to me or destroyed.

- The information I have provided will be destroyed 3 years after the research is finished.

- Any information I provide will be kept confidential to the researcher and the supervisor. I understand that the results will be used for a Master's thesis report and a summary of the results may be used in academic reports and/or presented at conferences.

- My name will not be used in reports, nor will any information identify me.

- I would like to receive a summary presentation of final report

Signature of participant:

Name of participant:

Date:

Contact details: 


\section{Consent form - Group 4 (Tok Pisin Version)}

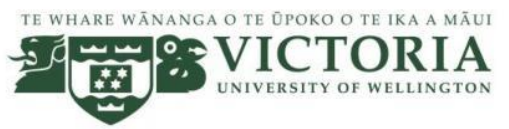

\section{The Decentralisation of Australian Aid's Gender Equality and Women's Empowerment Strategy in Oro Province, Papua New Guinea}

\section{PEPA LO GIVIM TOK ORAIT LO TOKTOK_OL MERI}

Displa tok orait bai stap inap tripla yia

Wok painum aut blo: Camilla Angoro, School of Geography, Environment and Earth Sciences, Victoria University of Wellington, New Zealand.

- Mi riddim pinis toktok lo toksave pepa na projek ibin klia lo mi. Ol narapla askim bin orait. Mi ken askim any askim lo taim lo toktok.

- Mi wanbel lo toktok taim audio recorder em on

Mi save olsem taim:

- $\quad$ Mi laik raus lo displa wok painim aut bai mi mas toksave bipo lo 31/07/17, mi no nap givim rison lo why mi raus lo displa wok painim aut. Olgeta toktok mi givim mas kam bek lo mi or bai destroim olgeta.

- $\quad$ Olgeta toktok mi givim mas destroim afta tripla yia.

- $\quad$ Olgeta toktok mi givim mas stap confidential lo yu na tisa blo yu.

- Nem blo mi stret no nap usim lo ripot blo yu, na narapla information wea bai putim mi lo ples klia.

Signature of participant:

Name of participant:

Date:

Contact details: 


\title{
10. Information sheet - Group 1
}

\author{
TE WHARE WĀNANGA O TE ÔPOKO O TE IKA A MÃUI

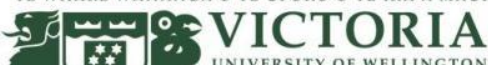 \\ \& $\because$ UNIVERSITY of Wellington

\section{The Decentralisation of DFAT's Gender Equality and Women's Empowerment Strategy in Oro Province, Papua New Guinea}

\section{INFORMATION SHEET FOR PARTICIPANTS DFAT OFFICIALS}

Thank you for your interest in this project. Please read this information before deciding whether or not to take part. If you decide to participate, thank you. If you decide not to take part, thank you for considering my request.

\section{Who am I?}

My name is Camilla Angoro and I am a Master student in Development Studies programme at Victoria University of Wellington, New Zealand. This research project is work towards my master's thesis.

\section{What is the aim of the project?}

This project aims to understand the contributions of DFAT in supporting gender and women's empowerment in Oro Province of Papua New Guinea.

This research has been approved by the Victoria University of Wellington Human Ethics Committee [approval number 24463].

\section{How can you help?}

If you agree to take part, I will interview you at a venue of your choosing. I will ask you questions about DFAT's Gender Equality and Women's Empowerment Strategy in Papua New Guinea, and more specifically, Oro Province. The interview will take approximately 30 minutes. I, Camilla, will audio record the interview. You can stop the interview at any time, without giving a reason. You can withdraw from the study by contacting me at any point before the $31^{\text {st }}$ of August, 2017. If you withdraw, the information you provided will be destroyed or returned to you.

\section{What will happen to the information you give?}

You will not be named in the final report but your organisation will be named (provided you have the authority to agree to this on behalf of the organisation).

Only my supervisors and I will read the notes or transcript of the interview. The interview transcripts, summaries and any recordings will be kept securely and destroyed 3 years after the research ends. 


\section{What will the project produce?}

The information from my research will be used in my Master's thesis report.

If you accept this invitation, what are your rights as a research participant?

You do not have to accept this invitation if you don't want to. If you do decide to participate, you have the right to:

- $\quad$ choose not to answer any question;

- $\quad$ ask for the recorder to be turned off at any time during the interview;

- $\quad$ withdraw from the study before 31/07/2017;

- $\quad$ ask any questions about the study at any time;

- $\quad$ receive a copy of your interview recording (if it is recorded);

- $\quad$ read over and comment on a written summary of your interview;

- $\quad$ agree on another name for me to use rather than your real name;

- be able to read any reports of this research by emailing the researcher to request a copy.

If you have any questions or problems, who can you contact?

If you have any questions, either now or in the future, please feel free to contact either:

\section{Student:}

Name: Camilla Angoro

University email address:

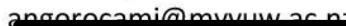

\section{Supervisor:}

Name: Professor John Overton

Role: Director, Postgraduate Programme in Development Studies

School: Geography, Environment an Earth Sciences

Phone:

E-mail:

Human Ethics Committee information

If you have any concerns about the ethical conduct of the research you may contact the Victoria University HEC Convener: Associate Professor Susan Corbett. Email 


\section{Information Sheet - Group 2}

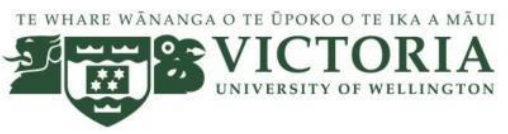

\section{The Decentralisation of Australian Aid's Gender Equality and Women's Empowerment Strategy in Oro Province, Papua New Guinea \\ INFORMATION SHEET FOR PARTICIPANTS_PNG GOVERNMENT OFFICIALS}

Thank you for your interest in this project. Please read this information before deciding whether or not to take part. If you decide to participate, thank you. If you decide not to take part, thank you for considering my request.

\section{Who am I?}

My name is Camilla Angoro and I am a Master student in Development Studies programme at Victoria University of Wellington, New Zealand. This research project is work towards my master's thesis.

\section{What is the aim of the project?}

This project aims to understand the contributions of Australian Aid in supporting gender and women's empowerment in Oro Province of Papua New Guinea. This research has been approved by the Victoria University of Wellington Human Ethics Committee [approval number 24463].

\section{How can you help?}

If you agree to take part I will interview you at a venue of your choosing. I will ask you questions about gender programs in Papua New Guinea, and Oro province supported by Australian Aid and PNG Government. The interview will take approximately 30 minutes. I, Camilla, will audio record the interview. You can stop the interview at any time, without giving a reason. You can withdraw from the study by contacting me at any point before the $31^{\text {st }}$ of July, 2017. If you withdraw, the information you provided will be destroyed or returned to you.

\section{What will happen to the information you give?}

This research is confidential. This means that the researchers named below will be aware of your identity but the research data will be aggregated and your identity will not be disclosed in any reports, presentations, or public documentation. However, you should be aware that in small projects your identity might be obvious to others in your community.

Only my supervisors and I will read the notes or transcript of the interview. The interview transcripts, summaries and any recordings will be kept securely and destroyed 3 years after the research ends. 


\section{What will the project produce?}

The information from my research will be used in my Masters report.

\section{If you accept this invitation, what are your rights as a research participant?}

You do not have to accept this invitation if you don't want to. If you do decide to participate, you have the right to:

- $\quad$ choose not to answer any question;

- $\quad$ ask for the recorder to be turned off at any time during the interview;

- $\quad$ withdraw from the study before 31/07/2017;

- ask any questions about the study at any time;

- $\quad$ receive a copy of your interview recording (if it is recorded);

- $\quad$ read over and comment on a written summary of your interview;

- $\quad$ agree on another name for me to use rather than your real name;

- be able to read any reports of this research by emailing the researcher to request a copy.

If you have any questions or problems, who can you contact?

If you have any questions, either now or in the future, please feel free to contact either:

Student:

Name: Camilla Angoro

University email

\section{Supervisor:}

Name: Professor John Overton

address: Role: Director, Postgraduate Programme in Development Studies

School: Geography, Environment an Earth Sciences

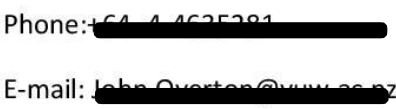

\section{Human Ethics Committee information}

If you have any concerns about the ethical conduct of the research you may contact the Victoria University HEC Convener: Associate Professor Susan Corbett. Email s telephone 


\title{
12. Information Sheet - Group 3 (This group did not take part in the interview due to their busy schedule).
}

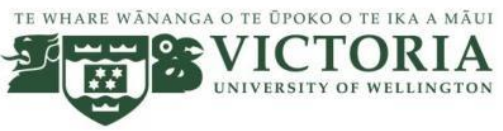 \\ The Decentralisation of Australian Aid's Gender Equality and Women's \\ Empowerment Strategy in Oro Province, Papua New Guinea \\ INFORMATION SHEET FOR PARTICIPANTS_LOCAL LEADERS
}

Thank you for your interest in this project. Please read this information before deciding whether or not to take part. If you decide to participate, thank you. If you decide not to take part, thank you for considering my request.

\section{Who am I?}

My name is Camilla Angoro and I am a Master student in Development Studies programme at Victoria University of Wellington, New Zealand. This research project is work towards my master's thesis.

\section{What is the aim of the project?}

This project aims to understand the contributions of Australian Aid in supporting gender and women' empowerment in Oro Province of Papua New Guinea.

This research has been approved by the Victoria University of Wellington Human Ethics Committee [approval number will be inserted when approval is given].

\section{How can you help?}

If you agree to take part, I will interview you at a venue of your choosing. I will ask you questions about gender programs in Papua New Guinea, and Oro province supported by Australian Aid and PNG Government. The interview will take approximately 30 minutes. I, Camilla, will audio record the interview. You can stop the interview at any time, without giving a reason. You can withdraw from the study by contacting me at any point before the $31^{\text {st }}$ of July, 2017. If you withdraw, the information you provided will be destroyed or returned to you.

\section{What will happen to the information you give?}

The research is not confidential, and you will be named in the final report.

Only my supervisors and I will read the notes or transcript of the interview. The interview transcripts, summaries and any recordings will be kept securely and destroyed 3 years after the research ends.

\section{What will the project produce?}




\section{If you accept this invitation, what are your rights as a research participant?}

You do not have to accept this invitation if you don't want to. If you do decide to participate, you have the right to:

- $\quad$ choose not to answer any question;

- $\quad$ ask for the recorder to be turned off at any time during the interview;

- withdraw from the study before 31/07/2017

- ask any questions about the study at any time;

- $\quad$ receive a copy of your interview recording (if it is recorded);

- $\quad$ read over and comment on a written summary of your interview;

- be able to read any reports of this research by emailing the researcher to request a copy.

If you have any questions or problems, who can you contact?

If you have any questions, either now or in the future, please feel free to contact either:

Student:

Name: Camilla Angoro

University email address:

anoorocaminmusumach

\section{Supervisor:}

Name: Professor John Overton

Role: Director, Postgraduate Programme in Development Studies

School: Geography, Environment an Earth Sciences

Phone

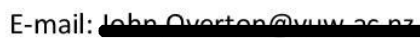

\section{Human Ethics Committee information}

If you have any concerns about the ethical conduct of the research you may contact the Victoria University HEC Convener: Associate Professor Susan Corbett. Email susan.corbett@vuw.ac.nz or telephone+64-4-463 5480. 


\title{
13. Information Sheet - Group 4 (English Version)
}

\author{
TE WHARE WÃNANGA TE OPOKO O TE IKA A Mãu \\ The Decentralisation of Australian Aid's Gender Equality and Women's \\ Empowerment Strategy in Oro Province, Papua New Guinea \\ INFORMATION SHEET FOR PARTICIPANTS_LOCAL WOMEN
}

Thank you for your interest in this project. Please read this information before deciding whether or not to take part. If you decide to participate, thank you. If you decide not to take part, thank you for considering my request.

\section{Who am I?}

My name is Camilla Angoro and I am a Master student in Development Studies programme at Victoria University of Wellington, New Zealand. This research project is work towards my master's thesis.

\section{What is the aim of the project?}

This project aims to understand the contributions of Australian Aid in supporting gender and women' empowerment in Oro Province of Papua New Guinea. This research has been approved by the Victoria University of Wellington Human Ethics Committee [approval number will be inserted when approval is given].

\section{How can you help?}

If you agree to take part I will interview you at a venue of your choosing. I will ask you questions about gender programs Oro province supported by Australian Aid and PNG Government. The interview will take approximately 30 minutes. I, Camilla, will audio record the interview. You can stop the interview at any time, without giving a reason. You can withdraw from the study by contacting me at any point before the $31^{\text {st }}$ of July, 2017. If you withdraw, the information you provided will be destroyed or returned to you.

\section{What will happen to the information you give?}

This research is confidential. This means that the researchers named below will be aware of your identity butyour identity will not be disclosed in any reports, presentations, or public documentation. However, you should be aware that in small projects your identity might be obvious to others in your community.

Only my supervisors and I will read the notes or transcript of the interview. The interview transcripts, summaries and any recordings will be kept securely and destroyed 3 years after the research ends. 
What will the project produce?

The information from my research will be used in my Master's report.

If you accept this invitation, what are your rights as a research participant?

You do not have to accept this invitation if you don't want to. If you do decide to participate, you have the right to:

- $\quad$ choose not to answer any question;

- $\quad$ ask for the recorder to be turned off at any time during the interview;

- $\quad$ withdraw from the study before 31/07/2017;

- ask any questions about the study at any time;

- $\quad$ receive a copy of your interview recording (if it is recorded);

- $\quad$ read over and comment on a written summary of your interview;

- $\quad$ agree on another name for me to use rather than your real name;

- be able to read any reports of this research by emailing the researcher to request a copy

If you have any questions or problems, who can you contact?

If you have any questions, either now or in the future, please feel free to contact either:

\section{Student:}

Name: Camilla Angoro

University email address:

\section{Supervisor:}

Name: Professor John Overton

Role: Director, Postgraduate Programme in Development Studies

School: Geography, Environment an Earth Sciences

Phone

E-mail:

\section{Human Ethics Committee information}

If you have any concerns about the ethical conduct of the research you may contact the Victoria University HEC Convener: Associate Professor Susan Corbett. Email

.nz or telephone 


\title{
14. Information Sheet - Group 4 (Tok Pisin Version)
}

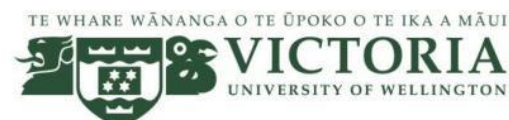

The Decentralisation of Australian Aid's Gender Equality and Women's Empowerment Strategy in Oro Province, Papua New Guinea

TOKSAVE LO OLAIN USAIT BAI STAP INSAIT LO WOK PAINIM AUT_OL MERI

Tenk yu tru lo laik blo yu lo displa projek. Ridim gut displa toksave bipo yu tingting lo stap insait lo wok painim aut blo mi. Sapos yu les, tenk yu tru lo takim taim lo harim askim blo mi.

Mi usait?

Nem blo mi em Camilla Angoro. Mi wanpla sumatin blo Victoria University, lo Development Studies programme. Displa wok painim aut, bai helpim mi lo raitim Master's thesis blo mi.

\section{Wok painim aut blo displa project?}

Displa wok painim aut bai try lo luksave lo ol halivim blo Australian Gavman lo said blo halivim ol meri lo yumi lo Oro province. Ethics Komiti blo Victoria University ibin givim tok orait lo mi mekim displa wok painim aut.

\section{Hau bai yu halivim mi?}

Sapos yu laik go pas lo displa wok painim aut, bai mi askim yu sampla askim lo said blo gender na wok blo ol mama na meri. Yumi bai toktok inap lo 30pla minit. Bai mi raitim ol toktok blo yu lo pepa. Yu ken stopim mi lo any taim, sapos yu les lo go pas lo displa toktok blo yumi. Sapos yu les olgeta lo toktok blo yu bai stap insait lo wok painimi aut, yu mas toksave lo mi bipo 31/07/17. Mi bai rausim olgeta toktok yu givim or givim bek lo yu.

\section{Wanem bai kamap lo ol toktok yu givim mi?}

Displa wok painim aut no nap toksave lo yu usait lo taim lo raitim ripot. Tasol lo liklik ol projeks lo komuniti, em bai klia liglig lo yu usait.

Tisa blo mi tasol bai save lo ol wok mi mekim na ol toktok mi kisim lo yupla. Olgeta toktok yu mekim lo mi bai mi lukautim gut na bai mi tromoi afta lo tripla yia.

Wok painim aut bai karim wanem kaikai?

Toktok yu givim, bai halivim mi lo raitim master's thesis ripot.

Raits blo yu lo displa wok painim aut? 
Yu no nid lo akceptim askim blo mi to go pas lo displa wok painim aut, tasol if yu laik halivim mi, yu gat rait lo:

- $\quad$ les lo ansarim ol askim;

- $\quad$ askim lo rekoda lo bai tanim op;

- $\quad$ Askim lo raus lo wok painim aut bipo lo 32/-7/17;

- $\quad$ Askim any askim lo taim blo wok painim aut;

- $\quad$ kisim tok alrait lo usim narapla nem, ino nem trutru blo yu;

Sapos yu gat sampla moa askim, yu ken contactim mipla?

Sapos yu gat sampla moa askim behain, contactim mi and tisa blo mi:

Student:

Name: Camilla Angoro

University email address:
Supervisor:

Name: Professor John Overton

Role: Director, Postgraduate Programme in Development Studies

School: Geography, Environment an Earth Sciences

Phone:

E-mail:

\section{Human Ethics Committee information}

If you have any concerns about the ethical conduct of the research you may contact the Victoria University HEC Convener: Associate Professor Susan Corbett. Email 


\title{
15. Generic interview question guide for each group
}

\author{
$=$ \\ The Decentralisation of Australian Aid's Gender Equality and Women's \\ Empowerment Strategy in Oro Province, Papua New Guinea
}

\section{INTERVIEW QUESTIONS/GUIDE}

There are four main groups that will be involved in the interviews. Below are themes that I will generate specific questions from while in the field.

\section{Group 1: Australian Aid Representatives}

Participants will be asked to talk about the following areas;

- Implementation of the Australian Aid Gender Equity and Women's Empowerment Strategy in Papua New Guinea

- Contributions to women's empowerment in Papua New Guinea from aid programs

- Practicalities of implementation of the Gender Strategy at sub-national levels

- Kind of support (projects, funding, etc) that is provided to Oro Province, and how much goes to women's empowerment.

\section{Group 2: Government Officials (National and Sub-national)}

There are four agencies/organisations in this group. Participants will be invited to discuss following topics;

- Department of Community Development representative

- Implementation of PNG Government's Gender Policies

- Collaboration with Australian Aid to implement gender related policies and plans

- Department of National Planning and Monitoring representative

- The coordination international aid in Papua New Guinea, specifically its movement into sub-national levels

- Department of Personnel Management representative

- Implementation of Gender Equality and Social Inclusion Policy (GESI) at subnational levels

- Oro Provincial Administration representative

- Women' empowerment and gender related initiatives done by the administration 
- Support received from Australian Aid

Group 3: Local Politicians from Oro Province

Interviewees will be cover similar issues as group two as well as these topics;

- Political support for women's empowerment in the province

- The movement and channels of aid flow into the province

- The support of Australian aid in the province

Group 4: Local Women's Group in Oro Province Participants will be asked on the following topics;

- Support from Australian Aid

- Contributions of the organisation/group towards women's empowerment

- Constraints/Issues in the work they do 